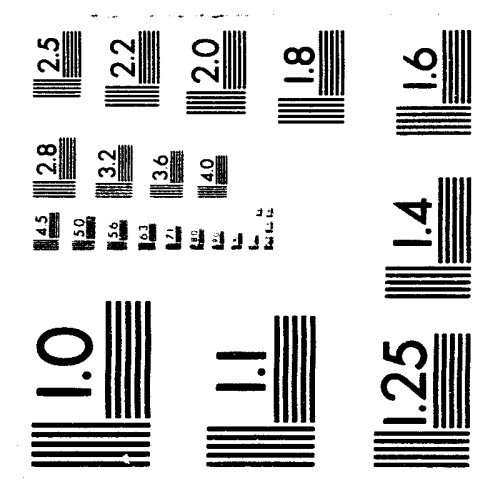






\title{
Facility Effluent Monitoring Plan for the Uranium Trioxide Facility
}

\author{
J. Lohrasbi \\ D. L. Johnson \\ Westinghouse Hanford Company \\ D. S. De Lorenzo \\ Los Alamos Technical Associates
}

Date Published

December 1993

Prepared for the U.S. Department of Energy Office of Environmental Restoration and Waste Management

\section{(2) Westinghouse P.O. Box 1970}

(W) Hanford Company Richland, Washington 99352

Hanford Operations and Engineering Contractor for the

U.S. Department of Energy under Contract DE.AC06-87RL10930 
Document Title: Facility Effluent Monitoring Plan for the Uranium Trioxide Facility

Prepared by:



$$
\frac{11-1-93}{\text { Date }}
$$

PUREX Surveillance Engineers

Prepared by:

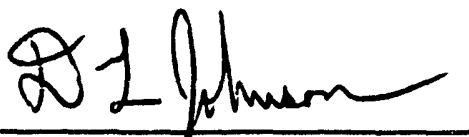

D. L. Johnson, Cognizant Engineer,

PUREX Surveiliance Engineers

C.D. Wollan

C. D. Wollam, Manager,

PUREX Surveillance Engineers

Davidal Shenford

Approved by:

Approved by:

Approved by:

Approved by:

D. D. Volkman, Manager,

Environmental Services Quality Assurance

TiRe.



D. H. Shuford, Acting Manager, $\mathrm{UO}_{3}$ Plant
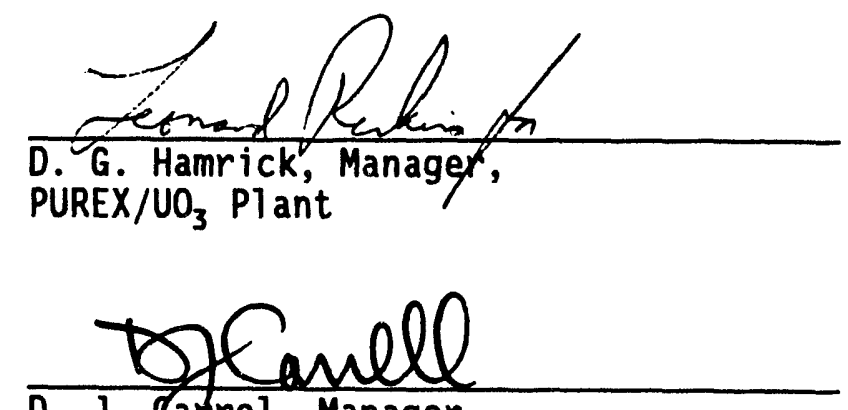

D. J. Grel, Manager, Regulatory Analysis

10Nor 93

Date

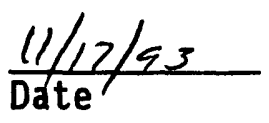

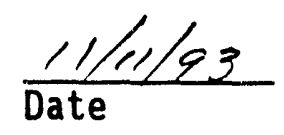

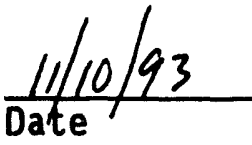

L. P. Diediker, Manager,

Effluent and Emission Monitoring

$\frac{11-11-93}{\text { Date }}$ 


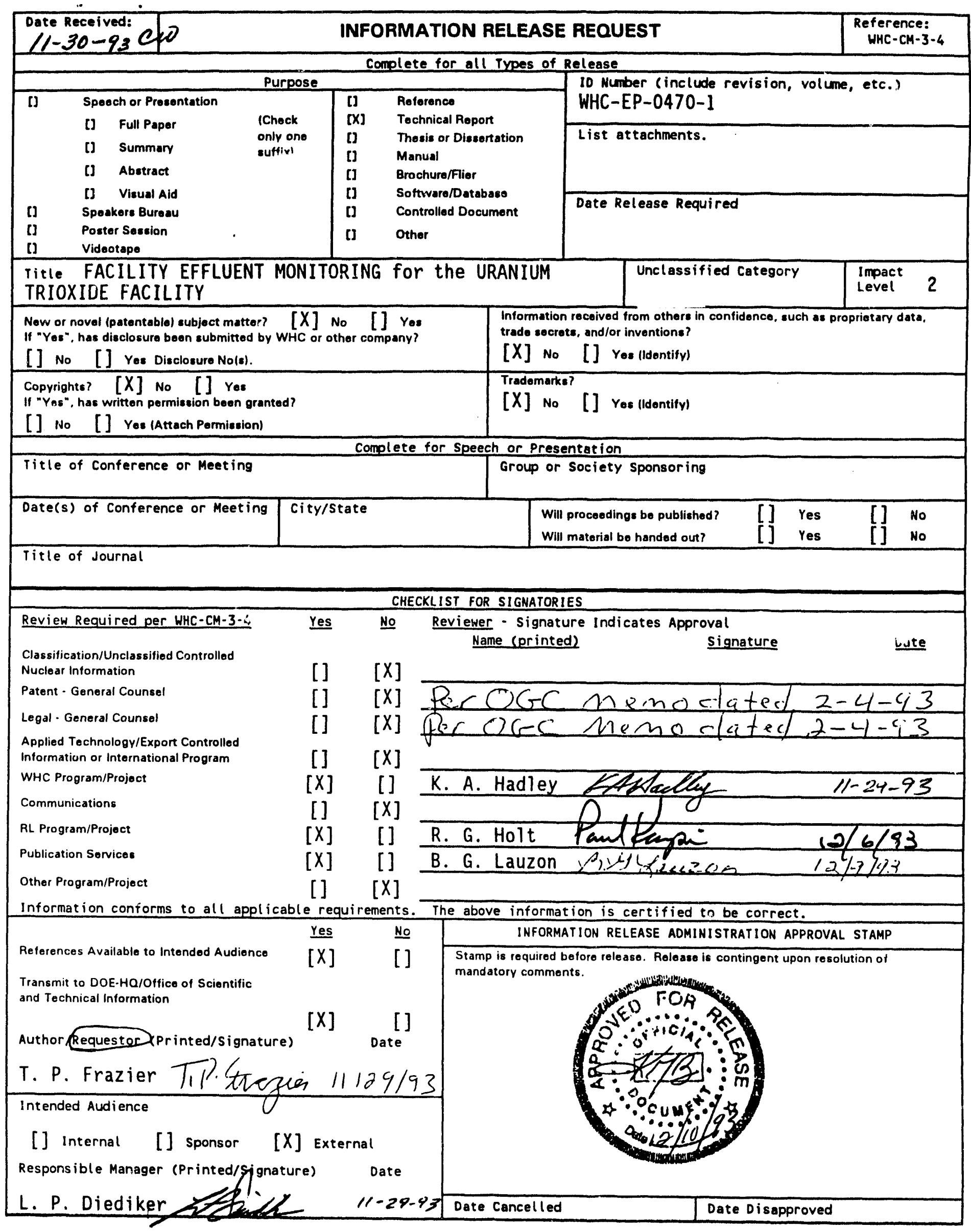


WHC-EP-0470-1

FACILITY EFFLUENT MONITORING PLAN FOR THE

URANIUM TRIOXIDE FACILITY

\begin{abstract}
A facility effluent monitoring plan is required by the U.S. Department of Energy in DOE Order 5400.1* for any operations that involve hazardous materials and radioactive substances that could impact employee or public safety or the environment. This document is prepared using the specific guidelines identified in A Guide for Preparing Hanford Site Facility Effluent Monitoring Plans, WHC-EP-0438-01**. This fac). ty effluent monitoring plan assesses effluent monitoring systems and evaluates whether they are adequate to ensure the public health and safety as specified in applicable federal, state, and local requirements.
\end{abstract}

This facility effluent monitoring plan shall ensure long-range integrity of the effluent monitoring systems by requiring an update whenever a new process or operation introduces new hazardous materials or significant radioactive materials. This document must be reviewed annually even if there are no operational changes, and it must be updated at a minimum of every three years.

*General Environmental Protection Program, DOE Order 5400.1, U.S. Department of Energy, Washington, D.C., 1988.

$\star \star A$ Guide for Preparing Hanford Site Facility Effluent Monitoring Plans, WHC-EP-0438-01, Westinghouse Hanford Company, Richland, Washington, 1992. 
WHC-EP-0470-1

This page intentionally left blank. 




1.1 POLICY . . . . . . . . . . . . . . . . . 1-1

1.2 PURPOSE . . . . . . . . . . . . . . . . . . 1-1

1.3 SCOPE ...................... . . 1-2

1.4 DISCUSSION .................. . . . 1-3

2.0 FACILITY DESCRIPTION . . . . . . . . . . . . . . 2-1

2.1 BRIEF FACILITY PHYSICAL DESCRIPTION . . . . . . . . . 2-1

2.1.1 $\mathrm{UO}_{3} \mathrm{Pl}$ ant Process Facilities . . . . . . . . . . . 2-1

2.1.2 Process Condensate Handling Facilities . . . . . . . 2-2

2.2 BRIEF PROCESS DESCRIPTION . . . . . . . . . . . . 2-2

2.3 IDENTIFICATION AND CHARACTERIZATION OF POTENTIAL

SOURCE TERMS .................... 2-3

2.3.1 Gaseous Effluents................. 2-3

2.3.2 $\mathrm{UO}_{3}$ Liquid Emissions . . . . . . . . . . . . . 2-4

3.0 APPLICABLE REGULATIONS . . . . . . . . . . . . . . . . . 3-1

3.1 U.S DEPARTMENT OF ENERGY ORDERS . . . . . . . . . . . . . . 3-1

3.1.1 U.S. Department of Energy Order 5400.1 . . . . . . . . 3-1

3.1.2 U.S. Department of Energy Order 5400.5 . . . . . . . . 3-1

3.2 FEDERAL REgULATIONS . . . . . . . . . . . . . . . . 3-1

3.2.1 Environmental Protection Agency Regulations on

National Emission Standards for Hazardous Air

Pollutants 40 Code of Federal Regulations 61 .... . 3-1

3.2.2 Reportable Quantities 40 Code of Federal

Regulations $302 . . . . . . . . . . .3-2$

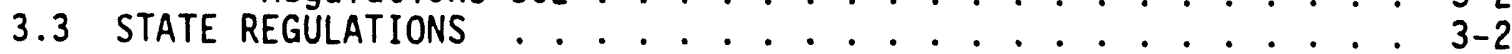

3.3.1 Radioactive Air Emissions Regulations........ 3-2

3.3.2 Groundwater Protection .............. 3-3

3.3.3 Dangerous Waste Regulations............ . 3-3

3.4 LOCAL REGULATIONS . . . . . . . . . . . . . . . . 3-3

3.4.1 Benton, Frankl in, and Walla Walla Counties

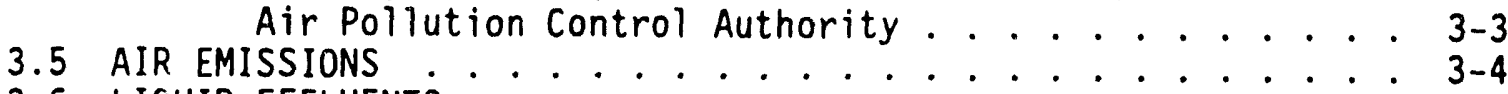

3.6 LIQUID EFFLUENTS . . . . . . . . . . . . . . . . . . . . . . . 3-5

4.0 IDENTIFICATION AND CHARACTERIZATION OF EFFLUENT STREAMS . . . . . . 4-1

4.1 IDENTIFICATION AND CHARACTERIZATION OF SOURCE TERMS

CONTRIBUTING TO EACH AIR EFFLUENT STREAM . . . . . . . . . . . 4-1

4.1.1 Discharge Descriptions . . . . . . . . . . . . . . . 4-1

4.1.2 Routine Operating Conditions . . . . . . . . . . . . 4-1

4.1.3 Upset Operating Conditions . . . . . . . . . . . . . 4-2

4.1.4 Dispersion Modeling . . . . . . . . . . . . . . . . . . 4-2

4.2 IDENTIFICATION AND CHARACTERIZATION OF SOURCE TERMS
CONTRIBUTING TO EACH WATER EFFLUENT STREAM . . . . . . . $4-4$

4.2.1 Discharge Descriptions .. . . . . . . . . . . . . . . . . . . 4-5

4.2.2 Rout ine Operating Conditions . . . . . . . . . . . . . . 4-5

4.2.3 Upset Operating Conditions . . . . . . . . . . . . . . 4-6

4.2.4 Liquid Effluent Criteria . . . . . . . . . . . . . . . . 4-7 


\section{CONTENTS (continued)}

5.0 EFFLUENT POINT OF DISCHARGE DESCRIPTION . . . . . . . . . . . 5-1

5.1 AIR EFFLUENTS ..................... . 5-1

5.1.1 296-U-4 Stack .................. . 5-1

5.1 .2 296-U-2 Stack .................. . 5-1

5.1.3 296-U-13 Stack ................. . 5-2

5.2 WATER EFFLUENTS ..................... . . . 5-2

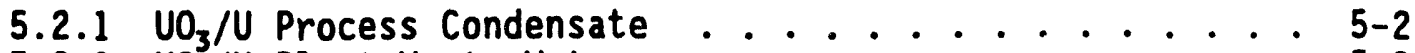

5.2.2 $\mathrm{UO}_{3} / \mathrm{U}$ Plant Waste Water .. . . . . . . . . . . . 5-3

6.0 EFFLUENT MONITORING/SAMPLING SYSTEM DESIGN CRITERIA . . . . . . . . 6-1

6.1 NEW FACILITIES ..................... . . 6-1

6.2 EXISTING FACILITIES . . . . . . . . . . . . . . . . 6-1

6.2.1 Airborne Effluent Sampling and Monitoring System
Design Criteria.... . 6-1

6.2.2 Liquid Effluent Sampling and Monitoring System

Design Criteria.............. . . 6-4

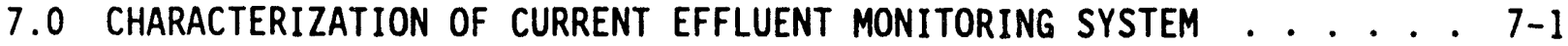

7.1 AIR EFFLUENT MONITORING SYSTEM DESCRIPTION AND

SPECIFICATIONS . . . . . . . . . . . . . . . . . . . . . . 7-1

7.1.1 296-U-4 Stack Instrumentation and Controls

Specifications ............. . . . . . . .

7.1.2 296-U-2 Stack Instrumentation and Controls

Specifications ............... . 7-2

7.1.3 296-U-13 Instrumentation and Controls

Specifications . . . . . . . . . . . . . 7-2

7.1.4 Air Effluent Monitoring Program . . . . . . . . . 7-3

7.2 LIQUID EFFLUENTS . . . . . . . . . . . . . . . . . . . . 7-4

7.2.1 Monitoring/Sampling Requirements .. . . . . . . . . 7-4

7.2.2 Process Condensate Effluent Monitoring/Sampling

System .................. . 7-5

7.2.3 Effluent Monitoring/Sampling System . . . . . . . . 7-5

8.0 HISTORICAL MONITORING/SAMPLING DATA FOR EFFLUENT STREAMS . . . . . 8-1

8.1 AIR EFFLUENTS ...................... . . . . . . . .

8.1.1 Normal Conditions................. . . 8-1

8.1.2 Upset Conditions . . . . . . . . . . . . . . . . 8-2

8.2 WATER EFFLUENTS ........................ . . . . 8 .

8.2.1 Normal Conditions.................. . . 8-2

8.2.2 Upset Conditions . . . . . . . . . . . . . . 8-2

9.0 SAMPLE ANALYSIS . . . . . . . . . . . . . . . . . . . . 9-1

9.1 ANALYTICAL LABORATORY AND PROCEDURES ................ . . . . $9-1$

9.2 SAMPLE AND DATA CHAIN OF CUSTODY . . . . . . . . . . . . . . . 9 -5

10.0 NOTIFICATION AND REPORTING REQUIREMENTS . . . . . . . . . . . . . . . 10-1

10.1 OCCURRENCE CATEGORIZATION, NOTIFICATION, AND REPORTING . . . . 10-1

10.1.1 Occurrence Identification and Immediate

Response .. . . . . . . . . . . . . . 10-1

10.1.2 0ccurrence Categorization ........... . . 10-2 


\section{CONTENTS (continued)}

10.2 OCCURRENCE CATEGORIZATION .............. 10-2

10.2.1 Radioactive Releases ........... . 10-2

10.2.2 Release of Hazardous Substances/Regulated

Pollutants/0il .............. 10-3

10.2.3 Discovery of Hazardous Material Contamination

Due to DOE Operations .......... 10-4

10.2.4 Agreement/Compliance Activities . . . . . . . . 10-5

10.2.5 Ecological Resources ............ 10-5

10.3 FEDERAL REQUIREMENTS ............. . . . . . . . . . . .

10.3.1 Resource Conservation and Recovery Act of 1976 . . . 10-6

10.3.2 Comprehensive Environmental Response, Compensation and Liability Act of $1980 \ldots$. . . . . . . . . .

10.3.3 National Emission Standards for Hazardous Air Pollutants . . . . . . . . . . . . 10-6

10.4 STATE REQUIREMENTS . . . . . . . . . . . . . . . . . . .

10.4.1 Generator Reporting . . . . . . . . . . . 10-6

10.4.2 Facility Reporting . . . . . . . . . . . 10-6

10.5 U.S. DEPARTMENT OF ENERGY REQUIREMENTS ........ . . . . . . . .

10.5.1 U.S. Department of Energy Order 5400.1, Chapter II

General Environmental Protection Program -

Notification and Reports ....... . . 10-7

10.5.2 U.S. Department of Energy Order 5484.1 Environmental Protection, Safety and Health Protection Information Reporting Requirements . . . . . . . . . 10-7

11.0 INTERFACE WITH THE OPERATIONAL ENVIRONMENTAL MONITORING

PROGRAM

11 . DESCRIPTION $\ldots \ldots \ldots \ldots \ldots \ldots \ldots$

11.2 PURPOSE $\ldots \ldots \ldots \ldots \ldots \ldots \ldots$

11.3 BASIS . . . . . . . . . . . . . . . . . . . . . . . 11-2

11.4 MEDIA SAMPLED AND ANALYSES PERFORMED .............. . . $11-3$

11.5 LOCATIONS .......................... . . . . . . . . . . . . .

11.6 PROGRAM REVIEW ......................... . . . . . . . . . . . .

11.7 SAMPLER DESIGN . . . . . . . . . . . . . . . . . . . . . . . . $11-4$

11.8 COMMUNICATION . . . . . . . . . . . . . . . . . . . . . . . . . . $11-4$

11.9 REPORTS .......................... . . . . . . . . . . .



12.1 PURPOSE . . . . . . . . . . . . . . . . . . . . . . . . . . $12-1$

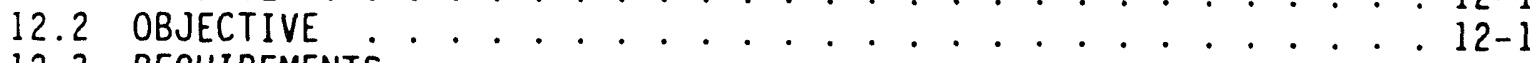

12.3 REQUIREMENTS . . . . . . . . . . . . . . . . . . . . . . $12-1$

13.0 INTERNAL AND EXTERNAL PLAN REVIEW.............. . . . . . . . 


\section{CONTENTS (continued)}

14.0 COMPLIANCE ASSESSMENT . . . . . . . . . . . . . 14-1

14.1 COMPLIANCE ASSESSMENT ............. . . . . . . . . .

14.1.1 Comparison of Instrument Specifications with

Required Standards ............ . . 14-1

14.1.2 Comparison of Instrument Specifications with

Monitoring Criteria ........... . . 14-1

14.1.3 Comparison of Instrument Specifications with Effluent Characteristics .......... 14-1

14.1.4 Comparison of Projected Effluent Characteristics with Historical Data .......... . . 14-2

14.1.5 Comparison of Effluent Monitoring Capabilities



14.3 SYSTEM UPGRADES REQUIRED FOR COMPLIANCE ......... . . 14-2

15.0 SUMMARY AND CONCLUSIONS . . . . . . . . . . . . 15-1

16.0 ATTACHMENTS . . . . . . . . . . . . . . . 16-1

16.1 REFERENCES . . . . . . . . . . . . . . . . . . . . .

16.2 STATE APPROVED LAND DISPOSAL STRUCTURE ACCEPTANCE

CRITERIA . . . . . . . . . . . . . . . 16-6 
WHC-EP-0470-1

\section{LIST OF FIGURES}

2-1 UO $\mathrm{UP}_{3}$ Plant Site Map . . . . . . . . . . . . . . . 2-6

2-2 $\mathrm{UO}_{3}$ Plant and Ancillary Facilities . . . . . . . . . . . 2-7

2-3 224-U Building . . . . . . . . . . . . . . . . . 2-8

2-4 224-UA Bui ding . . . . . . . . . . . . . . . . . . 2-9

2-5 Powder Handling Off-Gas System . . . . . . . . . . . . 2-10

2-6 296-U-4 Contributing Stream . . . . . . . . . . . . . . 2-11

2-7 Load-Out Hood Exhaust System . . . . . . . . . . . . . 2-12

4-1 Contributors to $\mathrm{UO}_{3} \mathrm{Pl}$ ant Process Condensate . . . . . . . . . 4-8

4-2 $\mathrm{UO}_{3} / \mathrm{U}$ Plant Waste Water Routing . . . . . . . . . . . . . 4-9 


\section{LIST OF TABLES}

3-1 Applicable Regulations and Standards . . . . . . . . . . 3-6

3-2 Groundwater Quality Criteria . . . . . . . . . . . . 3-9

4-1 UO $\mathrm{UO}_{3}$ Stack Exhaust Data . . . . . . . . . . . . . . 4-10

4-2 CAP-88 Unit Dose Factors for the Offsite Hypothetical Maximally Exposed Individual Affected by Radionuclide Air Emissions

from the 200 Area .................... . . 4-11

4-3 $\mathrm{UO}_{3}$ Radionuclide Emissions from Exhaust Stacks for 1992 . . . . . . 4-12

4-4 Doses to the Maximally Exposed Individual for 1992. . . . . . . 4-12

4-5 Individual Radionuclide Doses to the Maximally Exposed

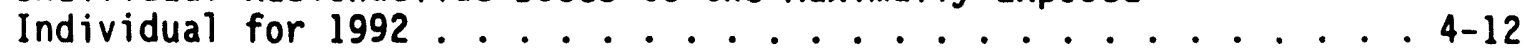

4-6 Doses to the Maximally Exposed Individual from an Unmitigated

Release......................... 4-13

4-7 Individual Radionuclide Doses to the Maximally Exposed

Individual from an Unmitigated Release . . . . . . . . . . . 4-13

4-8 Summary of $\mathrm{UO}_{3}$ Plant Liquid Effluents............. . 4-14

7-1 Bag Filter Differential Pressure Control Settings and Alarm

Points ....................... . . . . . . 6

7-2 Comparison of $\mathrm{UO}_{3} / \mathrm{U}$ Plant Effluent Qualities and State Approved

Land Disposal Structure Acceptance Criteria . . . . . . . . . 7-7

8-1 Stack 296-U-2 Gaseous Radioactive Effluent Release Data. . . . . 8-3

8-2 Stack 296-U-04 Gaseous Radioactive Effluent Emissions Data . . . 8-3

8-3 Stack 296-U-13 Gaseous Radioactive Effluent Emissions Data . . . 8-4

8-4a $\mathrm{UO}_{3} \mathrm{Pl}$ ant to 216-U-14 Ditch, 200 West Area (H102), Calendar

Year 1990 ......................... . . 8-4

8-4b Radionuclides in $\mathrm{UO}_{3} \mathrm{Plant}$ to 216-U-14 Ditch, 200 West Area

(H102) in 1991 ................... 8-5

8-4C Radionuclides in $\mathrm{UO}_{3}$ Plant Discharges (207-U) to 216-U-14 Ditch, 200 West Area $\left(\mathrm{H}_{102}\right)$ in 1992 ................ 8-5

8-5 Radionuclides in Uranium-0xide Plant Process Condensate Discharges $(U-17)$, to 216-U-17 Crib, 200 West Area, in 1992 (H126).... 8-6

16-1 Acceptance Criteria for 200 Area Treated Effluent Disposal Facility 


\section{LIST OF TERMS}

ANSI

APCA

ASTM

BAT

CAM

CERCLA

CFR

$\mathrm{CHI} / \mathrm{Q}$

DCG

DF

DOE

DP

EDE

Ecology

EMP

EOC

EPA

FEMP

HEPA

HVAC

ICRP

$M C L$

MEI

$\mathrm{M} / \mathrm{S}$

MOU

MSDS

NESHAP

NPDES

PAO

PDD

$\mathrm{ppb}$

PNL

PSD

PUREX

QAPjP

QAPP

RCRA

$\mathrm{RL}$

SALDS

SARA

SCD

SDWA

SQA

TEDF

TLD

TSD

UNH

$\mathrm{UO}_{3}$

$\mathrm{U} / \mathrm{UPW}$
American National Standards Institute

Air Pollution Control Authority

American Society for Testing and Materials

best available technology

continuous air monitoring

Comprehensive Environmental Response, Compensation, and Liability Act of 1980

Code of Federal Regulations

air concentration per unit source release

derived concentration guide

decontamination or treatment factor

U.S. Department of Energy

differential pressure

effective dose equivalent

Washington State Department of Ecology

environmental monitoring plan

emergency operations center

U.S. Environmental Protection Agency

Facility Effluent Monitoring Plan

high-efficiency particulate air (filter)

heating, ventilation, and air conditioning

International Commission on Radiation Protection

maximum concentration level

maximally exposed individual

monitoring/sampling

memorandum of understanding

Material Safety Data Sheet

National Emission Standards for Hazardous Air

Pollutants

National Pollutant Discharge Elimination System

Public Affairs Office

process distillate discharge

parts per billion

Pacific Northwest Laboratory

prevention of significant deterioration

Plutonium-Uranium Extraction (Plant)

Quality Assurance Project Plan

Quality Assurance Program Plan

Resource Conservation and Recovery Act of 1976

U.S. Department of Energy, Field Office, Richland

state approved land disposal structure

Superfund Amendments and Reauthorization Act of 1986

steam condensate

Safe Drinking Water Act

software quality assurance

Treated Effluent Disposal Facility

thermal luminescent dosimeter

treatment, storage, and disposal

uranyl nitrate hexahydrate

uranium trioxide

$\mathrm{UO}_{3} / \mathrm{U}$ Plant 
WHC-EP-0470-1

\section{LIST OF TERMS (continued)}

USC

WAC

WHC

WPCA
United States Code

Washington State Administrative Code

Westinghouse Hanford Company

Water Pollution Control Act 
WHC-EP-0470-1

METRIC CONVERSION CHART

\begin{tabular}{|c|c|c|}
\hline \multicolumn{3}{|c|}{ INTO METRIC } \\
\hline If you know & Multiply by & To get \\
\hline \multicolumn{3}{|c|}{ Length } \\
\hline inches & 2.54 & centimeters \\
\hline feet & 30.48 & centimeters \\
\hline miles & 1.6093 & kilometers \\
\hline \multicolumn{3}{|c|}{ Volume } \\
\hline gallons & 3.786 & liters \\
\hline cubic feet & 0.02832 & cubic meters \\
\hline \multicolumn{3}{|c|}{ Temperature } \\
\hline Fahrenheit & $\begin{array}{l}\text { Subtract } 32 \text { then } \\
\text { multiply by } 5 / 9 \text { ths }\end{array}$ & Celsius \\
\hline \multicolumn{3}{|c|}{ Pressure } \\
\hline inches water & 1.87 & $\mathrm{mmHg}$ \\
\hline \multicolumn{3}{|c|}{ OUT OF METRIC } \\
\hline \multicolumn{3}{|c|}{ Length } \\
\hline centimeters & 0.3937 & inches \\
\hline meters & 3.28 & feet \\
\hline kilometers & 1.6093 & miles \\
\hline \multicolumn{3}{|c|}{ Volume } \\
\hline milliliters & $1.247 \times 10^{-3}$ & cubic feet \\
\hline liters & 0.264 & gallons \\
\hline cubic meters & 35.31 & cubic feet \\
\hline \multicolumn{3}{|c|}{ Temperature } \\
\hline Celsius & $\begin{array}{l}\text { Multiply by } 9 / 5 \text { ths, then } \\
\text { add } 32\end{array}$ & Fahrenheit \\
\hline \multicolumn{3}{|c|}{ Weight } \\
\hline grams & 28.35 & ounces \\
\hline
\end{tabular}


WHC-EP-0470-1

This page intentionally left blank. 


\subsection{INTRODUCTION}

The U.S. Department of Energy (DOE) Order 5400.1 (DOE 1991a) requires Facility Effluent Monitoring Plans (FEMP), for DOE facilities that have gaseous and/or liquid effluents. Only effluent sources that release significant pollutants or hazardous materials are included in this order; sanitary sewer and exhausts from air heating or cooling equipment are exempt. The effluent monitoring will be adequate to determine whether the public and environment are adequately protected during operations and whether operations are in compliance with DOE orders and other applicable federal, state, and local standards and requirements. It is also DOE policy that effluent monitoring programs meet high standards of quality and credibility.

The $\mathrm{UO}_{3}$ Plant is located in the 200 West Area of the Hairford Site, in the south central region of Washington State. The plant consists of two primary processing buildings and several ancillary facilities. The $\mathrm{UO}_{3} \mathrm{Pl}$ ant has completed its processing mission and is now in transition to a long-term shutdown mode. The purpose of the $\mathrm{UO}_{3}$ Plant was to receive uranyl nitrate hexahydrate (UNH) from the Plutonium-Uranium Extraction (PUREX) Plant, concentrate it, convert the UNH to uranium trioxide $\left(\mathrm{UO}_{3}\right)$ powder by calcination and package it for offsite shipment. There are two liquid discharges, three gaseous exhaust stacks, and several building exhausters that are active during the transition to shutdown. When the plant shutdown is completed, there will be no liquid or gaseous discharges from $\mathrm{UO}_{3} \mathrm{Plant}_{\text {. }}$

\subsection{POLICY}

It is the policy of DOE and Westinghouse Hanford Company (WHC) to conduct effluent monitoring that is adequate to determine whether the public and environment are adequately protected during DOE operations and whether operations are in compliance with DOE and other applicable federal, state, and local radiation and nonradioactive and hazardous materials standards and requirements. It is also DOE and DOE-contractor policy that effluent monitoring programs meet high standards of quality and credibility.

\subsection{PURPOSE}

This plan is to fulfill the requirements of DOE Order 5400.1 (DOE 1991a) for a FEMP for each facility that contain hazardous materials that could impact public and employee safety and the environment. The following are the three goals of this FEMP.

1. Identify and evaluate the gaseous and liquid effluents from the $\mathrm{UO}_{3}$ Plant through characterization.

2. Determine the discharge criteria for gaseous and liquid effluents.

3. Establish a program to ensure compliance with those discharge criteria. 


\subsection{SCOPE}

This document includes program plans for characterization and monitoring radioactive and nonradioactive hazardous materials discharged from the $\mathrm{UO}_{3}$ Plant. This plan includes complete documentation for gaseous and liquid effluent monitoring systems for both radioactive and nonradioactive hazardous pollutants that could be discharged under routine and/or upset conditions.

The following specific sections detail how the FEMP is implemented and structured.

\begin{tabular}{|c|c|}
\hline Section & Scope \\
\hline 2.0 & $\begin{array}{l}\text { This brief facility description } \\
\text { summarizes the processes that produce } \\
\text { the effluents and couples them with a } \\
\text { listing of effluents. }\end{array}$ \\
\hline 3.0 & $\begin{array}{l}\text { This section is a summary of DOE } \\
\text { orders and federal and state } \\
\text { regulations that establish FEMP } \\
\text { requirements and discharge criteria. }\end{array}$ \\
\hline 4.0 & $\begin{array}{l}\text { Each gaseous and liquid effluent is } \\
\text { characterized. Routine and upset } \\
\text { conditions are described. The } \\
\text { discharge criteria are developed and } \\
\text { listed. }\end{array}$ \\
\hline 5.0 & $\begin{array}{l}\text { Discharge points for each effluent } \\
\text { are described. }\end{array}$ \\
\hline 6.0 & $\begin{array}{l}\text { The design criteria of the } \\
\text { monitoring/sampling }(M / S) \text { system are } \\
\text { listed for air and water effluents. }\end{array}$ \\
\hline 7.0 & $\begin{array}{l}\text { Instrument descriptions and } \\
\text { specifications of the effluent } \\
\text { monitoring system are given. }\end{array}$ \\
\hline 8.0 & $\begin{array}{l}\text { Appropriate historical monitoring and } \\
\text { sampling data are summarized. }\end{array}$ \\
\hline 9.0 & $\begin{array}{l}\text { Analytical requirements are listed } \\
\text { and coupled with sampling and sample } \\
\text { handling procedures. }\end{array}$ \\
\hline 10.0 & $\begin{array}{l}\text { Notification and reporting } \\
\text { requirements for routine and } \\
\text { environmental occurrence reports and } \\
\text { procedural changes are listed. }\end{array}$ \\
\hline 11.0 & $\begin{array}{l}\text { This section provides the interface } \\
\text { of the FEMP with the operational } \\
\text { environmental surveillance program. }\end{array}$ \\
\hline
\end{tabular}


Section

12.0

13.0

14.0

15.0

16.0
Scope

The Quality Assurance Plan governing field activities, laboratory analysis, and recordkeeping is stated. Audits are also covered.

Internal and external FEMP review requirements are given.

Compliance assessment is summarized.

This section includes a summary and list of conclusions.

References used in the FEMP are listed.

\subsection{DISCUSSION}

The characterization of the radioactive and nonradioactive constituents in each of the effluent stream provides the underlying rationale for the sampling and monitoring programs. The method of characterization discussed in this plan identifies potential pollutants at the point of generation and tracks the constituents in effluent streams as they move from their generation point to the point of discharge.

During this movement, engineered barriers and/or emission control systems that reduce the levels of constituents in the effluent stream are encountered. These barriers or controls can exist in various locations within each effluent stream. The effectiveness of each control device is measured as a decontamination or treatment factor (DF). The DF can be determined by projection, experiment, testing, operational data, or vendor specifications. Whenever projections are made, a sufficient degree of conservativism is used to ensure a high level of confidence in the resulting projections.

Emission controls between the point of generation and the discharge point are not to be considered when determining whether a FEMP should be developed for a specific facility or for performing a compliance assessment. The controls are to be considered when assessing the types and amounts of a pollutant at the discharge point.

As pollutants in each stream are tracked along the stream, the concentrations or quantities of constituents at the point of discharge should be consistent with the estimates of contributor stream concentrations and quantities and the DF assigned to the various emission control systems.

Tracking the fate of all possible constituents in the effluent stream provides defensible documentation that all appropriate constituents are being monitored and sampled at the point of discharge. This does not mean that effluent streams should be monitored between individual emission control systems. 
Characterization of dangerous waste pollutants at the point of generation is required by Title 40 Code of Federal Regulations (CFR) 261.3(b) (EPA 1989a). This requirement only applies to dangerous waste as defined by the Washington Administrative Code (WAC). Other regulations, such as 40 CFR 61, Subpart $H$ (EPA 1991C), provide guidance on the adequacy of effluent monitoring. However, all potential pollutants should be characterized at the point of generation to: (1) assess the preventive capabilities of engineered and administrative barriers and the consequences of an upset release due to failure of one of these barriers, and (2) verify that the sampling and monitoring programs address all pertinent constituents at the point of discharge. 


\subsection{FACILITY DESCRIPTION}

This section presents a brief facility and process description of the $\mathrm{UO}_{3} \mathrm{Plant}$. These descriptions include the following:

- Location and physical layout of the process facility

- General description of the present, past, and future activities of the process

- Identity of waste streams.

Specific information on the gaseous and liquid effluents are provided in Section 4.0, Identification and Characterization of Effluent Streams.

\subsection{BRIEF FACILITY PHYSICAL DESCRIPTION}

The $\mathrm{UO}_{3} \mathrm{Plant}$ is located in the 200 West Area of the Hanford Site (Figure 2-1) which is located in the south-central region of Washington State. The plant consists of two primary processing facilities, Buildings 224-U and 224-UA, and several ancillary facilities as shown in Figure 2-2. Principal buildings and structures are described below.

\subsection{1 $\mathrm{UO}_{3}$ Plant Process Facilities}

2.1.1.1 Building 224-U. Building 224-U is a concrete walled structure constructed in 1944. The building is $44 \mathrm{~m}$ (144 ft.) long and $28 \mathrm{~m}$ ( $92 \mathrm{ft}$.) wide, with the roof $12 \mathrm{~m}(39 \mathrm{ft}$.) above grade. The primary functions of this building were to receive UNH solutions from the PUREX Plant and to concentrate them for processing in Building 224-UA. In addition, a nitric acid recirculation loop system from Building 224-U scrubbed the calciner off-gas in Building 224-UA to capture and dissolve entrained $\mathrm{VO}_{3}$ fines.

The 224-U Building is divided along its length into a canyon side, containing the process equipment for concentrating the UNH, and a three-floored gallery, containing offices, piping, and operating areas. Details of the building are shown in Figure 2-3.

2.1.1.2 Building 224-UA. Building 224-UA is immedict, y south of 224-U. It is a steel-walled and framed building constructed in 1957 . The building is $29 \mathrm{~m}$ (95 ft.) long and $16 \mathrm{~m}(52 \mathrm{ft}$.) wide. Its principal roof is $8.5 \mathrm{~m}$ $(28 \mathrm{ft}$.$) above grade, al though a processing tower extends to 15.5 \mathrm{~m}(51 \mathrm{ft}$.) above grade. The primary purposes of this building were to convert UNH from Building 224-U to $\mathrm{UO}_{3}$ powder though calcination and to package it for offsite shipment. Calciner off-gas was routed to the nitric acid recovery system in Building 224-U. 
The 224-UA Building has two floors; the equipment for the calcining process is on the upper floor, while the powder pickup bins and the wet particulate scrubbers are on the ground floor. Figure 2-4 shows details of this building.

2.1.1.3 203-U Enclosure. The 203-U enclosure is a roofless, concrete-diked, process chemical tank, storage area $24 \mathrm{~m}$ (79 ft.) long and $13.7 \mathrm{~m}$ (45 ft.) wide. The 203-U enclosure stored feed UNH from PUREX, recycled UNH for return to the PUREX Plant, process condensate, and potassium hydroxide. Any solutions collected in the 203-U enclosure sump were transferred to Building 224-U for processing.

2.1.1.4 Backpad Area. The backpad area between 224-U, 203-UX, 224-UA, and 203-U contains additional tankage and piping connecting the main process buildings. The concrete-diked 203-UX enclosures in the backpad area adjacent to the 224-U Building contain tanks that stored concentrated UNH from the 224-U Building in preparation for processing in 224-UA. Any rainfall or uranium-bearing solutions collected in sumps in the potentially contaminated backpad area are routed to Building 224-U for processing.

2.1.1.5 211-U Tank Farm. The 211-U Tank Farm located to the north of the $\mathrm{UO}_{3}$ Facility, contains four storage tanks (including one that is maintained as a spare) where nitric acid recovered at the $\mathrm{UO}_{3}$ Plant was staged for rail shipment to PUREX. Sumps in the 211-U Area drain to the $\mathrm{UO}_{3} \mathrm{Pl}$ ant waste water stream. There is no connection from this facility to the $\mathrm{UO}_{3}$ Plant Process Condensate Stream.

2.1.1.6 Retired Facilities. Former process and laboratory Buildings 221-U, 271-U, and 222-U, and other tanks at 211-U (formerly associated with 221-U), are no longer in operation. These retired facilities are not directly associated with the $\mathrm{UO}_{3} \mathrm{Pl}$ ant, but rainwater runoff and HVAC (heatingventilation-air conditioning) condensates from those buildings drain to the $\mathrm{UO}_{3} \mathrm{Pl}$ ant waste water system. These buildings are located generally North of $224-U$.

\subsubsection{Process Condensate Handling Facilities}

The $\mathrm{UO}_{3} \mathrm{Plant}$ Process Condensate Stream originates in off-gas condensers in Building 224-U. These condensers process contributor streams from throughout the $\mathrm{UO}_{3} \mathrm{Plant}$. The process condensate from the condensers drains to a surge tank ( $T K-X-37)$ in $203-U$. The process condensate is neutralized in Building 224-U and is discharged to the 216-U-17 Crib Plant. Redundant $\mathrm{pH}$ probes, transmitters, alarm switches, and strip chart recorders monitor the $\mathrm{pH}$ of the process condensate at a location just before exiting the 224-U Building.

\subsection{BRIEF PROCESS DESCRIPTION}

The principal operational mode for the $\mathrm{UO}_{3}$ Plant was UNH calcination. During the calcination mode, $\mathrm{UO}_{3}$ operations concentrate a 60 percent UNH 
solution to a 100 percent UNH solution and then calcines the 100 percent UNH solution into $\mathrm{UO}_{3}$ powder. The nitrogen oxides liberated during calcining are converted to nitric acid for reuse at PUREX.

The $\mathrm{UO}_{3}$ facility is in the process of transitioning to shutdown. Once in shutdown mode, no processing activities will occur. There will be no liquid or gaseous effluent streams when the transition to shutdown is completed.

\subsection{IDENTIFICATION AND CHARACTERIZATION OF POTENTIAL SOURCE TERMS}

Source terms for effluents from the $\mathrm{UO}_{3}$ facility depend on the building or process they originate from and whether the plant is in calcination or shutdown mode. This document has been written to address the near-future status of the $\mathrm{UO}_{3}$ facility in shutdown mode.

\subsubsection{Gaseous Effluents}

There are three exhaust stacks and seven roof exhausts that contribute to the gaseous effluents from the $\mathrm{UO}_{3} \mathrm{Plant}$. The seven roof exhd'sters are considered to be a source of air effluent because they are from room or corridor exhausts that are noncontaminated, normally occupied, or accessed areas. The three air exhaust stacks that may be active until the $\mathrm{UO}_{3} \mathrm{Plant}$ is in shutdown are 296-U-2, 296-U-4, and 296-U-13. Of these, 296-U-2 and 296-U-13 are active only as needed during terminal clean-out and maintenance-related activities. Table 4-1, in Section 4.0, summarizes $\mathrm{UO}_{3}$ stack physical and exhaust data. The following characterizations of these stacks are taken primarily from the Effluent Monitoring Plan for $\mathrm{UO}_{3}$ Plant Gaseous Effluents, SD-CP-EMP-003 (WHC 1989a).

2.3.1.1 296-U-2 Stack. The 296-U-2 Stack is located on the 224-UA roof and serves to exhausts air from the powder handling system. Air for this system originates in the pickup bins. Air is subsequently routed through parallel cyclone separators, primary bag filters, secondary bag filters (both bag filters separate essentially all the $\mathrm{UO}_{3}$ powder from the air), prefilters, and high-efficiency particulate air (HEPA) filters before reaching the exhausters (Figure 2-5).

2.3.1.2 296-U-4 Stack. The 296-U-4 Stack system, located on the 224-U roof, exhausts unfiltered cooled air from the process off-gas system. Until plant shutdown, this off-gas is composed of process tank vents and vapor from the C-2 tank concentrator. Flow through the stack is supplied by a $1251 \mathrm{~b} / \mathrm{in}^{2}$ (gauge) steam jet, and a 2,200 $\mathrm{ft}^{3} / \mathrm{min}$ air blower. The EB-3 and ED-3 condensers then knock out most condensables before discharge. A fiber mist eliminator installed in 1991 minimizes carryover of entrained contaminants from the UNH concentrators.

The 296-U-4 Stack has the following three contributing streams: (1) the acid absorber exhaust (during plant operation, only), (2) th: $E-B-3$ condenser exhaust, and (3) the cell air exhaust from the $X-14$ blower (Figure 2-6). 
The primary source for the acid absorbcr exhaust system is the calciner off-gas, which has high concentrations of $\mathrm{NO}_{\mathrm{x}}$ fumes. Most of the tanks vented though the vessel vent system are also part of this contributing stream.

The primary sources for the ED-3 condenser exhaust system are the UNH concentrators. Several tanks are also vented though this exhaust system.

Exhaust air from B-cell is the major contributor to the 296-U-4 stream. The primary purpose of this stream is to provide high gas velocities though the stack to propel the $\mathrm{NO}_{\mathrm{x}}$ fumes away from workers.

2.3.1.3 296-U-13 Stack. The 296-U-13 Stack located on the 224-UA roof is a single-pass air exhaust system. This system exhausts filtered air from the $\mathrm{UO}_{3}$ powder loadout hood. The filters consist of 80 percent efficient prefilters and HEPA filters (Figure 2-7). The 296-U-13 Stack has no other contributing streams. The stack's sole purpose is to exhaust air from the powder load-out hood.

\subsection{2 $\mathrm{UO}_{3}$ Liquid Emissions}

There are two liquid waste streams at the $\mathrm{UO}_{3} \mathrm{Plant:}$ process condensate and plant waste water.

\subsubsection{Process Condensate. The process condensate consists almost entirely} of the following streams:

- Condensate formed from the cooling of process off-gas streams in either of two ve:ssel vent condensers

- Raw water used to maintain minimum flows to the acid absorber during processing

- Phosphoric acid and potassium hydroxide used to perform elementary neutralization.

Entrainment or condensed volatiles may introduce hazardous chemicals or radionuclides into the stream.

An automatic batch neutralization system controls the discharge pH of the process condensate effluent. During shutdown operation, process condensate rates are low enough, two gallons per minute, to allow batchwise analysis for radionuclides and hazardous chemicals before release. Figure 4-1 details the contributors to the $\mathrm{UO}_{3} \mathrm{Pl}$ ant Process Condensate.

2.3.2.2 Plant Waste Water. The plant waste water discharge consists almost entirely of raw water, taken from the Columbia River, or sanitary water used for cooling in condensers and compressors. Building and tank heaters also contribute small flows to the stream. The plant waste water stream is designed to be an uncontaminated stream. Except for off-normal conditions such as catastrophic equipment failure, none of the contributing sources comes directly in contact with any process fiuids. The only chemicals added to the waste water stream are residues from the desiccant air dryer and water treatment chemicals used in the HVAC air washer. The concentrations of the 
constituents in the desiccants (potassium carbonate, sodium nitrate, and urea) and water treatinent chemicals are non-toxic under Washington State Dangerous Waste Regulations, Washington Administrative Code (WAC) 173-303 (WAC 1991a).

The $\mathrm{UO}_{3} \mathrm{Plant}$ waste water stream routinely discharges through either section of the two-section 207-U Retention Basin and then into the 216-U-14 Ditch. Detection of hazardous chemicals or of the very low radionuclide content is accomplished through analysis of periodic samples. Figure 4-2 shows the $\mathrm{UO}_{3} \mathrm{Plant}$ waste water routing. 
Figure 2-1. $\mathrm{UO}_{3}$ Plant Site Map.
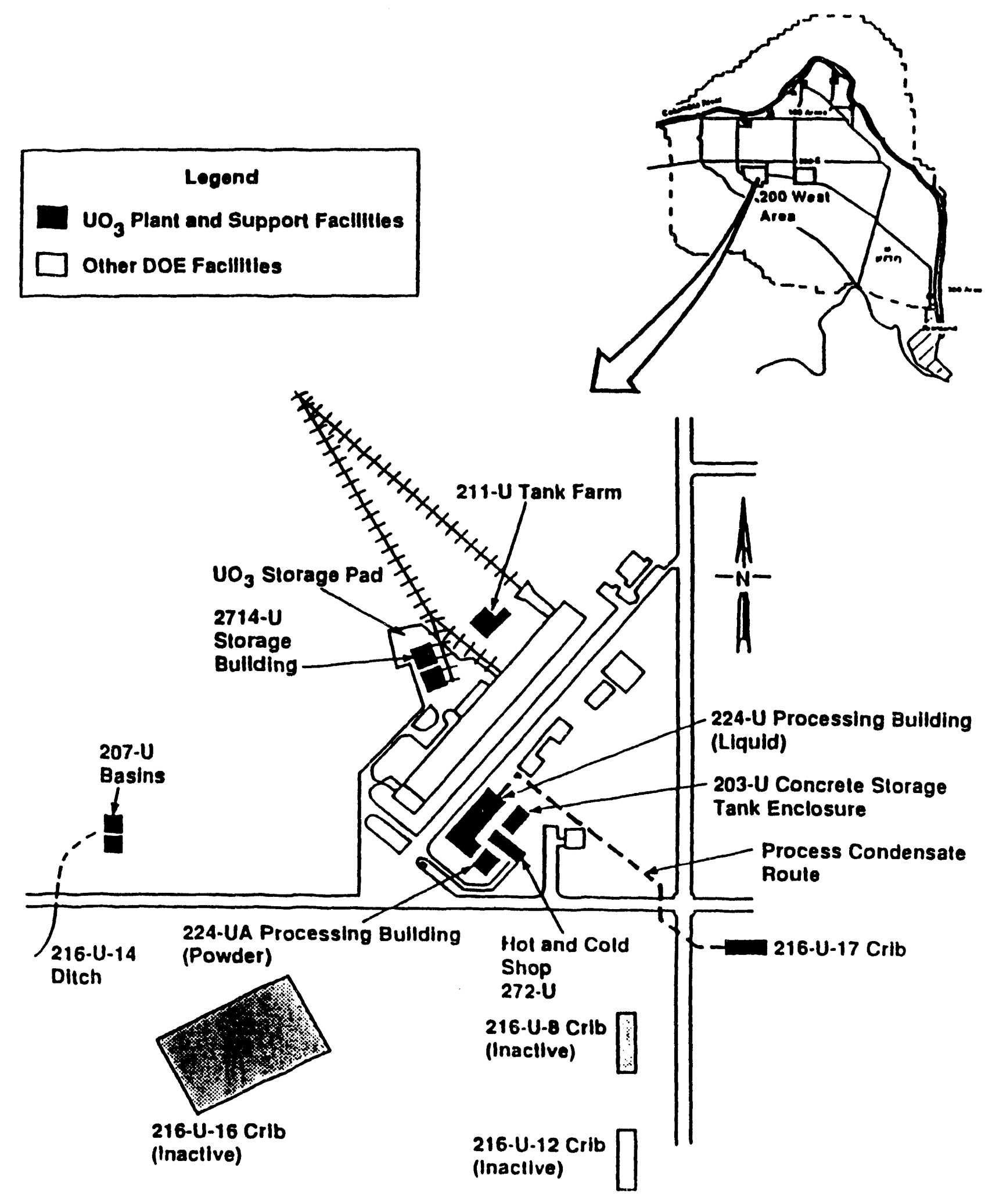
WHC-EP-0470-1

Figure 2-2. $\mathrm{UO}_{3}$ Plant and Ancillary Facilities.

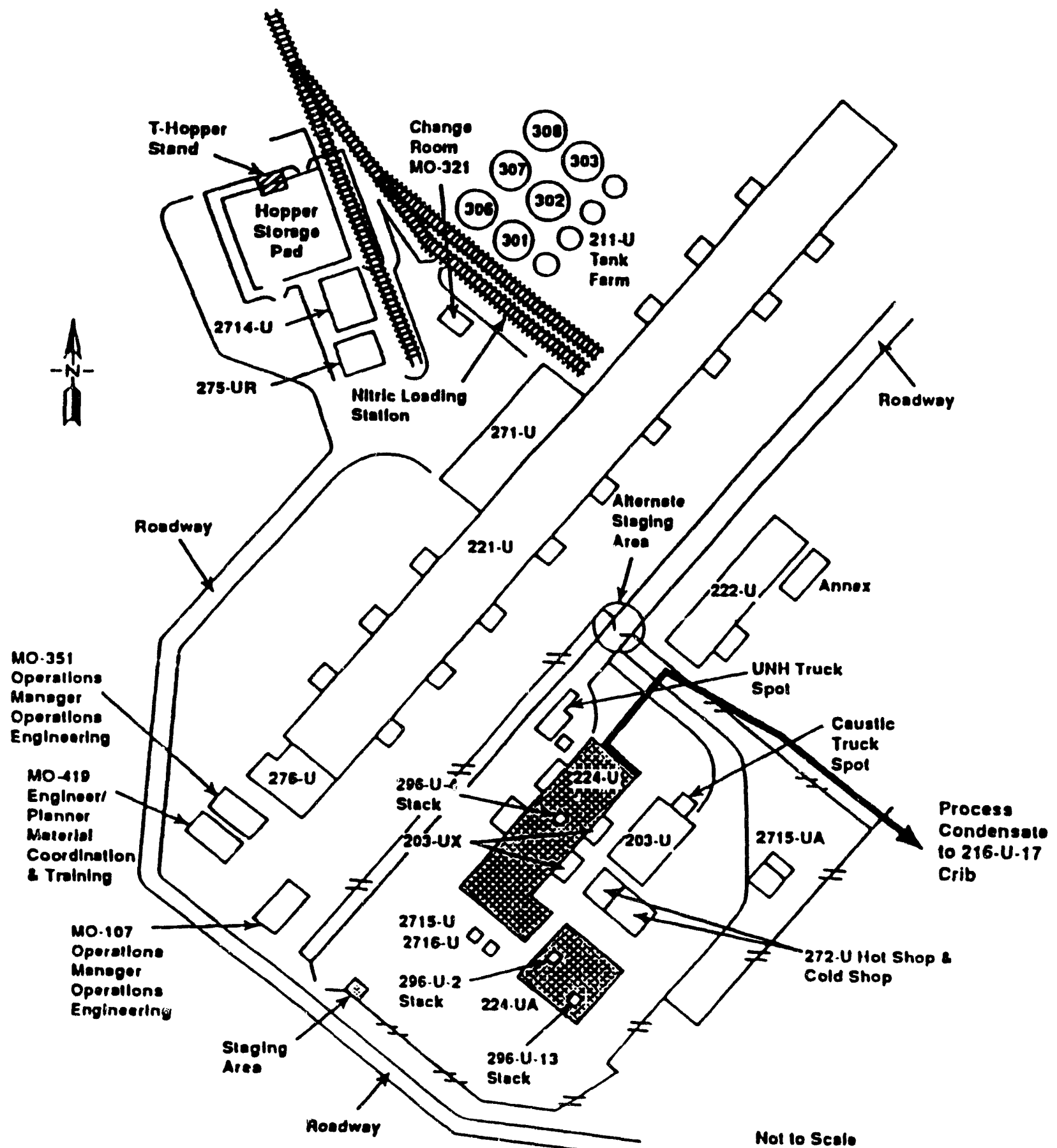


Figure 2-3. 224-U Building.



Socond Floor Level



Ground Floor Level 
Figure 2-4. 224-UA Building.

Figure 2-5. Powder Handling Off-Gas System.




WHC-EP-0470-1

Figure 2-6. 296-U-4 Contributing Stream.

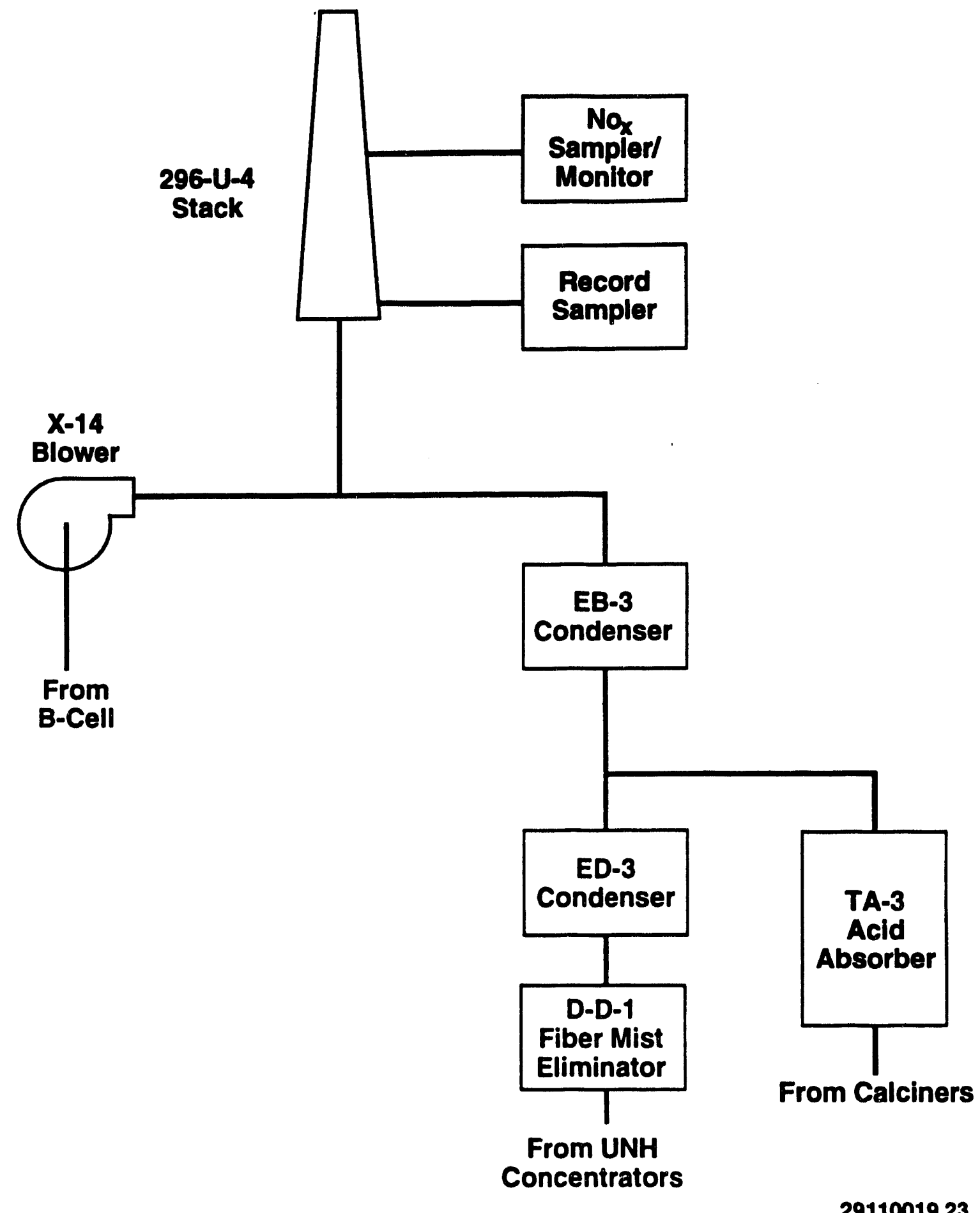


Figure 2-7. Load-Out Hood Exhaust System.

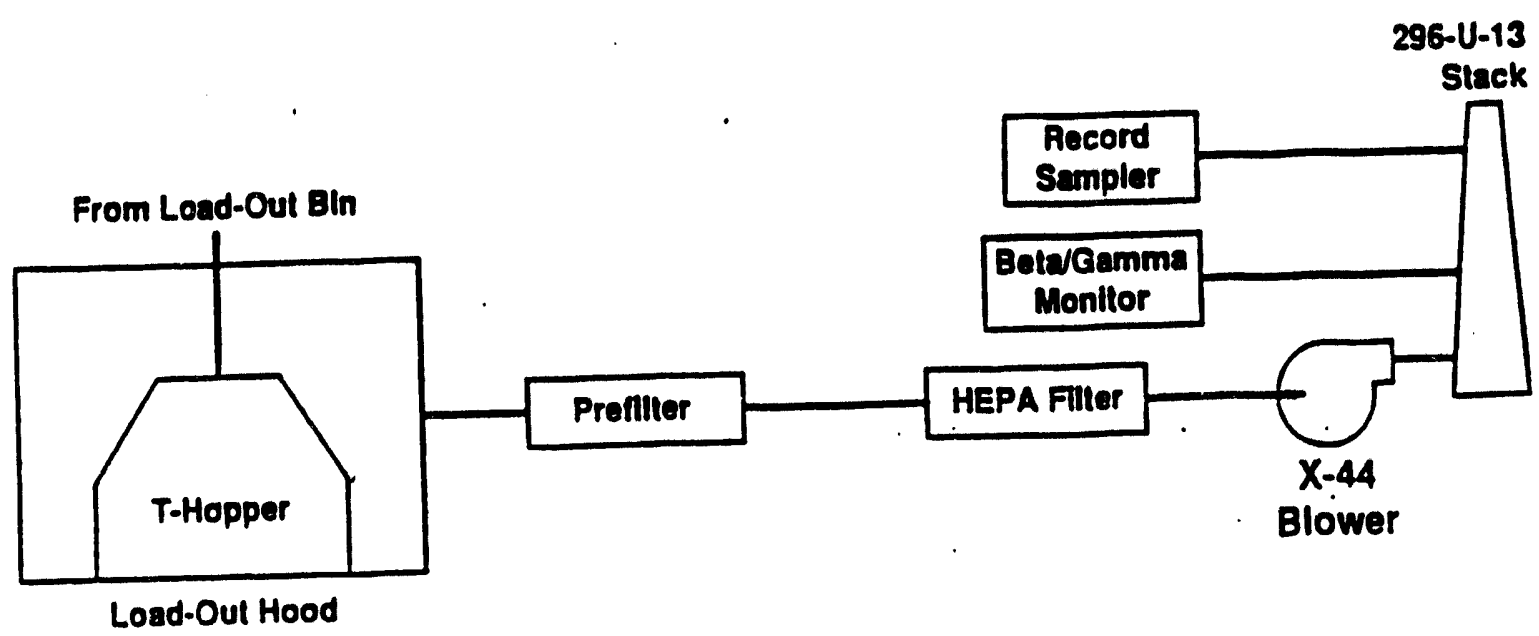




\subsection{APPLICABLE REGULATIONS}

Conditions and requirements for monitoring existing or potential releases of radioactive and other chemicals to the environment are contained in DOE orders and federal, state, and local laws and regulations. Table 3-1 gives a brief summary of the regulations and standards applicable to this FEMP.

\subsection{U.S DEPARTMENT OF ENERGY ORDERS}

\subsubsection{U.S. Department of Energy Order 5400.1}

The DOE Order 5400.1, General Environmental Protection Program (DOE 1991a), requires a written environmental monitoring plan for each site, facility, or process that uses, generates, releases, or manages significant pollutants or hazardous materials. The pian must include the rationale and design criteria for the monitoring program, as well as describe the extent and frequency of the monitoring analysis. The plan also must contain Quality Assurance (QA) requirements, program implementation procedures, directions for preparation and implementation of reports, and directions for identification and discussion of effluent monitoring and environmental surveillance.

The effluent monitoring portion of the plan must verify compliance with applicable regulations and DOE orders. It also should evaluate the effectiveness of treatment; identify potential environmental problems; evaluate the need for remedial action or mitigation measures; support permit revision and/or reissuance; and detect, characterize, and report unplanned releases.

\subsubsection{U.S. Department of Energy Order 5400.5}

The DOE Order 5400.5 (DOE 1990a) requires a monitoring plan that complies with the requirements of DOE Order 5400.1. Compliance with the requirements of DOE Order 5400.5 may be demonstrated based on calculations from monitoring and surveillance programs information.

\subsection{FEDERAL REGULATIONS}

\subsubsection{Environmental Protection Agency Regulations on National Emission Standards for Hazardous Air Pollutants 40 Code of Federal Regulations 61}

Subpart $H$, "National Emission Standards for Emissions of Radionuclides Other Than Radon from Department of Energy Facilities, " establishes exposure limits and monitoring requirements. The exposure limits, for members of the public, from radionuclide emissions is an effective dose equivalent (EDE) not to exceed $10 \mathrm{mrem} / \mathrm{yr}$. Compliance with this standard is measured by calculating the highest EDE where a person resides or abides using an EPA approved method. 
Emissions of radionuclides must be measured at all release points that have a potential to discharge radionuclides into the air in quantities that could cause an EDE in excess of 1 percent of the standard. If the EDE caused by all emissions is less than 1 percent of the standard the facility is exempt from the EPA monitoring requirements. All radionuclides that could contribute greater than 10 percent of the potential EDE for a release point shall be measured individually. With prior EPA approval, DOE may determine these emissions through al ternative procedures. For other release points that have a potential to release radionuclides into the air, periodic confirmatory measurements shall be made to verify low emissions.

To determine whether a release point is subject to emission measurement requirements, it is necessary to evaluate the potential for radionuclide emissions for that release point. In evaluating the potential of a release point to discharge radionuclides into the air, the estimated radionuclide release rates shall be based on the discharge of the effluent stream that would result if all pollution control equipment did not exist, but the facility operations were otherwise normal.

Subpart $H$ of 40 CFR 61 (EPA 1991a) also states that effluent streams shall be directly monitored continuously with an in-line detector or representative samples of the effluent stream shall be withdrawn continuously from the sampling site following the guidance presented in American National Standards Institute (ANSI) N13.1 (ANSI 1969). The requirements for continuous sampling are applicable to batch processes when the unit is in operation. Periodic sampling (grab samples) may be used only with EPA's prior approval. Such approval may be granted in cases where continuous sampling is not practical and radionuclide emission rates are relatively constant. In such cases, grab samples shall be collected with sufficient frequency to provide a representative sample of the emissions.

\subsubsection{Reportable Quantities 40 Code of Federal Regulations 302}

The regulations in 40 CFR 302 (EPA 1991b) designate hazardous substances and identify reportable quantities and notification requirements for releases of these hazardous substances under the Comprehensive Environmental Response, Compensation, and Liability Act (CERCLA) of 1980 and the Clean Water Act.

Any unpermitted release of any of these designated hazardous substances must be reported. Therefore, if the possibility exists for a facility to release any of the designated substances, waste streams must be monitored for their presence and monitoring practices must be provided in a FEMP.

\subsection{STATE REGULATIONS}

\subsubsection{Radioactive Air Emissions Regulations}

Althoug: WAC 173-480 (WAC 1991a) establishes a $25 \mathrm{mrem} / \mathrm{yr}$ effective dose equivalent for public exposure to radionuclide emissions, facilities must comply with the most restrictive of federal, state or local law. Therefore, the exposur: limit that must be complied with is $10 \mathrm{mrem} / \mathrm{yr}$; however, 
compliance is calculated at the point of maximum annual air concentration in an unrestricted area where any member of the public may be located (fence boundary).

The WAC 246-247, Radiation Protection Air Emissions (WAC 1991b), specified new source review, notification, registration, and permitting requirements associated with any source of radioactive airborne emissions in Washington State, including those on the Hanford Site. One requirement listed in WAC 246-27 is the semi-annual (twice yearly) reporting of emissions from each registered stack or vent onsite. By agreement with the Washington State Department of Health, only annual reporting is required.

\subsubsection{Groundwater Protection}

Radionuclides are defined as hazardous air pollutants, so they also will be construed to be hazardous in liquid effluent, without any specific 1 isting of individual radionuclides as a hazardous substance under water pollution control laws.

The Water Quality Standards For Groundwaters of the State of Washington (WAC 1987) protect groundwater to the level of drinking water standards. These standards limit exposures to gross alpha, gross beta, tritium, ${ }^{90} \mathrm{Sr}$, and 226. ${ }^{228} \mathrm{Ra}$ (Table 3-2). For radionuclides that are not specifically listed, exposures are limited by the federal standard to an effective dose equivalent not to exceed $4 \mathrm{mrem} / \mathrm{yr}$.

\subsubsection{Dangerous Waste Regulations}

Any release of a dangerous waste or hazardous substance [as designated by Washington (State) Administration Code (WAC) (WAC 1991a) to the environment, except permitted releases, must be reported. Waste streams that have the potential to contain dangerous waste constituents must be monitored accordingly.

\subsection{LOCAL REGULATIONS}

\subsubsection{Benton, Frankl in, and Walla Walla Counties Air Pollution Control Authority}

The local air pollution control authority has jurisdiction over all air emissions except radionuclide emissions in the Benton, Franklin, and Walla Walla county areas, including the Hanford Site. Currently, there are no local standards more restrictive than the previously mentioned state and ederal limits; therefore state and federal standards apply. 


\subsection{AIR EMISSIONS}

The DOE Order 5400.5 (DOE 1990a) provides requirements for the monitoring of radioactive and nonradioactive airborne effluents from DOE facilities at the Hanford Site. This order states that DOE-controlled facilities must comply with 40 CFR 61 (EPA 1991a).

Additional EPA requirements on hazardous substances are contained in 40 CFR Part 302.A. This regulation provides information on reportable quantities of nonradioactive hazardous substances. Unlisted hazardous substances designated by 40 CFR Part 302.4 are regulated in accordance with the EPA toxicity of the contaminant.

In Washington State, airborne effluents are regulated by the Department of Ecology through regulations in the WAC, Title 173, Chapters 173-400 through 173-490, as amendad, pursuant to the Washington Clean Air Act (RCW, Title 70, Public Health and Safety Chapter 94, as amended). General regulations for air pollution sources are presented in WAC 173-400, including emission standards for sources emitting hazardous air pollutants found in WAC 173-400-075.

The WAC 246-247, Radiation Protection Air Emissions (WAC 1991b), specifies new source review, notification, registration, and permitting requirements associated with any source of radioactive air emissions in Washington State, including those on the Hanford Site.

The WAC 173-480, Ambient Radionuclides (WAC 1991c), defines maximum allowable levels for radionuclides in the ambient air and defines required levels for control of emissions.

While both the WAC 246-247 and 173-480 list outdated maximum EDE standards, each contains a caveat stating that a more stringent federal standards take precedence over the EDE standard specified by the WAC.

Therefore, each effectively endorses the $10 \mathrm{mrem} / \mathrm{hr}$ EDE standard of $40 \mathrm{CFR} 61$, Subpart $H$.

In Washington State, airborne effluents are regulated by the Washington Clean Air Act of 1967. General regulations for air pollution sources are presented in WAC 173-400, including emission standards for sources emitting hazardous air pollutants in WAC 173-400-075. New sources for toxic air pollutants are presented in WAC 173-460. State regulations pertaining specifically to radioactive airborne effluents are found in WAC 246-247 and WAC 173-480, and are more restrictive in most cases than the Federal requirements.

Regulations, including DOE orders, state that DOE facilities must comply with the requirements set forth in the National Emission Standards for Hazardous Air Pollutants (NESHAP). Other regulations [e.g., 40 CFR 52, "Approval and Promulgation of Implementation Plans" (EPA 199lc); and DOE Orders 5400.1 (DOE 1991a), 5400.5 (DOE 1990a), DOE/EH-0173T (DOE 1991), and 5484.1 (DOE 1983)] state that DOE facilities must comply with the applicable requirements set forth in the Clear Air Act. 


\subsection{LIQUID EFFLUENTS}

Requirements limiting the exposure of the public to radioactive materials from DOE-controlled activities through the drinking water pathway are presented in DOE Order 5400.5, Chapter II, Paragraph 1.d. The radiological criteria of the public community drinking water standards of 40 CFR Part 141 , "National Interim Primary Drinking Waste Regulations" (EPA 1991d), are applicable to Steam and Water Utilities Operation 200 East and West Operations as the providers of potable water to the site under the Safe Drinking Water Act. It is the policy of DOE to provide an equivalent level of protection for all persons consuming water from a drinking water supply operated by, or for, the DOE. These systems shall not cause any persons consuming the water to receive an EDE greater than $4 \mathrm{mrem} / \mathrm{yr}$, excluding naturally occurring radionuclides. In addition, DOE facility operators shall ensure that the liquid effluents from DOE activities shall not cause private or public drinking water systems downstream of the facility discharge to exceed the drinking water radiological limits of 40 CFR Part 141.

Depending on where a liquid effluent (waste water) is discharged, certain regulations apply. These regulations are implemented through issuance of permits by federal, state, and/or local agencies. It is the responsibility of the facility, through the DOE Richland Field office (RL), to apply for the permit appropriate to the effluent being discharged. Before applying for any permits, the applicant must know the source of waste water discharges and where the waste water is being discharged to. The following regulations apply based on where the waste water is discharged.

1. The 40 CFR 261(4)(b)(6) (EPA 1989a) provides a hazardous waste exclusion for fly ash, bottom ash, slag waste, and flue gas emissions control waste generated primarily from combustion of gas or other fossil fuel.

2. Washington State controls discharges to groundwater and surface water of the state, under WAC 173-216 (WAC 1991a), and issues permits for such discharges. A permit of this type would be necessary for any discharges to land that could infiltrate to groundwater.

Each type of discharge permit identified will typically contain discharge limitations and monitoring requirements. However, the limitations and monitoring requirements will vary depending on the source and type of waste water being discharged. For instance, discharges to a publicly owned treatment works will be subject to pretreatment standards based on the production process that generated the waste water for those processes categorized by the EPA. Categorical processes are identified in 40 CFR 401-471 (EPA 1991e). Specific limitations, monitoring, and reporting requirements have been promulgated for each categorical process. In addition to EPA's requirements, the state and local waste water treatment agencies may impose additional limitations, monitoring, and reporting requirements. 


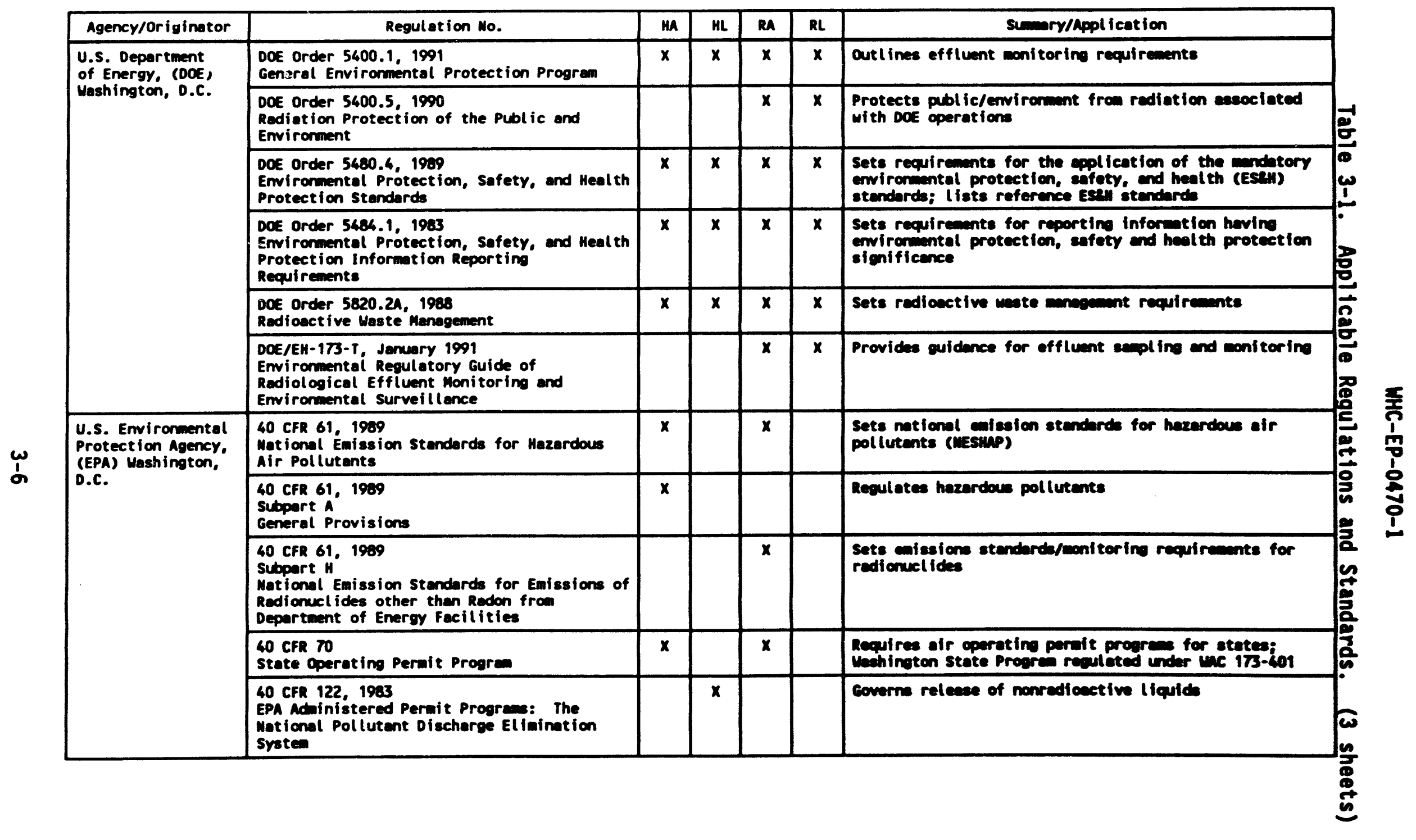




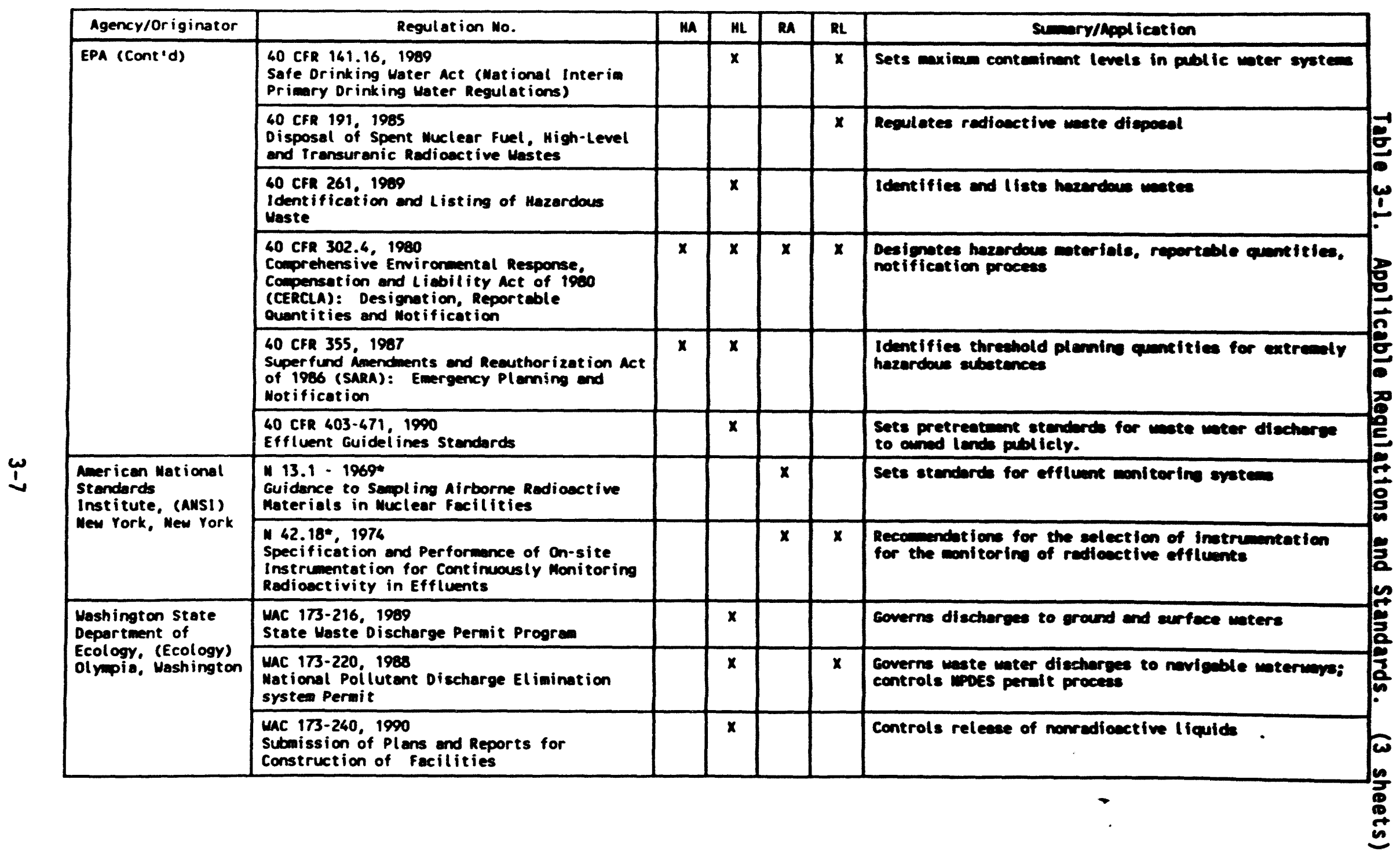




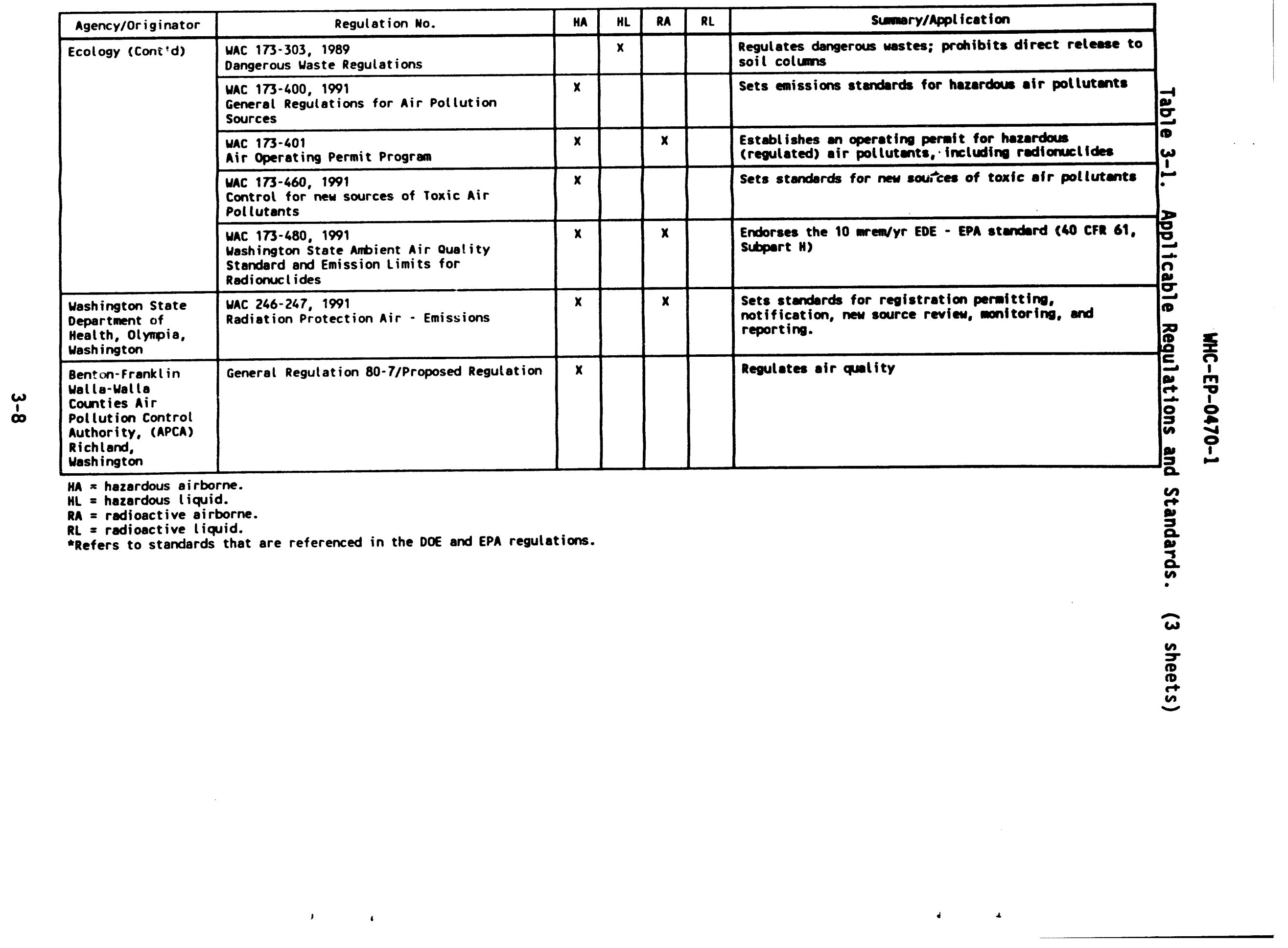


WHC-EP-0470-1

Table 3-2. Groundwater Quality Criteria. (5 shoets)

\begin{tabular}{|c|c|c|}
\hline \multicolumn{3}{|c|}{ A. Primary Contaminants } \\
\hline Contaminant & \multicolumn{2}{|c|}{ Criterion } \\
\hline Barium & 1.0 & $\mathrm{mg} / \mathrm{L}$ \\
\hline Cadmium" & 0.01 & $\mathrm{mg} / \mathrm{L}$ \\
\hline Chromium & 0.05 & $\mathrm{mg} / \mathrm{L}$ \\
\hline Lead" & 0.05 & $\mathrm{mg} / \mathrm{L}$ \\
\hline Mercury" & 0.002 & $\mathrm{mg} / \mathrm{L}$ \\
\hline Selenium" & 0.01 & $\mathrm{mg} / \mathrm{L}$ \\
\hline Silver & 0.05 & $\mathrm{mg} / \mathrm{L}$ \\
\hline Fluoride & 4 & $\mathrm{mg} / \mathrm{L}$ \\
\hline Nitrate (as N) & 10 & $\mathrm{mg} / \mathrm{L}$ \\
\hline Endrin & 0.0002 & $\mathrm{mg} / \mathrm{L}$ \\
\hline Methoxychlor & 0.1 & $\mathrm{mg} / \mathrm{L}$ \\
\hline 1,1,1-Trichloroethane & 0.20 & $\mathrm{mg} / \mathrm{L}$ \\
\hline $2-40$ & 0.10 & $\mathrm{mg} / \mathrm{L}$ \\
\hline 2,4,5-TP Silvex & 0.01 & $\mathrm{mg} / \mathrm{L}$ \\
\hline Total Coliform Bacteria & $1 / 100$ & $\overline{\mathrm{mL}}$ \\
\hline \multicolumn{3}{|c|}{ B. Secondard Contaminants } \\
\hline Contaminant & Crite & \\
\hline Copper & 1.0 & $\mathrm{mg} / \mathrm{L}$ \\
\hline Iron $^{\circ}$ & 0.30 & $\mathrm{mg} / \mathrm{L}$ \\
\hline Manganese" & 0.05 & $\mathrm{mg} / \mathrm{L}$ \\
\hline Zinc & 5.0 & $\mathrm{mg} / \mathrm{L}$ \\
\hline Chloride & 250 & $\mathrm{mg} / \mathrm{L}$ \\
\hline Sulfate & 250 & $\mathrm{mg} / \mathrm{L}$ \\
\hline Total Dissolved Solids & 500 & $\mathrm{mg} / \mathrm{L}$ \\
\hline Foaming Agents & 0.5 & $\mathrm{mg} / \mathrm{L}$ \\
\hline $\mathrm{pH}$ & $6.5-8.5$ & \\
\hline Corro.ivity & noncorrosive & \\
\hline
\end{tabular}


Table 3-2. Groundwater Quality Criteria. (5 sheets)

\begin{tabular}{|c|c|c|}
\hline \multicolumn{3}{|c|}{ B. Secondard Contaminants (Cont'd) } \\
\hline \multirow[t]{2}{*}{ Contaminant } & \multicolumn{2}{|c|}{ Criterion } \\
\hline & 15 color units & \\
\hline Odor & $\begin{array}{l}3 \text { threshold } \\
\text { odor units }\end{array}$ & \\
\hline \multicolumn{3}{|c|}{ C. Radionuclides } \\
\hline Contaminant & \multicolumn{2}{|c|}{ Criterion } \\
\hline Gross Alpha Particle Activity & 15 & $\mathrm{pCi} / \mathrm{L}$ \\
\hline \multicolumn{3}{|l|}{ Gross Beta Particle Radioactivity } \\
\hline Gross Beta Activity & 50 & $\mathrm{pCi} / \mathrm{L}$ \\
\hline Tritium & 20,000 & $\mathrm{pCi} / \mathrm{L}$ \\
\hline Stront ium-90 & 8 & $\mathrm{pCi} / \mathrm{L}$ \\
\hline Radium $226 \& 228$ & 5 & $\mathrm{pCi} / \mathrm{L}$ \\
\hline Radium-226 & 3 & $\mathrm{pC} i / L$ \\
\hline \multicolumn{3}{|c|}{ II. Carcinogens } \\
\hline Acrylamide & 0.02 & $\mu g / L$ \\
\hline Acrylonitrile & 0.07 & $\mu g / L$ \\
\hline Aldrin & 0.005 & $\mu g / L$ \\
\hline Aniline & 14 & $\mu g / L$ \\
\hline Aramite & 3 & $\mu g / L$ \\
\hline Arsenic & 0.05 & $\mu g / L$ \\
\hline Azobenzene & 0.7 & $\mu g / L$ \\
\hline Benzene & 1.0 & $\mu g / L$ \\
\hline Benzidine & 0.0004 & $\mu g / 1$ \\
\hline Benzo (a)pyrene & 0.008 & $\mu g / L$ \\
\hline Benzotrichloride & 0.007 & $\mu g / L$ \\
\hline Benzyl chloride & 0.5 & $\mu g / L$ \\
\hline Bis(chloroethyl)ether & 0.07 & $\mu g / L$ \\
\hline Bis(chloromethyl)ether & 0.0004 & $\mu g / L$ \\
\hline Bis(2-ethylhexyl) phthalate & 6.0 & $\mu g / L$ \\
\hline
\end{tabular}


WHC-EP-0470-1

Table 3-2. Groundwater Quality Criteria. (5 sheets)

\begin{tabular}{|c|c|c|}
\hline \multicolumn{3}{|c|}{ II. Carcinogens (Cont'd) } \\
\hline Bromodichloromethane & 0.3 & $\mu g / L$ \\
\hline Bromoform & 5 & $\mu g / L$ \\
\hline Carbazole & 5 & $\mu g / L$ \\
\hline Carbon tetrachioride & 0.3 & $\mu g / L$ \\
\hline Chlordane & 0.06 & $\mu g / L$ \\
\hline Chlorodibromomethane & 0.5 & $\mu g / L$ \\
\hline Chloroform & 7.0 & $\mu g / L$ \\
\hline 4 Chloro-2-methyl aniline & 0.1 & $\mu g / L$ \\
\hline 4 Chloro-2-methyl analine hydrochloride & 0.2 & $\mu g / L$ \\
\hline o-Chloronitrobenzene & 3 & $\mu g / L$ \\
\hline p-Chloronitrobenzene & 5 & $\mu g / L$ \\
\hline Chlorthalonil & 30 & $\mu g / L$ \\
\hline Diallate & 1 & $\mu g / L$ \\
\hline DDT (includes DDE and DDD) & 0.3 & $\mu g / L$ \\
\hline 1,2 Dibromoethane & 0.001 & $\mu g / L$ \\
\hline 1,4 Dichlorobenzene & 4 & $\mu g / L$ \\
\hline 3,3' Dichlorobenzidine & 0.2 & $\mu g / L$ \\
\hline 1,1 Dichloroethane & 1.0 & $\mu g / L$ \\
\hline 1,2 Dichloroethane (ethylene chloride) & 0.5 & $\mu g / L$ \\
\hline 1,2 Dichloropropane & 0.6 & $\mu g / L$ \\
\hline 1,3 Dichloropropene & 0.2 & $\mu g / L$ \\
\hline Dichlorvos & 0.3 & $\mu g / L$ \\
\hline Dieldrin & 0.005 & $\mu g / L$ \\
\hline 3,3' Dimethoxybenzidine & 6 & $\mu g / L$ \\
\hline 3,3 Dimethylbenzidine & 0.007 & $\mu g / L$ \\
\hline 1,2 Dimethylhydrazine & 60 & $\mu g / L$ \\
\hline 2,4 Dinitrotoluene & 0.1 & $\mu g / L$ \\
\hline 2,6 Dinitrotoluene & 0.1 & $\mu g / L$ \\
\hline 1,4 Dioxane & 7.0 & $\mu \mathrm{g} / \mathrm{L}$ \\
\hline
\end{tabular}


Table 3-2. Groundwater Quality Criteria. (5 sheets)

\begin{tabular}{|c|c|c|}
\hline \multicolumn{3}{|c|}{ II. Carcinogens (Cont'd) } \\
\hline 1,2 Diphenylhydrazine & 0.09 & $\mu g / L$ \\
\hline Direct $B 1$ ack 38 & 0.009 & $\mu g / L$ \\
\hline Direct Blue 6 & 0.009 & $\mu g / L$ \\
\hline Direct Brown 95 & 0.009 & $\mu g / L$ \\
\hline Epichlorohydrin & 8 & $\mu g / L$ \\
\hline Ethyl acrylate & 2 & $\mu g / L$ \\
\hline Ethylene dibromide & 0.001 & $\mu g / L$ \\
\hline Ethylene thiourea & 2 & $\mu g / L$ \\
\hline Folpet & 20 & $\mu g / L$ \\
\hline Furazolidone & 0.02 & $\mu g / L$ \\
\hline Furium & 0.002 & $\mu g / L$ \\
\hline Furmecyclox & 3 & $\mu g / L$ \\
\hline Heptachlor & 0.02 & $\mu g / L$ \\
\hline Heptachlor Epoxide & 0.009 & $\mu g / L$ \\
\hline Hexachlorobenzene & 0.05 & $\mu g / L$ \\
\hline Hexachlorocyclohexane (alpha) & 0.001 & $\mu g / L$ \\
\hline Hexachlorocyclohexane (technical) & 0.05 & $\mu g / L$ \\
\hline Hexachlorodibenzo-p-dioxin, mix & 0.00001 & $\mu g / L$ \\
\hline Hydrazine/Hydrazine sulfate & 0.03 & $\mu g / L$ \\
\hline Lindane & 0.06 & $\mu g / L$ \\
\hline 2 Methoxy-5-nitroaniline & 2 & $\mu g / L$ \\
\hline 2 Methylaniline & 0.2 & $\mu g / L$ \\
\hline 2 Methylaniline hydrochloride & 0.5 & $\mu g / L$ \\
\hline $4,4^{\prime}$ Methylene bis(N,N'-dimethyl) aniline & 2 & $\mu g / L$ \\
\hline Methylene chloride (dichloromethane) & 5 & $\mu g / L$ \\
\hline Mirex & 0.05 & $\mu g / L$ \\
\hline Nitrofurazone & 0.06 & $\mu g / L$ \\
\hline $\mathrm{N}$-Nitrosodiethanolamine & 0.03 & $\mu g / L$ \\
\hline $\mathrm{N}$-Nitrosodiethyl amine & 0.0005 & $\mu g / L$ \\
\hline
\end{tabular}


WHC-EP-0470-1

Table 3-2. Groundwater Quality Criteria. (5 sheets)

\begin{tabular}{|c|c|c|}
\hline \multicolumn{3}{|c|}{ II. Carcinogens (Cont'd) } \\
\hline $\mathrm{N}$-Nitrosodimethlamine & 0.002 & $\mu g / L$ \\
\hline $\mathrm{N}$-Nitrosodiphenyl amine & 17 & $\mu g / L$ \\
\hline N-Nitroso-di-n-propylamine & 0.01 & $\mu g / L$ \\
\hline $\mathrm{N}$-Nitrosopyrrolidine & 0.04 & $\mu g / L$ \\
\hline N-Nitroso-di-n-butylamine & 0.02 & $\mu g / L$ \\
\hline $\mathrm{N}-\mathrm{Nitroso}-\mathrm{N}$-methylethyl amine & 0.004 & $\mu g / L$ \\
\hline Polyaromatic Hydrocarbons (PAH) & 0.01 & $\mu g / L$ \\
\hline Polybrominated Biphenyls (PBBs) & 0.01 & $\mu g / L$ \\
\hline Polychlorinated Biphenyls (PCBs) & 0.01 & $\mu g / L$ \\
\hline o-Phenylenediamine & 0.005 & $\mu g / L$ \\
\hline Propylene oxide & 0.01 & $\mu g / L$ \\
\hline $2,3,7,8$-Tetrachlorodibenzo-p-dioxin & 0.0000006 & $\mu g / L$ \\
\hline Tetrachloroethylene (perchloroethylene) & 0.8 & $\mu g / L$ \\
\hline$p, \alpha, \alpha, \alpha$-Tetrachlorotoluene & 0.004 & $\mu g / L$ \\
\hline 2,4 Toluenediamine & 0.002 & $\mu g / L$ \\
\hline o-Toluidine & 0.2 & $\mu g / L$ \\
\hline Toxaphene & 0.08 & $\mu g / L$ \\
\hline Trichloroethylene & 3 & $\mu g / L$ \\
\hline $2,4,6$-Trichlorophenol & 4 & $\mu g / L$ \\
\hline Trimethyl phosphate & 2 & $\mu g / L$ \\
\hline Vinyl chloride & 0.02 & $\mu g / L$ \\
\hline
\end{tabular}

Metals are measured as total metals.

$\mathrm{mg} / \mathrm{L}=$ milligrams/liter .

$\mathrm{mL}=$ milliliter

$p C i / l=$ pico Curie/liter .

$\mu g / L=$ micrograms $/$ liter . 
Discharges to a navigable waterway also will be subject to certain standards based on the industrial process that generated the waste water; certain additional limitations are typically imposed in the National Pollutant Discharge Elimination System permit. In all cases, the specific pollutants to be monitored and the frequency of monitoring and reporting will be based on the applicable regulations and the language of the permit. 


\subsection{IDENTIFICATION AND CHARACTERIZATION OF EFFLUENT STREAMS}

This section addresses the chemical and radiological composition of $\mathrm{UO}_{3}$ Plant effluents. A description of the gaseous effluents is followed by a brief discussion of their routine and upset operating conditions. Liquid effluents are then similarly described.

\subsection{IDENTIFICATION NNO CHARACTERIZATION OF SOURCE TERMS CONTRIBUTING TO EACH AIR EFFLUENT STREAM}

Three air exhaust stacks are active during the $\mathrm{UO}_{3} \mathrm{Plant}$ transition to shutdown. They are the 296-U-2, 296-U-4, and 296-U-13 stacks. (Stack exhaust data are summarized in Table 4-1.)

\subsubsection{Discharge Descriptions}

4.1.1.1 Radioactive Emissions. The source of airborne contaminants during the transition to shutdown is residual fugitive material, vapors, or gases picked up by the air currents in the $\mathrm{UO}_{3}$ buildings and subsequently entrained into the ventilation systems' building exhausts. Annual releases were determined by multiplying the exhaust flow rate for each stack by the outgoing air concentration of each specific radionuclide. The concentration of a specific radionuclide in the air effluents was either measured selectively at the discharge point or was inferred from measurements of gross alpha and gross beta radioactivity. The concentration of uranium nuclides was available only as a composite, i.e., combined ${ }^{234} U$, ${ }^{235} U$, ${ }^{238} \mathrm{U}$, etc. concentrations. It has been assumed that uranium exists solely as ${ }^{234} U$. This is a worst-case assumption and results in a slightly higher calculated EDE. In all stack effluents, the concentration of some radionuclides was below detectable limits. In these cases, the limit of detection for that radionuclide was used as a conservative estimate of its concentration.

During transition to shutdown at the $\mathrm{UO}_{3} \mathrm{Plant}$, releases from the exhaust stack include limited quantities of radionuclides, as depicted in Table 4-2. These emission data represent stack emissions after HEPA filtration. The data supplied in Table 4-2 are averages computed from data reported in Environmental Releases for Calendar Year 1992, WHC-EP-0527-2, WHC 1993a).

4.1.1.2 Other Hazardous Releases. During the transition to shutdown no calcining of $100 \%$ UNH will occur and there are no nonradioactive hazardous air pollutant releases. Consequently, exposure to, and uptake by, the maximally exposed individual (MEI) are zero.

\subsubsection{Routine Operating Conditions}

The ventilation systems will continue to exhaust the same areas of the $\mathrm{UO}_{3} \mathrm{Plant}$ as described in Section 2.2. However, because the $\mathrm{UO}_{3}$ Plant will be placed in a making a transition to shutdown, the source radionuclides that are vented will be reduced and effluent concentrations are expected to be at or 
below the values given in Table 4-2. Radionuclide emissions are expected to be similar to the values given in Table 4-2 during $\mathrm{UO}_{3}$ Plant's transition for shutdown.

\subsubsection{Upset Operating Conditions}

The upset release as prescribed by EPA regulations, National Emission Standards for Hazardous Air Pollutants (NESHAP), (40 CFR 61, Subpart H) (EPA 1991a) is to be the failure of a single engineered barrier. For the $\mathrm{UO}_{3} \mathrm{Pl}$ ant exhausts, this was taken to be failure of the HEPA filters. The increase in effluent radionuclides is described in Section 4.1.4.2 for 296-U-2 and 296-U-13 stacks. Filtration is not provided for the 296-U-4 stack. A fiber mist eliminator was added to the 296-U-4 stack in 1991. The demister will minimize carryover of contaminants from the $\mathrm{C}-2$ recycle concentrator during transition to shutdown.

\subsubsection{Dispersion Modeling}

Only radiological emissions are present in the $\mathrm{UO}_{3} \mathrm{Plant}$ air effluent during the transition to shutdown. The CAP-88 computer code calculates dose commitments that result from the air transport of radionuclides released from the effluent discharge points above the $\mathrm{UO}_{3}$ facility.

CAP-88 is approved by the EPA for demonstrating compliance with the NESHAPs (EPA 1991a) standard for radiological releases. CAP-88 computes the radiation exposure to the maximally exposed individual (MEI) via the ingestion, inhalation, air-immersion (exposure resulting from being inside a plume of radiation), and groundshine (exposure resulting from deposited radioactive particles) pathways. CAP-88 incorporates dose conversion factors from the International Commission on Radiological Protection (ICRP) 26/30 methodology. Resulting doses are a 50-year committed effective dose equivalent. The magnitude of exposure via any of the aforementioned pathways is strongly related to the distance between the source and receptor.

CAP-88 uses a gaussian plume methodology for dispersing air contaminants to downwind locations. Because of the low temperatures of the $\mathrm{UO}_{3}$ stacks, CAP-88 calculates plume rise solely from stack exhaust velocity. During transport, the plume undergoes a reduction in air concentration, not only through dispersion, but also from plume depletion processes.

These processes include radioactive decay, precipitation, scavenging, and dry deposition. Because of the long half-lives of the radionuclides released, and because of the relatively dry climate in eastern Washington, only the dry deposition process has an appreciable effect on the resulting downwind air concentration.

A total of three air effluent stacks contribute nearly all of the airborne radionuclide releases from the $\mathrm{UO}_{3} \mathrm{Plant}$. Each stack possesses its own unique stack characteristics including stack height above the ground, stack diameter, and exhaust velocity or flow rate. Stack characteristics are used to assess the plume rise and determine the final height of release of the 
plume. Air effluents are released at nearly room temperature; as such, plume rises are not thermally driven. Table 4-1 summarized the characteristics of the three $\mathrm{UO}_{3}$ exhaust stacks.

The emission points used for modeling purposes are centered on each of the major Hanford Site operating areas that released radionuclides to the atmosphere. For the $\mathrm{VO}_{3}$ Facility, located in the 200 West Area, the reference point was the meteorology tower located approximately midway between the 200 East and 200 West Areas. This location was chosen to represent emissions from the 200 Areas because it lies between two major groups of facilities that account for the bulk of stack releases. A farm at Ringold, Washington, was determined to be the best location to use in the compliance analysis. Table 4-2 (RL 1993) shows the unit dose conversion factors for the Offsite Hypothetical MEI for the 200 Areas used to calculate the EDE. An 89 meter release height is used for stacks that exceed 40 feet in height (Carter 1993).

4.1.4.1 Radiological Dose Assessment. During normal operations in shutdown mode at the $\mathrm{UO}_{3} \mathrm{Plant}$, only small quantities of radionuclides are released from the exhaust stacks (Table 4-3). The maximally exposed individual used for the Hanford Site dose calculations is located approximately $26 \mathrm{~km}$ (16 mi)

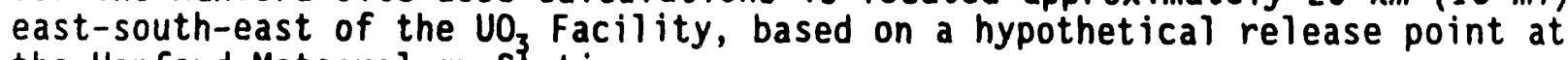
the Hanford Meteorology Station.

A total dose of $4.6 \times 10^{-10}$ rem EDE was assessed for the MEI location described above as a result of releases from all three $\mathrm{UO}_{3} \mathrm{Plant}$ stacks analyzed. This total dose is well below the EPA annual dose criterion (EPA 1991a) of 10 mrem to the MEI via the air pathway. This total dose is not used to establish monitoring requirements, but rather it is used for emission compliance purposes for the total facility releases.

Table 4-4 summarizes the individual stack contributions to the MEI dose

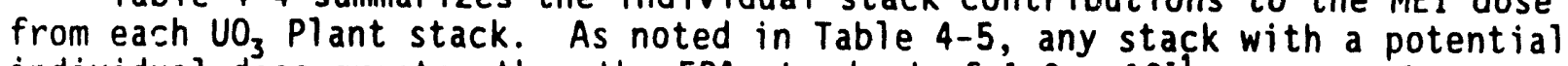
individual dose greater than the EPA standard of $1.0 \times 10^{-1} \mathrm{mrem}$, or 1 percent of $10 \mathrm{mrem} / \mathrm{yr}$, is required to have continuous radiation monitoring. This continuous radiation monitoring is an EPA designation, but is fully met by continuous sampling followed by periodic analysis. The main $\mathrm{UO}_{3} \mathrm{Stack}$ $(296-U-4)$ contributes nearly all of the $4.7 \times 10^{-10}$ rem dose to the MEI. This dose is well below the $1.0 \times 10^{-1}$ mrem annual dose standard for required continuous monitoring.

The MEI dose resulted primarily from the inhalation of U-234 originating from the main exhaust stack at the $\mathrm{UO}_{3}$ Plant $(296-U-4)$. Inhalation of ${ }^{239} \mathrm{Pu}$ al so contributed a significant percentage of the dose. Table 4-5 summarizes the most significant radionuclides and their dose contributions to the MEI. As noted in Table 4-5, any stack containing radionuclides that individualiy contribute $10 \%$ of the dose from a release point which could exceed the EPA annual dose of $1.0 \times 10^{-1}$ mrem EDE, must be selectively monitored for those radionuclides. None of the stacks at the $\mathrm{UO}_{3}$ Plant exceed the EPA annual dose standard; therefore, no specific radionuclide analysis is required.

4.1.4.2 Unmitigated Releases. Applicable EPA regulations require that a dose to the MEI be calculated from an unmitigated release. The unmitigated release is that which occurs if all air pollution control equipment fails or is 
removed. At the $\mathrm{UO}_{3} \mathrm{Plant}$, this means a dose resulting from the unfiltered flow from each of the stack effluents, as described in Table 4-6. The filtering efficiency varies for different stacks. Monitoring of the effluent stream is not performed before the stream passes the HEPA filters. Consequently, the increase in effluent radionuclides caused by filter removal is based on an evaluation of filter efficiencies and particulate removal processes. Stacks 296-U-2 and 296-U-13 exhaust through HEPA filters. A realistic increase in particulate effluent caused by filter removal is $3.0 \times 10^{3}$ for those stacks. The main stack (296-U-4) exhausts without HEPA filtration and will therefore not increase particulate emissions in an unmitigated release scenario.

The dose calculated for the MEI is directly proportional to the amount of radioactive material released. Because all particulate releases are increased by the same amount in a given stack, the resulting unmitigated dose is the MEI dose increased by an unmitigated release factor of $3.0 \times 10^{3}$ for stacks 296-U-13 and 296-U-2. The release for the main stack, 296-U-4, remains unchanged.

Table 4-6 summarizes the contributions to the unmitigated MEI dose from each $\mathrm{UO}_{3}$ Plant stack. As noted in Table 4-6, any stack with an individual annual dose greater than the EPA standard of $1.0 \times 10^{-1}$ mrem is required to have a minimum of continuous sampling and subsequent analysis. None of the stacks have unmitigated dose consequences that are in excess of this standard.

The unmitigated MEI dose resulted primarily from the inhalation of $U$ and Pu originating from 296-U-4. Table 4-8 summarizes the most significant radionuclides and their dose contributions to the MEI from an unmitigated release. As noted in Table 4-8, any radionuclides that contribute more than $10 \%$ of the EDE for the stack release, if above $1.0 \times 10^{-1}$ mrem EDE, must be selectively monitored at the exhaust point. The stack does not have unmitigated releases that exceed the $1.0 \times 10^{-1}$ mrem EDE standard. No radionuclide selective analysis is required.

Because only periodic monitoring to verify continued low radionuclide emissions will be required, the gaseous effluent in the $\mathrm{UO}_{3}$ Plant stacks will be sampled periodically for specific radionuclides using existing equipment and the criteria provided in applicable $\mathrm{UO}_{3}$ Plant operating procedures. At a minimum, air samples from the stacks will be analyzed for total Alpha radioactivity, total Beta radioactivity, Uranium, ${ }^{90} \mathrm{Sr},{ }^{249} \mathrm{Am}, \mathrm{Pl}$ utonium Isotopes, and ${ }^{137} \mathrm{Cs}$. The sampling program for air effiuents should be reported as discussed in Section 10.0 .

\subsection{IDENTIFICATION AND CHARACTERIZATION OF SOURCE TERMS CONTRIBUTING TO EACH WATER EFFLUENT STREAM}

There are two liquid waste streams at the $\mathrm{UO}_{3} \mathrm{Plant}$ : process condensate and plant waste water. 


\subsubsection{Discharge Descriptions}

The $\mathrm{UO}_{3}$ water effluents are described in detail in two stream-specific reports that were written to reflect the $\mathrm{UO}_{3} \mathrm{Plant}$ in its operating and standby or shutdown modes (WHC 1990a). The compositions of the streams are given in Table 4-9. Composition data are the upper limits of the 90 percent confidence interval as given in the stream-specific reports (WHC 1990a). Table 4-9 also indicates the average flow rate, point of discharge, and stream-specific report number for each stream.

\subsubsection{Routine Operating Conditions}

4.2.2.1 Process Condensate. The process condensate discharge consists almost entirely of condensates formed when process off-gas streams pass through either of two vessel vent condensers. The cooling water used by these condensers is the major combonent of the $\mathrm{UO}_{3}$ Plant waste water effluent. All condensates drain into the condensate collection Tank-X37. From the tank, batches of condensate are pumped to a neutralization tank where a buffering agent (phosphoric acid) is added and the condensate is brought to neutral pH using potassium hydroxide.

The process condensate has many contributors (Figure 4-1) and is subject to entrained chemicals in mists, volatile species which co-condense with water, and compounds present in the raw water. Raw water is added, when required, to ensure uninterrupted flow to the acid absorber tower. Raw water is added only during processing. A detailed description of the process condensate is given in the stream-specific report for this effluent (WHC 1990a).

The data compiled in the process condensate stream-specific report represent five samples that were collected during a 7-month period in 1988 . One sample was collected during uranium calcination operations, while the remaining four samples were collected during standby conditions. Evaluation of these data indicated that the process condensate did not contain any dangerous wastes, as defined by WAC 173-303-070 (WAC 1991a). A full discussion of the chemicals detected in the samples, the reported concentrations of these chemicals, analytical detection limits, and the pertinent regulatory limits is contained in the stream-specific report (WHC 1990a). A summary of the data from the report are presented in Table 4-8.

The process condensate flow rate is rather consistent during the transition to shutdown, with only slight variations. The average flow rate reported in the stream-specific report (WHC $1990 \mathrm{a}$ ) is $5.0 \times 10^{+4} \mathrm{~L} / \mathrm{month}$. The extrapolated average monthly flow rate for calcination operating mode is $9.2 \times 10^{+5} \mathrm{~L} /$ month based on a short calcination period.

4.2.2.2 $\mathrm{UO}_{3} / \mathrm{U} \mathrm{Plant} \mathrm{Waste} \mathrm{Water.} \mathrm{The} \mathrm{UO}_{3} \mathrm{Pl}$ ant waste water during the transition to shutdown consists almost entirely of either raw or sanitary water used as cooling water for condensers or compressors. A small quantity of steam condensate from building or tank heaters also contributes to the flow. The raw water that is used, either directly or processed into steam or 
sanitary water, is derived from the Columbia River. The effluents are collected into a common discharge line on the west side of the $\mathrm{UO}_{3}$ Plant (Figure 4-2).

The waste water stream is designed to be an uncontaminated stream. Except for off-normal conditions such as catastrophic equipment failure, none of the contributing sources comes directly into contact with any process fluids. No chemicals other than unregulated quantities of desiccants and water treatment chemicals are added to the waste water in the $\mathrm{UO}_{3} \mathrm{Plant}_{\text {. }}$ A detailed description of the $\mathrm{UO}_{3}$ Plant waste water is given in the stream-specific report for this effluent (WHC 1990a).

The data compiled in the stream-specific report (WHC 1990b) represent four samples that were collected while the $\mathrm{UO}_{3}$ Plant was in standby mode. The evaluation concluded that the $\mathrm{UO}_{3} \mathrm{Pl}$ ant waste water did not contain any dangerous wastes, as defined by WAC-173-303-070 (WAC 1991a). A full discussion of the chemicals detected in the samples, the reported concentrations of these chemicals, analytical detection 1 imits, and the pertinent regulatory limits is contained in the stream-specific report (WHC 1990a). A summary of the statistical data from the report was presented in Table 4-8.

The waste water flow rate is dependent upon process activities; the flow rates reported in the stream-specific report (WHC 1990a) ranged from $1.8 \times 10^{+7}$ to $2.6 \times 10^{+7} \mathrm{~L} /$ month. This range will be maintained while the $\mathrm{UO}_{3} / \mathrm{U}$ Plant is in shutdown. Until the Treated Effluent Disposal Facility (TEDF) and Best Available Technology (BAT) systems are complete, the $\mathrm{VO}_{3}$ waste water will continue to be discharged to the 207-U Retention Basin and 216-U-14 Ditch.

\subsubsection{Upset Operating Conditions}

4.2.3.1 Process Condensate. During transition to standby, process condensate is accumulated in tank TK-X-37. When enough condensate has accumulated, the collected condensate is quarantined and analyzed for radionuclides and nitrate. If sample results are acceptable, sub-batches of the condensate are automatically neutralized and discharged to Crib 216-U-17. Redundant $\mathrm{pH}$ interlocks and fail-safe control features prevent the release of unneutralized condensate. If sample results show that the solution is unacceptable, it is reworked through the recycle concentrator, TK-C-2. This batch release strategy prevents process upsets from releasing hazardous materials to the environment.

4.2.3.2 $\mathrm{UO}_{3} / \mathrm{UPlant}$ Waste Water. The plant waste water stream routinely discharges through either section of the 2-section 207-U Retention Basin and then into the 216-U-14 Ditch. In-line monitoring for $\mathrm{pH}$ upstream of the 207-U Retention Basin allows manual isolation and treatment of off-normal conditions before disposal. Detection of hazardous chemicals or radionuclides is through analysis of periodic samples. 


\subsubsection{Liquid Effluent Criteria}

The $\mathrm{UO}_{3} \mathrm{Pl}_{\text {ant }}$ waste water and $\mathrm{UO}_{3} \mathrm{Pl}$ ant process condensate streams will be discontinued when the transition to standby is completed. Project W-291 which was to connect these streams to the TEDF (SALDS) has been de-scoped. As a contingency, a truck load-out system is being installed to transfer smail amounts of potentially contaminated storm water or flush solutions to the C-018 liquid effluent treatment plant during shutdown.

Based on Ecology guidance, SALDS will consider an effluent that is below the most restrictive criteria acceptable for soil column discharge. A listing of the most restrictive criteria has been prepared for estabilishing acceptance criteria. This list is reproduced in Section 16.2.

The listing does not contain numerical limits for all potential contaminants. However, it does contain limits for regulated constituents that could possibiy be found in the $\mathrm{UO}_{3}$ Plant waste water effluents. To be acceptable for discharge to the SALDS, the radionuclide content of each waste stream will be required to meet the intent of the State's groundwater standards and limit annual public exposure to an EDE not to exceed $4 \mathrm{mrem} / \mathrm{yr}$. The numerical values shown in the listing are $4 \%$ of the Derived Concentration Guides (DCG) (DOE 1990a) which represent an annual EDE of 100 mrem. 
Figure 4-1. Contributors to $\mathrm{UO}_{3} \mathrm{Plant}$ Process Condensate.






\section{WHC-EP-0470-1}

Figure 4-2. $\mathrm{UO}_{3} / \mathrm{U}$ Plant Waste Water Routing.




WHC-EP-0470-1

Table 4-1. $\mathrm{UO}_{3}$ Stack Exhaust Data.

\begin{tabular}{|c|c|c|c|c|c|c|c|c|}
\hline \multirow{2}{*}{$\begin{array}{c}\text { Stack } \\
\text { reference }\end{array}$} & \multicolumn{2}{|c|}{ Height* } & \multicolumn{2}{|c|}{ Diameter } & \multicolumn{2}{|c|}{ Flow } & \multicolumn{2}{|c|}{ Temperature } \\
\hline & $(\mathrm{ft})$ & (m) & $\overline{(f t)}$ & (m) & $\left(\mathrm{ft}^{3} / \mathrm{min}\right)$ & $\left(\mathrm{m}^{3} / \mathrm{s}\right)$ & $\bar{C}$ & $\bar{k}$ \\
\hline $296-U-2$ & 41 & 12.5 & $\begin{array}{c}1.17 \mathrm{ft} \\
0.356 \mathrm{~m}\end{array}$ & $\begin{array}{l}\mathrm{ft}^{* \star} \\
05 \mathrm{~m}\end{array}$ & 1,500 & 0.708 & 50 & 323 \\
\hline $296-U-4$ & 119 & 36.5 & 0.83 & 0.25 & 2,300 & 1.08 & 20 & 293 \\
\hline $296-U-13$ & 55 & 16.8 & 2.08 & 0.64 & 6,000 & 2.83 & 50 & 323 \\
\hline
\end{tabular}

*Stack height is measured from the ground.

**296-U-2 stack has a rectangular effluent outlet. 
Table 4-2. CAP-88 Unit Dose Factors for the Offsite Hypothetical Maximally Exposed Individual Affected by Radionuclide Air Emissions from the 200 Area. (DOE 1993a)

\begin{tabular}{|c|c|}
\hline Release Location & 200 Areas \\
\hline Release Height. & $89 \mathrm{~m}$ \\
\hline MEI $^{\circ}$ Location- & $16 \mathrm{mi}(26 \mathrm{~km})$ ESE \\
\hline Radionuclider & $\begin{array}{l}\text { Effective Dose Equivalent } \\
\text { (mrem/Ci-yr) }\end{array}$ \\
\hline \multicolumn{2}{|l|}{$\sqrt[3]{3}$} \\
\hline \multicolumn{2}{|l|}{${ }^{41} \mathrm{Ar}$} \\
\hline \multicolumn{2}{|l|}{${ }^{60} \mathrm{CO}$} \\
\hline${ }^{90} \mathrm{Sr}$ & $4.60 \mathrm{E}-03$ \\
\hline \multicolumn{2}{|l|}{${ }^{106} \mathrm{Ru}$} \\
\hline \multicolumn{2}{|l|}{${ }^{125} \mathrm{Sb}$} \\
\hline${ }^{129} I$ & $6.74 \mathrm{E}-02$ \\
\hline${ }^{137} \mathrm{Cs}$ & $1.50 \mathrm{E}-03$ \\
\hline${ }^{147} \mathrm{Pm}$ & $1.19 \mathrm{E}-04$ \\
\hline \multicolumn{2}{|l|}{${ }^{154} \mathrm{Eu}$} \\
\hline${ }^{212} \mathrm{~Pb}$ & $3.63 E-04^{b}$ \\
\hline $234 \mathrm{U}$ & $3.35 \mathrm{E}-01$ \\
\hline${ }^{235} \mathrm{U}$ & $3.11 E-01$ \\
\hline${ }^{236} \mathrm{U}$ & $3.17 \mathrm{E}-01$ \\
\hline${ }^{238} \mathrm{U}$ & $2.99 \mathrm{E}-01$ \\
\hline${ }^{238} \mathrm{Pu}$ & $8.43 E-01$ \\
\hline $239,{ }^{240} \mathrm{Pu}$ & $9.11 \mathrm{E}-01$ \\
\hline${ }^{241} \mathrm{Pu}$ & $1.45 \mathrm{E}-02$ \\
\hline${ }^{241} \mathrm{Am}$ & $1.38 E+00$ \\
\hline
\end{tabular}

${ }^{\mathrm{a} M E I}=$ Maximally exposed individual.

Dose for this radionuclide is the result of ingrowth from the parent. 
WHC-EP-0470-1

Table 4-3. $\mathrm{UO}_{3}$ Radionuclide Emissions from Exhaust Stacks for 1992.

\begin{tabular}{|l|c|c|c|c|}
\hline \multirow{2}{*}{ Nuclide } & \multicolumn{4}{|c|}{ Activity from exhaust stack - Ci/yr } \\
\cline { 2 - 5 } & $296-U-2$ & $296-U-4$ & $296-U-13$ & Total \\
\hline${ }^{241} \mathrm{Am}$ & NA & ND & NA & ND \\
\hline $239,240 \mathrm{Pu}$ & $1.2 \mathrm{E}-07$ & $4.0 \mathrm{E}-08$ & ND & $1.65 \mathrm{E}-07$ \\
\hline Total U & NA & $9.4 \mathrm{E}-07$ & NA & $9.4 \mathrm{E}-07$ \\
\hline${ }^{137} \mathrm{Cs}$ & NA & $3.8 \mathrm{E}-07$ & NA & $3.8 \mathrm{E}-07$ \\
\hline${ }^{90} \mathrm{Sr}$ & $1.3 \mathrm{E}-07$ & $5.4 \mathrm{E}-08$ & ND & $1.8 \mathrm{E}-08$ \\
\hline Total & $2.5 \mathrm{E}-07$ & $1.4 \mathrm{E}-06$ & ND & $1.71-06$ \\
\hline
\end{tabular}

$N A=$ Not Analyzed

ND $=$ Not Detected

Table 4-4. Doses to the Maximally Exposed Individual for 1992.

\begin{tabular}{|l|c|c|}
\hline \multicolumn{1}{|c|}{ Stack reference } & $\begin{array}{c}\text { Effective dose } \\
\text { equivalent (rem) }\end{array}$ & $\begin{array}{c}\text { Stack contribution to MEI } \\
\text { dose (\%) }\end{array}$ \\
\hline $296-U-4$ & $3.5 \mathrm{E}-10$ & $76 \%$ \\
\hline $296-U-2$ & $1.1 \mathrm{E}-10$ & $24 \%$ \\
\hline $296-U-13$ & $0.0 \mathrm{E}+00$ & 0.00 \\
\hline Total & $4.6 \mathrm{E}-10$ & 100.0 \\
\hline
\end{tabular}

Table 4-5. Individual Radionuclide Doses to the Maximally Exposed Individual for 1992.

\begin{tabular}{|c|c|c|c|}
\hline $\begin{array}{c}\text { Stack } \\
\text { reference }\end{array}$ & $\begin{array}{c}\text { Most significant } \\
\text { radionuclide(s) }\end{array}$ & $\begin{array}{c}\text { Radionuclide dose } \\
\text { (rem) }\end{array}$ & $\begin{array}{c}\text { Dose threshold for } \\
\text { individual radionuclide } \\
\text { monitoring (rem) }\end{array}$ \\
\hline $296-U-4$ & ${ }^{234}, 240$ & $3.2 \mathrm{E}-10$ & $1.0 \mathrm{E}-04$ \\
& $3.6 \mathrm{E}-11$ & $1.0 \mathrm{E}-04$ \\
\hline
\end{tabular}


Table 4-6. Doses to the Maximally Exposed Individual from an Unmitigated Release.

\begin{tabular}{|l|c|c|c|c|}
\hline $\begin{array}{c}\text { Stack } \\
\text { reference }\end{array}$ & $\begin{array}{c}\text { Effective dose } \\
\text { equivalent } \\
\text { (mrem) }\end{array}$ & $\begin{array}{c}\text { Unmitigated } \\
\text { release } \\
\text { factor }\end{array}$ & $\begin{array}{c}\text { Unmitigated } \\
\text { effective dose } \\
\text { equivalent } \\
\text { (mrem) }\end{array}$ & $\begin{array}{c}\text { Dose standard } \\
\text { fork required } \\
\text { monitoring } \\
\text { (mrem) }\end{array}$ \\
\hline $296-\mathrm{U}-4$ & $3.6 \mathrm{E}-10$ & 1.0 & $3.6 \mathrm{E}-10$ & $1.0 \mathrm{E}-04$ \\
\hline $296-\mathrm{U}-2$ & $1.1 \mathrm{E}-10$ & $3.0 \mathrm{E}+03$ & $3.3 \mathrm{E}-07$ & $1.0 \mathrm{E}-04$ \\
\hline $296-\mathrm{U}-13$ & $0.0 \mathrm{E}+00$ & $3.0 \mathrm{E}+03$ & $0.0 \mathrm{E}+00$ & $1.0 \mathrm{E}-04$ \\
\hline
\end{tabular}

*Dose standard for total radioactivity effluent monitoring from 40 CFR 61, Subpart H (EPA 1991a).

Table 4-7. Individual Radionuclide Doses to the Maximally Exposed Individual from an Unmitigated Release.

\begin{tabular}{|c|c|c|c|c|c|}
\hline $\begin{array}{c}\text { Stack } \\
\text { reference }\end{array}$ & $\begin{array}{c}\text { Most } \\
\text { significant } \\
\text { radionucl ide } \\
\text { (s) }\end{array}$ & $\begin{array}{l}\text { Radionuclide } \\
\text { dose (rem) }\end{array}$ & $\begin{array}{l}\text { Unmitigated } \\
\text { release } \\
\text { factor }\end{array}$ & $\begin{array}{l}\text { Unmitigated } \\
\text { radionuclide } \\
\text { dose (rem) }\end{array}$ & $\begin{array}{c}\text { Dose } \\
\text { threshold } \\
\text { for } \\
\text { individual } \\
\text { radionuclide } \\
\text { monitoring } \\
\text { (rem) }\end{array}$ \\
\hline $296-U-4$ & ${ }_{239,}^{234} \mathrm{Uu}_{\mathrm{Pu}}$ & $\begin{array}{l}3.2 \mathrm{E}-10 \\
3.6 \mathrm{E}-11\end{array}$ & $\begin{array}{l}1.0 \\
1.0\end{array}$ & $\begin{array}{ll}3.2 & E-10 \\
3.6 & E-11\end{array}$ & $\begin{array}{l}1.0 \mathrm{E}-04 \\
1.0 \mathrm{E}-04\end{array}$ \\
\hline
\end{tabular}

*Dose standard for total radioactivity effluent monitoring from 40 CFR 61, Subpart H (EPA 1991a). 
Table 4-8. Summary of $\mathrm{UO}_{3}$ Plant Liquid Effluents.' (4 sheets)

\begin{tabular}{|c|c|c|c|}
\hline Analyte ${ }^{2}$ & U/UPW & $\begin{array}{l}\text { PPC }^{5} \\
\text { Calc. }\end{array}$ & $\begin{array}{c}\mathrm{PPC}^{5} \\
\text { Shutdown }\end{array}$ \\
\hline \multicolumn{4}{|c|}{ Inorganic Compounds - Metals $s^{b}$} \\
\hline \multicolumn{4}{|l|}{ Aluminum } \\
\hline \multicolumn{4}{|l|}{ Antimony } \\
\hline \multicolumn{4}{|l|}{ Arsenic } \\
\hline Arsenic (EP Toxic) & $<500$ & & \\
\hline Barium & 30 & 8 & \\
\hline Barium (EP Toxic) & $<1,000$ & & \\
\hline \multicolumn{4}{|l|}{ Beryllium } \\
\hline Boron & 28.5 & & \\
\hline Cadmium & & 2 & \\
\hline Cadmium (EP Toxic) & $<100$ & & \\
\hline Calcium & $1.8 \mathrm{E}+04$ & & \\
\hline Chromium & & 108 & 34.5 \\
\hline Chromium (EP Toxic) & $<500$ & & \\
\hline Copper & 26.7 & & \\
\hline Iron & 33.3 & & 69.6 \\
\hline \multicolumn{4}{|l|}{ Lead } \\
\hline Lead (EP Toxic) & $<500$ & & \\
\hline Magnesium & $4.5 E+03$ & & \\
\hline Manganese & 7 & 9 & \\
\hline Mercury & & 3.7 & \\
\hline Mercury (EP Toxic) & $<20$ & 3.7 & $1.6 \mathrm{E}-01$ \\
\hline Nickel & & 55 & 24.9 \\
\hline Potassium & 745 & $1.2 E+07$ & $5.5 E+05$ \\
\hline \multicolumn{4}{|l|}{ Selenium } \\
\hline Selenium (EP Toxic) & $<500$ & & \\
\hline Silicon & $2.2 E+03$ & & \\
\hline \multicolumn{4}{|l|}{ Silver } \\
\hline Silver (EP Toxic) & $<500$ & & \\
\hline Sodium & $2.1 E+03$ & $2.2 E+04$ & $9.4 E+02$ \\
\hline
\end{tabular}


Table 4-8. Summary of $\mathrm{UO}_{3}$ Plant Liquid Effluents.' (4 sheets)

\begin{tabular}{|c|c|c|c|}
\hline Analyte $e^{2}$ & U/UPW & $\begin{array}{l}\mathrm{PPC}^{5} \\
\text { Calc. }\end{array}$ & $\begin{array}{c}P^{P P C^{5}} \\
\text { Shutdown }\end{array}$ \\
\hline \multicolumn{4}{|c|}{ Inorganic Compounds - Metals ${ }^{b}$ (Cont'd) } \\
\hline Strontium & 97.8 & & \\
\hline Thallium & 6.3 & & \\
\hline Uranium & 2.4 & 419 & 65.5 \\
\hline Zinc & 5.7 & 11 & 5.7 \\
\hline \multicolumn{4}{|c|}{ Inorganic compounds - Ionic Species } \\
\hline Ammonium & 58.6 & & 96 \\
\hline Chloride & $9.7 E+02$ & & $8.4 E+02$ \\
\hline Cyanide & & & 213 \\
\hline Fluoride & 137 & $2.5 E+04$ & $1.0 E+03$ \\
\hline \multicolumn{4}{|l|}{ Fluoride (IC) } \\
\hline \multicolumn{4}{|l|}{ Fluoride (ISE) } \\
\hline Nitrate & 564 & $1.5 E+07$ & $5.4 E+05$ \\
\hline \multicolumn{4}{|l|}{ Nitrite } \\
\hline Phosphate & & $2.7 E+05$ & $2.6 E+05$ \\
\hline Sulfate & $1.1 E+04$ & & $1.8 E+05$ \\
\hline \multicolumn{4}{|c|}{ Organic compounds } \\
\hline Acetone & & 23 & 273 \\
\hline Benzoic acid & & 14 & \\
\hline 1-Butanol & & 5 & \\
\hline 2-Butanone & & 12 & 27.8 \\
\hline 2-Butoxyethanol & & 58 & \\
\hline \multicolumn{4}{|l|}{ Chloroform } \\
\hline Butyl Nitrate & & 44 & \\
\hline t-4-Chlorocyclohexanol & & 78 & \\
\hline Methyl nitrate & & 66 & \\
\hline 2-Methyl-5-propylnonane & & 5 & \\
\hline Nitroethane & & 43 & \\
\hline n-Nitrosodimethylamine & & 4 & \\
\hline Phenanthene & & & 66 \\
\hline
\end{tabular}


Table 4-8. Summary of $\mathrm{VO}_{3} \mathrm{Plant}$ Liquid Effluents.' (4 sheets)

\begin{tabular}{|c|c|c|c|}
\hline Analyte ${ }^{2}$ & U/UPW & $\begin{array}{l}\text { PPC }^{5} \\
\text { Calc. }\end{array}$ & $\begin{array}{c}\mathrm{PPC}^{5} \\
\text { Shutdown }\end{array}$ \\
\hline \multicolumn{4}{|c|}{ Other parameters } \\
\hline Alkalinity & $5.9 E+04$ & & \\
\hline Conductivity $(\mu \mathrm{S})$ & 136 & & \\
\hline Ignitability $\left({ }^{\circ} \mathrm{F}\right)^{3}$ & 199 & & \\
\hline pH (dimensionless) & 6.6 & 7.13 & 7.51 \\
\hline Reac cyanide $(\mathrm{mg} / \mathrm{kg})$ & $<100$ & & \\
\hline Reac sulfide $(\mathrm{mg} / \mathrm{kg})$ & $<100$ & & \\
\hline TDS & $7.5 E+04$ & & \\
\hline Temperature $\left({ }^{\circ} \mathrm{C}\right)$ & 14.6 & 26.2 & 30.1 \\
\hline TOC & $1.1 E+03$ & $6.4 E+03$ & $1.18 E+03$ \\
\hline Total carbon & $1.6 E+04$ & & \\
\hline TOX (as Cl) & 13.8 & 21.8 & 83.1 \\
\hline \multicolumn{4}{|c|}{ Radionuclides ${ }^{6}$} \\
\hline Total alpha & 3.6 & 447 & 0.9 \\
\hline Total beta & 2.5 & $7.1 E+03$ & 816 \\
\hline \multicolumn{4}{|l|}{ Radium $(226+228)$} \\
\hline \multicolumn{4}{|l|}{ Gross uranium-natural } \\
\hline \multicolumn{4}{|l|}{${ }^{3} \mathrm{H}$} \\
\hline${ }^{60} \mathrm{Co}$ & 1.14 & & \\
\hline \multicolumn{4}{|l|}{${ }^{14} \mathrm{C}$} \\
\hline \multicolumn{4}{|l|}{${ }^{90} \mathrm{Sr}$} \\
\hline \multicolumn{4}{|l|}{${ }^{106} \mathrm{Ru}$} \\
\hline \multicolumn{4}{|c|}{${ }^{113} \mathrm{Sn}$} \\
\hline \multicolumn{4}{|l|}{${ }^{129} 1$} \\
\hline \multicolumn{4}{|l|}{${ }^{137} \mathrm{Cs}$} \\
\hline \multicolumn{4}{|l|}{${ }^{144} \mathrm{Ce} / \mathrm{Pr}$} \\
\hline \multicolumn{4}{|l|}{${ }^{147} \mathrm{Pm}$} \\
\hline${ }^{234} \mathrm{U}$ & 1.16 & & \\
\hline $235 \mathrm{U}$ & $1.3 \mathrm{E}-01$ & & \\
\hline${ }^{238} \mathrm{Pu}$ & & & \\
\hline
\end{tabular}


Table 4-8. Summary of $\mathrm{UO}_{3}$ Plant Liquid Effluents.' (4 sheets)

\begin{tabular}{|c|c|c|c|}
\hline Analyte ${ }^{2}$ & U/UPW 5 & $\begin{array}{l}P^{5} C^{5} \\
\text { Calc. }\end{array}$ & $\begin{array}{c}\text { PPC }^{5} \\
\text { Shutdown }\end{array}$ \\
\hline \multicolumn{4}{|c|}{ Radionuclides ${ }^{4}$} \\
\hline${ }^{238} \mathrm{U}$ & 8.7 & & \\
\hline $239,240 \mathrm{Pu}$ & $6.1 E-03$ & & \\
\hline \multicolumn{4}{|l|}{$24 \mathrm{Am}$} \\
\hline $\begin{array}{l}\text { Stream-Specific } \\
\text { Report WHC-EP-0342 } \\
\text { (WHC 1990b) addendum number }\end{array}$ & Addendum 7 & Addendum 19 & Addendum 19 \\
\hline $\begin{array}{l}\text { Approximate average flow } \\
\text { rate } \\
\text { (L/month) }\end{array}$ & $\begin{array}{l}\text { Flow rates dependent } \\
\text { upon process } \\
\text { activities - } \\
\text { range from } \\
1.8 \text { E }+07 \text { to } 2.6 \text { E-07 }\end{array}$ & $9.2 \mathrm{E}+05 \mathrm{~L} /$ month & $\begin{array}{l}5.0 E+0.4 \\
L / \text { month }\end{array}$ \\
\hline Discharge point & $\begin{array}{l}216-U-4 \text { Ditch } \\
(w \text { side of } \\
\mathrm{UO}_{3} / U \text { Plant) }\end{array}$ & $\begin{array}{l}\text { Storage tanks at } \\
\mathrm{UO}_{3} \text { Plant }\end{array}$ & $\begin{array}{l}\text { Storage } \\
\text { tanks at } \\
\mathrm{UO}_{3} \mathrm{Pl}_{\text {ant }}\end{array}$ \\
\hline
\end{tabular}

NOTES:

'Analyte concentrations represented by the 90 percent confidence interval limit (the upper limit of the one-tailed 90 percent confidence interval for all data sets) as reported in the appropriate stream-specific report. When a 90 percent confidence interval limit was not calculated, the maximum observed result is listed. Exception is PPC Calc where mean values are listed.

'Effluent concentrations expressed as micrograms per liter unless indicated otherwise.

${ }^{3}$ Ignitability temperatures are represented by the lower limit of the onetailed 90 percent confidence interval for all data sets.

4 Effluent concentrations for radionuclides expressed as picocuries per liter.

${ }^{5}$ Abbreviations used:

$\mathrm{U} / \mathrm{UPW}=\mathrm{UO}_{3} / \mathrm{U} \mathrm{Pl}$ ant Waste Water $P P C=$ Plant Process Condensate

Calc. = Calcination operation

shutdown $=$ shutdown mode

Reac $=$ reactive

TDS = total dissolved solids

TOC = total organic carbon

TOX = total organic halides

$\mu S=$ microsiemen

IC = fluoride analysis using ion chromatography technique

ISE = fluoride analysis using ion-specific electron technique 
WHC-EP-0470-1

This page intentionally left blank. 
WHC-EP-0470-1

\subsection{EFFLUENT POINT OF DISCHARGE DESCRIPTION}

This section describes the point of discharge for both the air and liquid effluents.

\subsection{AIR EFFLUENTS}

The dimensions of the three active air exhaust stacks were summarized in Table 4-1. The location of each stack is shown in Figure 2-2; all stacks $(296-U-2,296-U-4$, and $296-U-13)$ are located on the bottom center of that page. Figures 2-5, 2-6, and 2-7 show the respective discharge points for all three stacks.

\subsubsection{6-U-4 Stack}

The 296-U-4 Stack system exhausts cooled air from the process off-gas system. This off-gas is composed of process tank vents, calciner off-gases and vapor from the UNH concentrators. The EB-3 and ED-3 condensers are used to remove most condensables before discharge. Flow through the stack is supplied by a 225-psig steam jet, a 125-psig steam jet, and a 2,200 $\mathrm{ft}^{3} / \mathrm{min}$ air blower. The blower, exhausting about $2,200 \mathrm{ft}^{3} / \mathrm{min}$ of air out of $\mathrm{B}-\mathrm{Ce} 11$, is used in conjunction with the jets to provide adequate air flow out of the stack. Isokinetic record sampling and $\mathrm{NO}_{x}$ sampling and monitoring capabilities are provided for this stack.

The 296-U-4 Stack, extending $80 \mathrm{ft}$ above the 224-U roof, is composed of 10-in., Schedule 20, Type-347, stainless steel pipe resting on the junction of a concrete roof beam with a $10-\mathrm{ft}$ shield wall that separates the canyon from the gallery portion of $224-U$. The stack supported at $40 \mathrm{ft}$ and $64 \mathrm{ft}$ above the roof by four guy wires.

\subsubsection{6-U-2 Stack}

The 296-U-2 Stack is located on the 224-UA roof. The 14-in. $\times 12-i n$. rectangular stack is constructed of 16 gauge sheet metal and extends $13 \mathrm{ft}$ above the building roof. A near-isokinetic record sampler is located approximately $2 \mathrm{ft}$ below the top of the stack. Each exhauster $(x-32-1$ and $x-32-2$ ) has a design capacity of $1,500 \mathrm{ft}^{3} / \mathrm{min}$ at 8 in. water vacuum.

The 296-U-2 Stack exhausts air from the powder handling system. Air for this system originates in the pickup bins. Air is subsequently routed through parallel cyclone separators, primary bag filters, and secondary bag filters (where $\mathrm{UO}_{3}$ powder is separated from the air), prefilters, and HEPA filters before reaching the exhausters (Figure 2-4). This system is designed so that one cyclone separator, one primary bag filter, one secondary bag filter, one prefilter, one HEPA filter, and one exhauster are operated at any given time. 


\section{$5.1 .3296-U-13$ Stack}

The 296-U-13 Stack is a new, single-pass, air exhaust system constructed under Project B-255. This system exhausts filtered air from the $\mathrm{UO}_{3}$ powder load-out hood. The filters consist of 80 percent efficient 24-in. by 24-in. by 11-1/2-in. prefilters, and of 24-in. by 24-in. by 11-1/2-in. HEPA filters (Figure 2-7).

The 296-U-13 Stack, located on the 224-UA roof, is $27 \mathrm{ft}$ tall with a 25-in. outside diameter, and is constructed of 16 gauge sheet metal. The exhauster is rated at $6,000 \mathrm{ft}^{3} / \mathrm{min}$ at $6 \mathrm{in}$. water vacuum. A beta/gamma monitor, and a near-isokinetic record sampling system is provided. This systam also has audiovisual alarms (in 224-U Operations Gallery) that indicate abnormal filter differential pressure (DP), abnormal flow conditions, and high radiation release.

\subsection{WATER EFFLUENTS}

The composition, flow rates and discharge points of the two liquid effluents were summarized in Table 4-10. The location of each discharge point can be seen on the bottom half of Figure 2-1 and are located on the bottom half of the page (216-U-14 Ditch and 203-U Storage Tank Enclosure).

Important: (1) isolate, (2) get sample results, and (3) then discharge.

\subsection{1 $\mathrm{UO}_{3} / \mathrm{U}$ Process Condensate}

Process condensate is discharged on a batch-quarantine basis. Periodically, surge tank $x-37$ is isolated from collection tank $C-9$ and sampled. When the sample has been analyzed for radionuclides, the tank contents are discharged to $216-U-17$ via an elementary neutralization system.

During transition to standby, process condensate accumulates in Tk- $X-37$. Periodicaliy, the collected condensate is quarantined in tank $X-37$ by diverting the condenser drains to sump tank $C-7$. The quarantined batch of condensate in tank $X-37$ is analyzed for radionuclides and nitrate. If sample results are acceptable, a series of sub-batches of the quarantined condensate are automatically neutralized and discharged to the crib. No condensate is admitted to Tk-X-37 until the neutralization process has been completed and the elementary neutralization system has been turned off. The process condensate neutralization system is an automatic batch elementary neutralization process. Level interlocks automatically control the transfer pump from surge tank $X-37$ to neutralization tank $C-5$. A predetermined dose of phosphoric acid is pumped from tank TK-C-8 to TK-C-5 every time condensate is pumped from TK-X-37 to TK-C-5. TK-C-5 is equipped with a recirculation loop and a mechanical agitator. Potassium hydroxide from Tk-X-36 is added to the pumped recirculation loop under $\mathrm{pH}$ feedback contrui. When two independent $\mathrm{pH}$ sensors agree that TK-C-5 has stabilized within the target $\mathrm{pH} 6.5$ to 8.5 range, the pumped recirculation loop is diverted to the $216-U-17 \mathrm{crib}$. 


\subsection{2 $\mathrm{UO}_{3} / \mathrm{U}$ Plant Waste Water}

The $\mathrm{UO}_{3} / \mathrm{U}$ Plant Waste Water discharges into the 207-U Retention Basins and then into the 216-U-14 Ditch via the 24-inch main header. The 207-U Retenition Basins consist of two sections, the north basin and the south basin; each has $550,000 \mathrm{gal}$ of capacity. A weir on the separation wall between the two basins allow one bas in to overflow to the other. Inlet and outlet manual valves are provided for each basin. In the event of contamination, the content of the affected basin can be manually isolated while diverting waste water flow to the alternate basin. 
WHC-EP-0470-1

This page intentionally left blank. 


\subsection{EFFLUENT MONITORING/SNMPLING SYSTEM DESIEN CRITERIA}

Airborne and liquid radionuclide concentration monitoring requirements at $\mathrm{UO}_{3}$ are met by sampling and analysis. Airborne chemical monitoring requirements are met through the use of real-time monitors. The design criteria for a system of equipment states the functional requirements that must be met.

\subsection{NEW FACILITIES}

No new facilities or modifications to the existing equipment are being implemented or are currently planned for the monitoring systems at the $\mathrm{UO}_{3}$ Plant.

\subsection{EXISTING FACILITIES}

The equipment used to create both the air and liquid monitor/sample systems for the $\mathrm{UO}_{3} \mathrm{Pl}$ ant is to meet the following common design criteria: the equipment must be accurate, rugged, and low maintenance.

\subsubsection{Airborne Effluent Sampling and Monitoring System Design Criteria}

Specific criteria that apply to the air effluents are the requirements to accomplish the following:

- Sense pressure drop across the HEPA filters

- Take continuous air samples with isokinetic sampling probes, filter holders, and vacuum pumps

- Detect and alarm upon a loss of ventilation flow in any individual effluent.

Design criteria were developed for generic stack sampler/monitor systems to provide system design and operating capabilities as required in current DOE orders and directives, ANSI guidelines, and Rockwell Hanford Operations Environmental Protection Standards. Design criteria were published in RHO-CD-1092, 200 Area Stack Sampler-Monitor Systems Upgrade: Generic Systems Applications (Cammann 1980). These criteria were further developed in 1984 as part of an upgrade of 200 Area stack systems and were published in SD-WM-CR-016, FY 1985200 Area Stack Sampler/Monitor Systems Upgrade (Cammann 1984). 
The design criteria specify that whenever the stack flow rate varies routinely by more than \pm 20 percent, a stack effluent flow-rate monitor with flow-totalizing capability shall be provided. The following are also specified in the design criteria:

- The stack flow-rate monitoring sjstem shall have a flow-rate sensing element located within the stack in a location that will not interfere with the effluent sample extraction probes. The flow-rate transmitter shall provide an electrical signal that is proportional to the stack flow rate, thus controlling a flow-rate indicator and totalizer.

- Flow-probe sensing lines shall be protected from condensation of moisture.

- Should the stack flow rate not vary routinely by \pm 20 percent, periodic flow-rate measurements shall be conducted to verify this condition.

- The sample extraction probes within the stacks shall follow, in general, design guidel ines as presented in ANSI N13.1, 1969, Guide to Sampling Airborne Radioactive Materia is in Nuclear Facilities (ANSI 1969). Sample probes shall be designed to provide a nearisokinetic representative sample extraction based on the average stack velocity.

- The average stack velocity shall be determined from velocity profile measurements taken at or near the point of sample extraction.

- Sample probes shall be located a minimum of five duct diameters downstream and two duct diameters upstream of major flow disturbance points in the exhaust stack, unless the suitability of an alternate location can be demonstrated through repeatable flow profile measurements.

- Sample extraction probes shall be flange mounted to the stack to facilitate periodic removal, inspection, and cleaning activities.

- Sample transport lines shall extend from the probe connection flange to the instrument cabinet located near the stack. Sample transport lines shall be selected and installed in a manner designed to minimize particle loss attributed to gravity settling, turbulent impaction, and electrostatic effects. Sample transport line runs, bends, and tube transitions shall be minimized to the extent practical. Sample transport line bend radij shall be at least ten times the inside diameter of the transport line. Provisions shall be made to inhibit condensation of moisture within sample transport lines. Sample transport lines shall be supported to minimize windinduced vibration effects. 
WHC-EP-0470-1

- Generic system assemblies shall be selected to provide fixed-filterhead record sampling and airborne radiation monitoring capabilities. The type of airborne radiation monitoring required is site specific and shall be appropriate for the radionuclides normally expected in exhaust stack effluents.

- The record sample airstream shall be routed through a 47-mm filter to obtain a buildup sample for laboratory analysis. The record sampling system shall have sample flow-rate indicating and totalizing capabilities. A flow-rate regulator shall be provided to maintain a constant flow rate through the collection filter assembly to compensate for filter-loading effects. Audible and visible alarm signals indicating low sample flow shall be provided locally and to an area subject to frequent or continuous occupancy. The record sample flow rates shall be size to provide optimum samples for laboratory analyses. The product of the sample flow rate (in $\mathrm{ft}^{3} / \mathrm{min}$ ) and the sample collection time (in hours) shall be at least $370 \mathrm{ft}^{3}-\mathrm{h} / \mathrm{min}$. Sample flow rates, however, shall not exceed $4 \mathrm{ft}^{3} / \mathrm{min}$ to maintain filter and sample integrity.

- The continuous air monitor CAM system shall have flow rate indicating and regulating capabilities. A flow-rate regulator shall be provided to maintain a constant flow rate through the collection filter assembly to compensate for filter loading effects. The CAM system shall have local readout count-rate meters with strip chart recording capability to a remote area where alarms are to be located. Audible and visible alarms including, but not limited to, high airborne radiation, instrument malfunction, and low sample flow indications, shall be provided locally and in an area subject to frequent or continuous occupancy.

- Monitoring systems shall have the capability to alarm at the timeintegrated equivalent concentration equal to $4 \mathrm{hr}$ release at 5,000 times the DCG-Public as noted in Appendix A of WHC-CM-7-5, Environmental Compliance Manual (WHC 1993b). Monitoring systems shall alarm at release concentrations as low as possible without resulting in an excessive number of alarms caused by normal fluctuations in background or normal fluctuations in releases.

- The stack sampler/monitor system shall operate continuousiy using the same emergency power backup capabilities as the stack blower $f a n(s)$. An elapsed time meter shall be ganged with stack blower-fan operation to provide a measure of exhaust stack operation times. The record sample vacuum pump shall be ganged to exhaust fan operation via a switched receptacle in the system cabinet. The CAM vacuum pump will operate continuously via the unswitched receptacle in the cabinet.

- Particular attention shall be given to the maintainability, testability, and, therefore, reliability of CAM systems. Failure annunciation shall be provided, and the CAM system shall be checked periodically to verify total system response. 
- Independent vacuum pumps shall be provided for each loop of the system. Redundant vacuum systems need not be furnished, but failure annunciation (low flow rates) shall be provided and checked periodically to demonstrate operability.

- All gaseous effluent sampling and monitoring system equipment shall be protected from, or resistant to, environmental conditions that may cause damage to the equipment or operation thereof. Routine maintenance shall be performed. Performance evaluations of CAM instrumentation against a known standard shall be done periodicaliy.

\subsubsection{Liquid Effluent Sampling and Monitoring System Design Criteria}

Liquid radionuclide sampling is required for all released 1 iquid effluents which have the potential to exceed a sum of the fractions of the derived concentration guide $(D C G)$ of $0.04 \mu \mathrm{Ci} / \mathrm{ml}$. Sampling is al so required for liquid effluents discharged to surface waters with settleable solids exceeding $5 \mathrm{pCi} / \mathrm{g}$ alpha or $50 \mathrm{pCi} / \mathrm{g}$ beta/gamma emitting radionuclides. The samples are required to be representative: either grab samples of well-mixed batch releases or proportional samples of continuous releases.

- Condensate

- Monitoring--Quarantined in surge tank and analyzed for radionuclides before transfer to crib via neutralization system

- Sampling--flow proportional sample from discharge line downstream of neutralization system.

Additional specific criteria that apply to the process condensate water effluent do not exist. Since the condensate is quarantined and analyzed for radionuclides and nitrate prior to discharge, no monitoring system is required. Only tank access for sampling is required. Samples of the tank contents provide detailed information on the effluent composition.

Additional specific criteria that apply to the $\mathrm{UO}_{3}$ waste water effluent are thie requirements to monitor $\mathrm{pH}$ continuousiy with an alarm function for out-of-specification $\mathrm{pH}$ and a flow proportional sampler.

6.2.2.1 Liquid Effluent Monitoring/Sampling General Design Criteria. The general design criteria for 1 iquid effluent sampling and monitoring systems are presented in WHC-CM-4-9, Radiological Design, Section 10.0, REV 0, "Sampling and Monitoring," (WHC 1990b). For sampling systems, the following criteria apply:

- Sampling systems shall be provided for all liquid effluents that have a potential for exceeding concentrations equivalent to the Drinking Water Standards contained in 40 CFR 141 (EPA 1991d). 
- Sampling systems shall be designed to take a representative sample of the effiuent stream. The sample location shall be as close to the environmental discharge point as practical and downstream of the effluent control systems. The sampler should sample only what is discharged to the environment. Samples of a stream diverted from environmental discharge should not be combined with the samples of the discharged effluent.

- Automatic samplers should operate on a flow-proportional basis as controlled by a flow measurement system. The flow-metering device should be equipped with a flow totalizer for recording total effluent volume released from a given source.

- Sampling probes should be suspended in the water so as not to pick up particulate matter from the bottom or top of the stream, pond, or basin.

- The sampler should have a sufficiently high transport velocity to ensure accurate collection and transport of suspended solids to the sample collector. Lengths of sample tubing should be minimized.

- The sampling system should ensure that no unsampled releases occur as a result of power failure (the sampler shall have backup power).

- The sampler should be equipped to minimize cross contamination by sample line flushing or other methods.

- For a batch discharge system, mechanical mixing or other design should ensure reasonable homogeneity of a batch before sampling. The system should have the means for accurate determinations of batch volumes to permit volume-weighed compositing of grab (taken at random) as opposed to continuous, samples.

For monitoring and diversion system, the following criteria apply:

- Monitoring systems shall be provided for all discharged liquid effluents that have the potential of exceeding four times the applicable administrative control limits in WHC-CM-7-5, Westinghouse Hanford Company Environmental Compliance Manual (WHC 1993b).

- Monitoring shall be provided for each radionuclide with the potential for exceeding the values above specified values, unless an increase in one radionuclide concentration is accompanied by proportional increases in another type.

- Monitoring systems should be placed upstream from diversion systems and downstream fror effluent treatment systems.

- Monitors should have distinguishable, audible, and visible highradiation alarms capable of alarming in an area subject to frequent or continuous occupancy. 
- Monitors should have distinguishable, audible, and visible detectorfailure alarms capable of alarming in an area subject to frequent or continuous occupancy. The monitoring system electronics should include a low-count alarm. This module monitors the count rate provided by the electronics and alarms if the count rate drops below a selected level. This acts as a failure alarm for the system components.

- Monitors should have distinguishable, audible, and visible loss-ofsample alarms capable of alarming in an area subject to frequent or cont inuous occupancy.

- Monitors should have distinguishable capability to transmit a realtime measurement to a remote location.

- Accessibility and maintainability should be considered with respect to the system and configuration to accommodate periodic in-place calibration and maintenance.

- A diversion and retention system shall be coupled with the monitoring system if the potential exists for exceeding the limits contained in WHC-CM-7-5, Westinghouse Hanford Company Environmental Compliance Manual (WHC 1993b).

- Retention capacity shall be sufficient to retain the volume of liquid that exceeds the applicable limits based on a safety analysis postulated upset. The retention basin should be covered.

- It should be possible to flush or decontaminate the monitor if a buildup of contamination raises the background radiation levels.

Delivery of a representative portion of the effluent stream to the sampler or monitor depends on the design of the transport line. The following are guidelines for the design of sampler or monitor system transport lines.

- The sampler and monitor should be located as far upstream as practical.

- Traps should be avoided and uphill runs kept as short as practical upstream of the sampler or monitor.

- Grab sample valves, throttling valves, and flow alarms should be downstream of the sampler and monitor.

- To reduce the number of fittings needed, tubing should be used instead of piping. Sample tubing should be as short as practical, have as few valves and bends as possible, and contain no traps.

- Transport velocity in systems with horizontal or uphill runs should be $61 \mathrm{~cm} / \mathrm{s}(2 \mathrm{ft} / \mathrm{s})$ or greater to ensure transport of suspended solids. 
- If a heat exchanger is used, it should be sized to maintain the desired transport velocity and, if practical, the sample should flow downhill.

- The sampler should be upstream of the monitor if both units are on the same transport line.

- The sampler should be separate or separable from the monitor. The two capabilities may be on the same system if either can be isolated by maintenance bypass loops.

6.2.2.2 Liquid Effluent Management Criteria. A liquid effluent management system shall be provided for all radioactive liquid waste discharges to prevent exceeding annual average limits. The system shall ensure summation of monthly release totals for comparison to annual limits using results from required effluent samples. 
WHC-EP-0470-1

This page intentionally left blank. 


\subsection{CHARACTERIZATION OF CURRENT EFFLUENT MONITORING SYSTEM}

Sampling and monitoring systems must be capable of verifying compliance with the discharge criteria for the specific effluent stream. Air monitoring/sampling requirements are defined in 40 CFR 61, NESHAP (EPA 1991a). Currently, liquid effluent sampling and monitoring are used to verify compliance with discharge criteria for effluents discharged to the 207-U Retention Basin and the 216-U-14 Ditch for waste water. After 1996, liquid effluents must meet the more restrictive SALDS criteria (Crane 1991). Sampling and monitoring of the air and liquid effluents will be conducted in accordance with the current standard operating procedures, WHC-CM-7-5 (WHC 1993b).

\subsection{AIR EFFLUENT MONITORING SYSTEM DESCRIPTION AND SPECIFICATIONS}

The descriptions of the air effluent monitoring/sampling program and associated equipment used at $\mathrm{UO}_{3}$ Plant are compiled from information included in engineering drawings (WHC 1982, 1991a) and existing effluent monitoring plans (WHC 1989a).

The FEMP determination analysis (WHC 1991a), which was based on the requirements of 40 CFR 61 (EPA 1989a), concludes that cont inuous monitoring (as defined by EPA but fully met by continuous sampling and periodic analysis) is not required for the three $\mathrm{UO}_{3}$ stacks. Periodic effluent monitoring and sampling should be conducted, however, to verify the low concentrations of radionuclides constituents in the air effluent streams.

No stack at $\mathrm{UO}_{3} \mathrm{Plant}$ requires monitoring for nonradiological hazardous or EPA criteria pollutants during shutdown mode.

\subsubsection{6-U-4 Stack Instrumentation and Controls Specifications}

The major parameters that are controlled in the 296-U-4 off-gas system are the temperature entering and exiting the acid absorbers and the exhaust temperature of the EB-3 and ED-3 condensers.

7.1.1.1 Shutdown. During transition to shutdown conditions, the $\mathrm{UO}_{3}$ Plant acid absorbers, condenser, and $\mathrm{NO}_{x}$ monitor will not be operating. The condensers are only operated when rainwater is processed and the vessel vent system is running. No $\mathrm{NO}_{x}$ is being generated and, therefore, the control system is shut down. Blower and sampler operation will continue.

7.1.1.2 Sampler. A near-isokinetic sampler continuously samples the stack. These samples are collected on a weekly basis when the plant is transitioning to shutdown. The samples were collected on a daily basis when the plant was operating. A preliminary count of its activity is performed to determine if 
the sample has the potential to exceed the release limits of the stack. If the sample does exhibit the potential, the sample analysis is expedited providing sample results within 24 hours. The stack flow is measured each time it is adjusted, and the sample flow is adjusted correspondingly to ensure near-isokinetic sampling.

\subsubsection{6-U-2 Stack Instrumentation and Controls Specifications}

To prevent the release of any significant quantities of $\mathrm{UO}_{3}$ particles to the atmosphere, the differential pressure (DP) across the bag filters is controlled while the vacuum of the bag filters and DP of the HEPA filters are monitored.

The DP across the bag filters is controlled between the values listed in Table 7-1. The alarm set points are also listed in Table 7-1. The low DP alarm indicates the possible failure of a bag. If a bag does fail, the amount of $\mathrm{UO}_{3}$ particles released to the atmosphere before the plant can be shut down will be minimal because of the presence of the prefilters and HEPA filters downstream of the last bag filter. The high-DP alarm indicates that the bag filter has become over-loaded and requires replacement. The high-DP alarm set point for the piimary bag filter is currently set above the operating specifications document efficiency limit. Past operation has shown that DPs greater than 10 in. of water have no effect on the filter integrity.

The DP across the HEPA filters is monitored continuously. Each filter assembly is equipped with both low and high-DP alarms (Table 7-1) that inform plant operations that either the HEPA filter has failed or has become loaded and requires replacement.

A near-isokinetic record sampler continuously samples the stack. These samples are collected on a weekly basis. A preliminary count of its activity is performed to determine if the sample has the potential to exceed the release limits of the stack. If the sample does exhibit this potential, the sample analysis is expedited providing sample results within 24 hours. The stack flow is measured each time it is adjusted, and the sample flow is correspondingly adjusted ensure near-isokinetic sampling.

Based on historical standby release data and the presence of two redundant filter systems, each containing four filters in series (two bag filters, a prefilter, and a HEPA filter), the potential of exceeding the NESHAP (EPA 1991a) control value does not exist. Therefore, a radionuclide monitor is not required for the $U-2$ stack.

\subsubsection{6-U-13 Instrumentation and Controls Specifications}

The exhaust system for the powder load-out hood is equipped with several types of monitors/alarms to warn personnel that a potential exposure or environmental hazard may exist. The types of instrumentation and monitoring equipment associated with the $296-U-13$ stack and their function are listed below. 
Parameter

Stack Flow

No-Flow Alarm

Prefilter Differential Pressure

HEPA Filter Differential Pressure

Radioactive Releases
Funstion

The stack is controlled at a flow rate of approximately $6,000 \mathrm{ft}^{3} / \mathrm{min}$. The flow controller has both a high and low-flow alarm. The low-flow alarm is set at 4,000 $\mathrm{ft}_{3}^{3} / \mathrm{min}$; the high-flow alarm is set at $7,500 \mathrm{ft}^{3} / \mathrm{min}$.

This alarm is used to inform personnel that the $X-44$ exhaust fan is not in operation and requires activation before the hood can be used. It also serves as a warning device for operators if the fan fails.

The DP across the prefilter is monitored to inform personnel when the filters require replacement and/or cleaning. The DP instrument is equipped with a high-level alarm set at 4 in. water to warn personnel when this condition exists.

The DP across the HEPA filters is monitored to inform personnel when the filters have become fully loaded and require replacement. The instrument is equipped with a high-level alarm set at a DP of $4 \mathrm{in}$.

1. The U-13 stack is equipped with a beta CAM. The monitor is used to indicate the concentration of radioactive constituents being released to the environment on a real-time basis. The unit is equipped with a high-level alarm that indicates possible releases and a low-level alarm that indicates possible instrument failure. Activation of either the high- or low-level alarm automatically shuts down the 296-U-13 stack.

2. A near-isokinetic record sampler samples the stack continuously. These samples are collected on a weekly basis. A preliminary count of its activity is performed to determine if the sample has the potential to exceed the release limits of the stack. If the sample does exhibit this potential, the sample analysis is rushed to provide sample results within 24 hours. The stack flow is measured each time it is adjusted, and the sample flow is adjusted correspondingly to ensure near-isokinetic sampling.

\subsubsection{Air Effluent Monitoring Program}

Existing equipment will be used to sample continuously and analyze periodically the gaseous effluent from the $\mathrm{UO}_{3}$ Plant stacks for filter differential pressures, total alpha and beta radiation, and specific radionuclides. The air effluent monitoring program will comply with the criteria provided in the Westinghouse Environmental Compliance Manual, WHC-CM-7-5 (WHC 1993b). 


\subsection{LIQUID EFFLUENTS}

The descriptions of the liquid effluent monitoring/sampling program and assoctated equipment used at the $\mathrm{UO}_{3} \mathrm{Plant}$ are compiled from information included in stream-specific reports (WHC 1990a), engineering drawing H-2-97874, (WHC 1991a), and the existing effluent monitoring plans (WHC 1989a).

\subsubsection{Monitoring/Sampling Requirements}

The concentrations of constituents in each $\mathrm{UO}_{3} \mathrm{Plant}$ liquid waste stream must be below regulatory limits before the effluent can be discharged. The discharge criteria to be met in 1996, based on SALOS acceptance, are compared with the reported effluent quality from the two UO $\mathrm{Pl}$ ant waste streams in Table 7-2. The effluent concentrations presented in the table represent the 90 percent confidence interval 1 imit as reported in the stream-specific reports (WHC 1990a).

7.2.1.1 Routine Conditions. After review of the discharge criteria and available stream-specific data, the following are observed:

- Some effluent concentrations exceed the SALDS acceptance criteria (Crane 1991)

- The selection of analytes for characterization is not consistent with the discharge criteria parameters

- The waste stream characterizations mist be refined before discharge to the SALDS commences.

These deficiencies in the database are largely a function of project scope. The stream-specific reports were prepared to evaluate whether the waste streams were designated dangerous wastes pursuant to the Washington State Dangerous Waste Regulations, WAC 173-303 (WAC 1991a). Process knowledge and historic sampling data were used to select the analytical tests.

7.2.1.2 Monitoring/Diversion Interface. The $\mathrm{UO}_{3} \mathrm{Plant}$ waste water currently discharges into the 207-U Retention Bas in and then into the 216-U-14 Ditch. The process condensate is routed to the neutralization system and discharged to the 216-U-17 Crib after in has been stabilized. No monitoring or diversion interfaces are required.

7.2.1.3 Monitoring/Sampling Criteria and Management System. The effluent concentrations in the process condensate and waste water streams during routine operations of the $\mathrm{UO}_{3} \mathrm{Plant}$ were below the most restrictive applicable federal and state standards for water quality. The effluent concentrations are also expected to meet the intent of the Washington State groundwater protection standards (WAC 1987) while the plant is in shutdown mode. Monitoring and sampling activities will be performed to show compliance with applicable WAC/EPA regulations and appropriate discharge criteria. Monthiy release totals will be summed for comparison to annual limits. Criteria are provided in the "Westinghouse Environmental Compliance Manual, "WHC-CM-7-5 (WHC 1991a). 
Presently, no monitoring instrumentation exists to detect radionuclides in liquid effiuent at the concentrations adopted as SALDS acceptance criteria (Crane 1991). Furthermore, instrumentation that can attain these sensitivities is not commercially available nor is it likely that this type of instrumentation will be developed in the near future. As a result, instrument monitoring will be useful only for detecting and quantifying upset releases. Data for establishing environmental baseline conditions and determining compliance status will be collected by sampling and gathered from analyses.

Uniformity and consistency must be incorporated in the sampling and analysis plan to ensure that the database contains the information necessary for making an informed judgment as to the acceptability of effluent for disposal at the SALDS. The sampling criteria are summarized below.

\subsubsection{Process Condensate Effluent Monitoring/Sampling System}

7.2.2.1 Process Condensate Monitoring/Sampling Description. The Process Condensate stream is currently discharged to the 216-U-17 Crib. Before discharge the stream is held and neutralized in batches. Discharge to the crib occurs after the batch has been stabilized. The discharge stream is continuously monitored for $\mathrm{pH}$ and is flow-proportionally sampled, The samples are analyzed for total alpha, total beta, uranium (gross), $\mathrm{NO}_{3},{ }^{239} \mathrm{Pu}$, and $\mathrm{pH}$.

\subsubsection{Process Condensate Monitoring/Sampling Specifications. Process} condensate is diverted from the neutralization system when the $\mathrm{pH}$ is between 6.5 and 8.5. The discharge is continuous and alarms are sounded when the pH is less than 6.5 or greater than 9. A detailed investigation is given in the stream-specific report for the effluents (WHC 1990a).

\subsubsection{Effluent Monitoring/Sampling System}

\subsubsection{Monitoring/Sampling Description. This stream is currently} discharged into the 207-U Retention Basin and then into the 216-U-14 Ditch. Before discharge to the ditch, the stream is monitored continuously for $\mathrm{pH}$ and is flow-proportionally sampled. No capability exists for monitoring radioactive constituents. Three liquid effluent samples are taken each week. One sample is analyzed for uranium, total alpha radioactivity, total beta radioactivity, and $\mathrm{pH}$. The other two samples are composited for monthly analyses. The monthly analys is examines the sample for: total alpha, total beta, ${ }^{230} \mathrm{Pu},{ }^{241} \mathrm{Am}$, uranium (gross), tritium, ${ }^{99} \mathrm{Tc}$, and $\mathrm{pH}$.

\subsubsection{Monitoring/Sampling Specifications. The $\mathrm{pH}$ of the stream is} monitored continuously and alarms are sounded when the pH is less than 6 or greater than 10. When an out-of-compliance alarm sounds, a manual valve is closed to prevent discharge from 207-U into the 216-U-14 ditch. A detailed investigation of the waste water stream is given in the stream-specific report for the effluent (WHC 1990a) and was summarized in Table 4-9. This report concluded that the stream did not contain any dangerous wastes, as defined by the Washington State Dangerous Waste Regulations, WAC 173-303-070 (WAC 1989a). 
The $\mathrm{UO}_{3}$ FEMP determination document concluded that constituent concentrations in the waste water stream meet existing drinking water and groundwater quality standards (WHC 1990C).

\subsubsection{Monitoring/Sampling Deficiencies. A review of the discharge} criteria for a SALDS (Crane 1991) and available stream-specific data (WHC 1990a) reveals that some effluent concentrations exceed SALDS acceptance criteria. However, the stream-specific reports (WHC 1990a) contain 1989-1990 data and do not reflect the various source reduction, conservation, and other source volume and concentration minimization measures that have recently been implemented. Therefore, the waste stream characterizations must be refined before discharge to the SALDS commences. In addition, the current 222-S Analytical Laboratory detection limits for ${ }^{249} \mathrm{Am}$ and $239,240 \mathrm{Pu}$ are $1.2 \times 10^{-8} \mathrm{mCi} / \mathrm{ml}$ and $5.0 \times 10^{-9} \mu \mathrm{Ci} / \mathrm{ml}$ respectively, (WHC 1990a); thus, the testing of samples to 4 percent of the DCG $\left(1.2 \times 10^{-9} \mu \mathrm{Ci} / \mathrm{ml}\right)$ is not achievable for certain radionuclides.

Table 7-1. Bag Filter Differential Pressure Control Settings and Alarm Points.

\begin{tabular}{|l|c|c|c|c|}
\hline \multirow{2}{*}{ Control settings } & \multicolumn{2}{|c|}{$\begin{array}{c}\text { Alarm points } \\
\left.\text { (in. } \mathrm{H}_{2} \mathrm{O}\right)\end{array}$} & \multicolumn{2}{c|}{$\begin{array}{c}\text { Control points } \\
\left.\text { (in. } \mathrm{H}_{2} \mathrm{O}\right)\end{array}$} \\
\cline { 2 - 5 } & Low & High & Low & High \\
\hline Primary bag filter & 2 & 10 & 2.3 & 7.5 \\
\hline Secondary bag filter & 1 & 7 & 1.2 & 6 \\
\hline HEPA filter & N/A & N/A & 0.5 & 2.5 \\
\hline
\end{tabular}


Table 7-2. Comparison of $\mathrm{UO}_{3} / \mathrm{U}$ Plant Effluent Qualities and State Approved Land Disposal Structure Acceptance Criteria.: (4 sheets)

\begin{tabular}{|c|c|c|c|c|}
\hline Analyte & $\begin{array}{l}\text { Acceptence } \\
\text { criterion }\end{array}$ & U/UPU & $\begin{array}{c}P P C^{f} \\
\text { (Calc mode) }\end{array}$ & $\begin{array}{c}\text { PPC }^{7} \\
\text { (standby } \\
\text { mode) }\end{array}$ \\
\hline \multicolumn{5}{|c|}{ Inorganic compounds - metals ${ }^{c}$} \\
\hline Aleminum & 50 & & & \\
\hline Ant inomy & 5 & & & \\
\hline Arsenic & 50 & & . & \\
\hline Arsenic (EP toxic) & MC & $<500$ & & \\
\hline Barium & 1,000 & 30 & 8 & \\
\hline Bariun (EP toxic) & MC & $<1,000$ & & \\
\hline Beryllium & 1 & & & \\
\hline Boron & MC & 28.5 & & \\
\hline Cadnium & 5 & & 2 & \\
\hline Cactmium (EP toxic) & MC & $<100$ & & \\
\hline Calciun & MC & $1.8 \mathrm{E}+04$ & & \\
\hline Chromium & 50 & & 108 & 34.5 \\
\hline Chromium (EP toxic) & MC & & & \\
\hline Copper & 1,000 & 26.7 & & \\
\hline Iron & 300 & 33.3 & & 69.6 \\
\hline Lead & 5 & & & \\
\hline Lead (EP toxic) & NC & & & \\
\hline Magnesium & NC & $\sqrt{3}$ & & \\
\hline Manganese & 50 & 7 & 9 & \\
\hline Mercury & 2 & & 3.7 & \\
\hline Mercury (EP toxic) & NC & $<20$ & & $1.6 E-01$ \\
\hline Nickel & 100 & & 55 & 24.9 \\
\hline Potassium & NC & 745 & $1.2 E+07$ & $5.5 E+05$ \\
\hline Selenium & 10 & & & \\
\hline Selenium (EP toxic) & NC & $<500$ & & \\
\hline Silicon & NC & $2.2 E+03$ & & \\
\hline silver & 50 & & & \\
\hline silver (EP toxic) & MC & $<500$ & & \\
\hline Sodium & NC & $2.1 \Xi+03$ & $2.2 E+04$ & $9.4 E+02$ \\
\hline Strontium & NC & 97.8 & & \\
\hline Thallium & 1 & 6.3 & & \\
\hline Uranium & MC & 2.4 & 419 & 65.5 \\
\hline Zine & 5,000 & 5.7 & 11 & 5.7 \\
\hline
\end{tabular}


Table 7-2. Comparison of $\mathrm{UO}_{3} / \mathrm{U}$ Plant Effluent Qualities and State Approved Land Disposal Structure Acceptance Criteria.", b (4 sheets)

\begin{tabular}{|c|c|c|c|c|}
\hline Analyte & $\begin{array}{l}\text { Aceeptance } \\
\text { criterion }\end{array}$ & U/NPU' & $\begin{array}{c}\operatorname{PPC}^{f} \\
\text { (Calc node) }\end{array}$ & $\begin{array}{c}\text { PPC' } \\
\text { (standey } \\
\text { aode) }\end{array}$ \\
\hline \multicolumn{5}{|c|}{ Inorganic Compounds - Ionic Speciese } \\
\hline Amonium & NC & 58.6 & & 96 \\
\hline Chloride & $2.5 E+05$ & $9.7 E+02$ & & $8.4 E+02$ \\
\hline Cyenide & 200 & & & 213 \\
\hline Fluoride & 2,000 & 137 & $2.5 E+04$ & $1.0 E+03$ \\
\hline \multicolumn{5}{|l|}{ Flworide (IC) } \\
\hline \multicolumn{5}{|l|}{ Fluoride (ISE) } \\
\hline Nitrate & 10,000 & 564 & $1.5 E+07$ & $5.4 E+05$ \\
\hline Nitrite & 1,000 & & & \\
\hline Phosphate & NC & & & $2.6 E+05$ \\
\hline Sulfate & $2.5 E+05$ & $1.1 E+04$ & $2.7 E+05$ & $1.8 E+05$ \\
\hline \multicolumn{5}{|c|}{ Organic Compounds ${ }^{c}$} \\
\hline Acetone & NC & & 23 & 273 \\
\hline Benzoic acid & NC & & 14 & \\
\hline 1-Butanol & NC & & 5 & \\
\hline 2-Butanone & NC & & 12 & 27.8 \\
\hline 2-Butyoxyethanol & NC & & 58 & \\
\hline Chloroform & 6 & & & \\
\hline Butyl nitrate & NC & & 44 & \\
\hline Dichloromethane & 5 & & & \\
\hline Trans-4- CCH & NC & & 78 & \\
\hline Methyl nitrate & NC & & 66 & \\
\hline Nitroethane & NC & & 43 & \\
\hline n-NDMA & $2 E \cdot 03$ & & 4 & \\
\hline Phenanthrene & NC & & & 66 \\
\hline \multicolumn{5}{|c|}{ Other Parametersc } \\
\hline Alkal inity & NC & $5.9 E+04$ & & \\
\hline Conductivity ( $\mu S)$ & NC & 136 & & \\
\hline Ignitability $\left({ }^{\circ} \mathrm{F}\right)^{\mathrm{d}}$ & NC & 199 & & \\
\hline pH (dimensionless) & $6.5 \cdot 8.5$ & 6.6 & 7.13 & 7.51 \\
\hline Reac cyanide (mg/kg) & NC & $<100$ & & \\
\hline Reac sulfide (mg/kg) & NC & $<100$ & & \\
\hline Tos & $5.0 E+05$ & $7.5 E+04$ & & \\
\hline Temperature & NC & 14.6 & 26.2 & 30.1 \\
\hline
\end{tabular}


Table 7-2. Comparison of $\mathrm{UO}_{3} / \mathrm{U}$ Plant Effluent Qualities and State Approved Land Disposal Structure Acceptance Criteria.'b (4 sheets)

\begin{tabular}{|c|c|c|c|c|}
\hline Analyte & $\begin{array}{l}\text { Acceptance } \\
\text { criterion }\end{array}$ & U/UPU & $\begin{array}{c}\text { PPC }^{f} \\
\text { (Calc mode) }\end{array}$ & $\begin{array}{c}\text { PPC }^{\top} \\
\text { (Standby } \\
\text { mode) }\end{array}$ \\
\hline \multicolumn{5}{|c|}{ Other Parmeters ${ }^{c}$ (Cont 'd) } \\
\hline TOC & MC & $1.1 \mathrm{E}+03$ & $6.4 E+03$ & $1.18 E+03$ \\
\hline Total Carbon & MC & $1.6 \mathrm{E}+04$ & & \\
\hline TOX (as Cl) & MC & 13.8 & 21.8 & 83.1 \\
\hline \multicolumn{5}{|c|}{ Redionucl ides" } \\
\hline Total Alpho & 15 & 3.6 & 447 & 0.9 \\
\hline Total Beta & 20 & 2.5 & $7.1 E+03$ & 816 \\
\hline Redium $(226+228)$ & $5.0 E+00$ & & & \\
\hline Gross uranium-natural & $2.4 E+01$ & & & \\
\hline $3 \mathrm{H}$ & $2.0 E+04$ & & & \\
\hline${ }^{14} \mathrm{C}$ & NC & & & \\
\hline${ }^{60} \mathrm{Co}$ & $2.0 E+02$ & 1.14 & & \\
\hline${ }^{90} \mathrm{sr}$ & $8.6 \div 00$ & 1.14 & & \\
\hline${ }^{106} \mathrm{Ru}$ & $2.4 \overline{E+02}$ & & & \\
\hline$\pi / 35 n$ & $2.0 E+03$ & & & \\
\hline $729_{1}$ & $2.0 E+01$ & & & \\
\hline$\sqrt{137} \mathrm{Cs}$ & $1.2 E+02$ & & & \\
\hline T44 Ce/Pr & $2.8 E+02$ & & & \\
\hline $747 \mathrm{Pm}$ & $8.0 E+04$ & & & \\
\hline $234 \mathrm{U}$ & $2.0 E+01$ & 1.16 & & \\
\hline $235 u$ & $2.4 E+01$ & $1.3 E-01$ & & \\
\hline $238 \mathrm{Pu}$ & $1.6 E+00$ & & & \\
\hline $238 \mathrm{U}$ & $2.4 E+01$ & $8.7 E-01$ & & \\
\hline $239,240 \mathrm{Pu}$ & $1.2 E+00$ & $6.1 E \cdot 03$ & & \\
\hline $239,240 \mathrm{U}$ & $1.2 E+03$ & & & \\
\hline
\end{tabular}


Table 7-2. Comparison of $\mathrm{UO}_{3} / \mathrm{U}$ Plant Effluent Qualities and State Approved Land Disposal Structure Acceptance Criteria." ${ }^{\circ}$ (4 sheets)

\begin{tabular}{|c|c|c|c|c|}
\hline Analyte & $\begin{array}{c}\text { Acceptance } \\
\text { criterion }\end{array}$ & UNPUf & $\begin{array}{c}P^{\prime} C^{f} \\
\text { (Calc mode) }\end{array}$ & $\begin{array}{l}\text { PPC }^{\top} \\
\text { (standby } \\
\text { mode) }\end{array}$ \\
\hline \multicolumn{5}{|c|}{ Redionucl idese (cont'd) } \\
\hline $24 T_{A m}$ & $1.2 E+\infty$ & & & \\
\hline $241 \mathrm{Pu}$ & $8.0 \mathrm{E}+01$ & & & \\
\hline
\end{tabular}

Analyte concentrations represented by the 90 percent confidence interval limit (the upper (imit of the one-tailed 90 percent confidence interval for all dote sets) as reported in the appropriate strecm-specific report. Then -90 parcent confidence interval limit was not calculated, the moximm observed result is listed. Exception is PPC. Crene 1991.

Effluent concentrations expressed as micrograms/L unless indicated otherwise.

d gnitability temperatures are represented by the lower linit of the one-tailed confidence interval for all data sets.

Effluent concentrations for radionuclides expressed as picocuries/L.

Abbreviations used:

$U / U P H=V O_{3} / U P$ lant waste water

PPC = Plint process condensate

Calc = Calcination operations

standoy = Stardby mode

NC = no criteria

Reac = reactive

TDS = totel dissolved solids

TOC = total organic carbon

TOX = total organic halides

HS $=$ microsiemen

IC = fluoride analysis using ion chromatography technique

ISE = fluoride analysis using ion-specific electron technique

$\mathrm{CCH}=$ chlorocyclohexanol

NDMA $=$ nitrosool imethylamine. 
WHC-FP-0470-1

\subsection{HISTORICAL MONITORING/SAMPLING DATA FOR EFFLUENT STREAMS}

\subsection{AIR EFFLUENTS}

\subsubsection{Normal Conditions}

Historical air effluent monitoring and sampling data have been assembled in annual reports. These reports record the routine releases, unusual occurrences (i.e., upset conditions), sample points, analytical data sheets, instrument calibration records, and other information. The 1987 report represents data collected while the $\mathrm{UO}_{3}$ Plant was in standby mode. The $\mathrm{UO}_{3} \mathrm{Plant}$ is currently a transition to shutdown.

\section{Annual Reports}

R40, 1986a, Radioactivity in Gaseous Waste Discharged from the Separations Facilities During 1986, RHO-HS-SR-86-2 4QGASP, Rockwell Hanford Operations, Richland, Washington.

WHC, 1987, Effluent Releases and Solid Waste Management Report for 1987: 200/600/1100 Areas, WHC-EP-0141, Westinghouse Hanford Company, Richland, Washington.

WHC, 1989b, Effluent Discharges and Solid Waste Management Report for 1988: 200/600 Areas, WHC-EP-0141-1, Westinghouse Hanford Company, Richland, Washington.

WHC, 1990a, Effluent Discharges and Solid Waste Management Report for 1989: 200/600 Areas, WHC-EP-0141-2, Westinghouse Hanford Company, Richland, Washington.

WHC, 1992C, Environmental Releases for Calendar Year 1990, WHC-EP-0527, Westinghouse Hanford Company, Richland, Washington.

WHC, 1992d, Environmental Releases for Calendar Year 1991, WHC-EP-0527-1, Westinghouse Hanford Company, Richland, Washington.

WHC, 1993C, Environmental Releases for Calendar Year 1992, WHC-EP-0527-2, Westinghouse Hanford Company, Richland, Washington.

Pertinent information on the historical gaseous effluent monitoring may also be found in $\mathrm{UO}_{3}$ Gaseous Effluent Monitoring Plan, SD-CP-EMP-003, Rev. I (WHC 1989a).

Radionuclide effluent emission data for the 296-U-2, 296-U-4, and 296-U-13 stacks are summarized in Tables $8-1,8-2$, and $8-3$, respectively. The data was obtained from the following sources:

- 1990 release/concentration: WHC-EP-0527, Environmental Releases for Calendar Year 1990 
- 1991 release/concentration: WHC-EP-0527-1, Environmental Releases for Calendar Year 1991

- 1992 release: DOE/RL-93-36, Radionuclide Air Emissions Report for the Hanford Site Calendar Year 1992

\subsubsection{Upset Conditions}

Upset operating conditions for each stack were developed in Section 4.1.3.

\subsection{WATER EFFLUENTS}

\subsubsection{Normal Conditions}

Historical liquid monitoring and sampling data have been assembled in various reports. The effluent releases and solid waste management reports for 1987, 1988, and 1989 cited in Section 8.1. I list much of this information. Routine operations and releases, upsets, sample points, analytical data sheets, and other information typically are rccorded. The following reports contain additional historical data and transition to shutdown data.

RHO, 1986b, Radioactive Liquid Wastes Discharged to Ground in 200 Areas auring 1986, RHO-HS-SR-86-3 4QLIQP, Rockwell Hanford Operations, Richland, Washington.

WHC, 1989C, $\mathrm{UO}_{3}$ Liquid Effluent Monitoring Plan, SD-CP-EMP-005, Rev. 1, Westinghouse Hanford Company, Richland, Washington.

Tables 8-4(a-c) present liquid radioactive effluent releases for calendar years 1990, 1991, and 1992, respectively. These tables were obtained from the following sources: Environmental Releases for Calendar Year 1990 (WHC-EP0527); Environmental Releases for Calendar Year 1991 (WHC-EP-0527-1); and Environmental Releases for Calendar Year 1992 (WHC-EP-0527-2).

Table 8-5 presents radioactive effluent releases for the process condensate for calendar year 1992. The process condensate stream was inactive in 1990 and 1991.

\subsubsection{Upset Conditions}

Upset operating conditions for liquid discharge were given in Section 4.2.3. 
Table 8-1. Stack 296-U-2 Gaseous Radioactive Effluent Release Data.

\begin{tabular}{|l|c|c|c|c|}
\hline \multirow{2}{*}{ Radionuclide } & \multicolumn{2}{|c|}{1990} & \multicolumn{2}{c|}{1992} \\
\cline { 2 - 6 } & $\begin{array}{c}\text { Total } \\
\text { Release } \\
(\mathrm{Ci})\end{array}$ & $\begin{array}{c}\text { Ave Conc } \\
(\mu \mathrm{Ci} / \mathrm{mL})\end{array}$ & $\begin{array}{c}\text { Total } \\
\text { Release } \\
(\mathrm{Ci})\end{array}$ & $\begin{array}{c}\text { Ave Conc } \\
(\mu \mathrm{Ci} / \mathrm{mL})\end{array}$ \\
\hline Total alpha & ND & $-4.0 \mathrm{E}-13$ & $1.2 \mathrm{E}-07$ & $1.85 \mathrm{E}-14$ \\
\hline Total Beta & $2.3 \mathrm{E}-06$ & $2.2 \mathrm{E}-12$ & $1.3 \mathrm{E}-07$ & $2.0 \mathrm{E}-14$ \\
\hline Volume (L) & \multicolumn{2}{|c|}{$1.0 \mathrm{E}+09 \mathrm{~L}$} & \multicolumn{2}{|c|}{$6.5 \mathrm{E}+09 \mathrm{~L}$} \\
\hline
\end{tabular}

Stack 296-U-2 exhausted a total of 26 hours in 1991 for testing. No sample was collected.

ND = not detected

Table 8-2. Stack 296-U-04 Gaseous Radioactive Effluent Emissions Data.

\begin{tabular}{|l|c|c|c|c|c|c|}
\hline \multirow{2}{*}{ Radionuclide } & \multicolumn{2}{|c|}{1990} & \multicolumn{2}{c|}{1991} & \multicolumn{2}{c|}{1992} \\
\cline { 2 - 8 } & $\begin{array}{c}\text { Total } \\
\text { Release } \\
(\mathrm{Ci})\end{array}$ & $\begin{array}{c}\text { Ave Conc } \\
(\mu \mathrm{Ci} / \mathrm{mL})\end{array}$ & $\begin{array}{c}\text { Total } \\
\text { Release } \\
(\mathrm{Ci})\end{array}$ & $\begin{array}{c}\text { Ave Conc } \\
(\mu \mathrm{Ci} / \mathrm{ml})\end{array}$ & $\begin{array}{c}\text { Total } \\
\text { Release } \\
(\mathrm{Ci})\end{array}$ & $\begin{array}{c}\text { Ave Conc } \\
(\mu \mathrm{C} i / \mathrm{ml})\end{array}$ \\
\hline${ }^{90} \mathrm{Sr}$ & $4.4 \mathrm{E}-05$ & $8.1 \mathrm{E}-13$ & $8.0 \mathrm{E}-08$ & $2.3 \mathrm{E}-15$ & $5.4 \mathrm{E}-08$ & $1.7 \mathrm{E}-15$ \\
\hline${ }^{137} \mathrm{Cs}$ & $7.1 \mathrm{E}-07$ & $1.3 \mathrm{E}-14$ & $\mathrm{ND}$ & $<1.8 \mathrm{E}-14$ & $3.8 \mathrm{E}-07$ & $1.2 \mathrm{E}-14$ \\
\hline Total U & $1.0 \mathrm{E}-11$ & $1.9 \mathrm{E}-19$ & $3.0 \mathrm{E}-06$ & $8.8 \mathrm{E}-14$ & $9.4 \mathrm{E}-07$ & $2.9 \mathrm{E}-14$ \\
\hline${ }^{239,240 \mathrm{Pu}}$ & $7.1 \mathrm{E}-08$ & $1.3 \mathrm{E}-15$ & $1.6 \mathrm{E}-07$ & $4.6 \mathrm{E}-15$ & $4.02 \mathrm{E}-08$ & $1.25 \mathrm{E}-15$ \\
\hline${ }^{241} \mathrm{Am}$ & $\mathrm{ND}$ & $<1.8 \mathrm{E}-15$ & $\mathrm{ND}$ & $<3.2 \mathrm{E}-15$ & $\mathrm{ND}$ & $<3.2 \mathrm{E}-15$ \\
\hline Total alpha & $9.6 \mathrm{E}-06$ & $1.8 \mathrm{E}-13$ & $7.9 \mathrm{E}-06$ & $2.3 \mathrm{E}-15$ & $9.8 \mathrm{E}-07$ & $2.1 \mathrm{E}-14$ \\
\hline Total Beta & $1.25 \mathrm{E}-05$ & $2.3 \mathrm{E}-13$ & $1.3 \mathrm{E}-05$ & $3.8 \mathrm{E}-13$ & $2.3 \mathrm{E}-06$ & $5.1 \mathrm{E}-14$ \\
\hline Volume (L) & \multicolumn{2}{|c|}{$5.4 \mathrm{E}+10 \mathrm{~L}$} & \multicolumn{2}{|c|}{$3.4 \mathrm{E}+10 \mathrm{~L}$} & $3.2 \mathrm{E}+10 \mathrm{~L}$ \\
\hline
\end{tabular}

ND $=$ not detected 
HHC-EP-0470-1

Table 8-3. Stack 296-U-13 Gaseous Radioactive Effluent Emissions Data.

\begin{tabular}{|l|c|c|c|c|c|}
\hline \multirow{2}{*}{ Radionuclide } & \multicolumn{2}{|c|}{1990} & \multicolumn{2}{c|}{1991} & 1992 \\
\cline { 2 - 7 } & $\begin{array}{c}\text { Total } \\
\text { Release } \\
(\mathrm{Ci})\end{array}$ & $\begin{array}{c}\text { Ave Conc } \\
(\mu \mathrm{C} \text { / } / \mathrm{mL})\end{array}$ & $\begin{array}{c}\text { Total } \\
\text { Release } \\
(\mathrm{Ci})\end{array}$ & $\begin{array}{c}\text { Ave. Conc. } \\
(\mu \mathrm{Ci} / \mathrm{ml})\end{array}$ & $\begin{array}{c}\text { Total } \\
\text { Release } \\
(\mathrm{Ci})\end{array}$ \\
\hline Total alpha & $3.7 \mathrm{E}-09$ & $2.1 \mathrm{E}-15$ & $3.7 \mathrm{E}-09$ & $2.1 \mathrm{E}-15$ & ND \\
\hline Total Beta & $1.8 \mathrm{E}-08$ & $1.0 \mathrm{E}-14$ & $1.8 \mathrm{E}-08$ & $1.0 \mathrm{E}-14$ & ND \\
\hline Volume (L) & \multicolumn{2}{|c|}{$1.7 \mathrm{E}+09 \mathrm{~L}$} & \multicolumn{2}{|c|}{$1.7 \mathrm{E}+09 \mathrm{~L}$} & $4.2 \mathrm{E}+09 \mathrm{~L}$ \\
\hline
\end{tabular}

ND = not detected

Table 8-4a. UO, Plant to 216-U-14 Ditch, 200 West Area (H102), Calendar Year 1990.

\begin{tabular}{|c|c|c|}
\hline Radionucl ide & $\begin{array}{c}\text { Release } \\
(\mathrm{Ci})\end{array}$ & $\begin{array}{c}\text { Average } \\
\text { Concentration } \\
(\mu \mathrm{Ci} / \mathrm{ml})\end{array}$ \\
\hline${ }^{3} \mathrm{H}$ & $2.0 \mathrm{E}-01$ & $9.3 \mathrm{E}-07$ \\
\hline${ }^{90} \mathrm{Sr}$ & $3.3 \mathrm{E}-03$ & $1.6 \mathrm{E}-08$ \\
\hline${ }^{99} \mathrm{TC}$ & $\mathrm{ND}$ & $<2.0 \mathrm{E}-07$ \\
\hline${ }^{137} \mathrm{CS}$ & $1.5 \mathrm{E}-02$ & $7.1 \mathrm{E}-08$ \\
\hline Gross U & $2.9 \mathrm{E}-04$ & $1.4 \mathrm{E}-09$ \\
\hline${ }^{239}{ }^{240} \mathrm{Pu}$ & $2.0 \mathrm{E}-03$ & $9.6 \mathrm{E}-09$ \\
\hline${ }^{241} \mathrm{Am}$ & $4.2 \mathrm{E}-03$ & $.0 \mathrm{E}-08$ \\
\hline Gross $\alpha$ & $6.6 \mathrm{E}-04$ & $3.1 \mathrm{E}-09$ \\
\hline Gross B & $2.0 \mathrm{E}-03$ & $9.4 \mathrm{E}-09$ \\
\hline Volume & $2.1 \mathrm{E}+08 \mathrm{~L}$ \\
\hline ND - None detected.
\end{tabular}


Table 8-4b. Radionuclides in $\mathrm{UO}_{3} \mathrm{Pl}$ ant to 216-U-14 Ditch, 200 West Area (H1O2) in 1991.

\begin{tabular}{|c|c|c|}
\hline Radionuclide & $\begin{array}{c}\text { Release } \\
(\mathrm{Ci})\end{array}$ & $\begin{array}{c}\text { Average } \\
\text { Concentration } \\
(\mu \mathrm{Ci} / \mathrm{ml})\end{array}$ \\
\hline${ }^{3} \mathrm{H}$ & $2.1 \mathrm{E}-00$ & $6.0 \mathrm{E}-06$ \\
\hline${ }^{90} \mathrm{Sr}$ & $9.5 \mathrm{E}-03$ & $2.0 \mathrm{E}-08$ \\
\hline${ }^{99} \mathrm{TC}$ & $9.2 \mathrm{E}-02$ & $2.7 \mathrm{E}-07$ \\
\hline${ }^{137} \mathrm{Cs}$ & ND & $<5.3 \mathrm{E}-08$ \\
\hline U, Total & $2.9 \mathrm{E}-02$ & $8.5 \mathrm{E}-08$ \\
\hline${ }^{239},{ }^{240} \mathrm{Pu}$ & ND & $<2.1 \mathrm{E}-08$ \\
\hline${ }^{241} \mathrm{Am}$ & ND & $<2.7 \mathrm{E}-08$ \\
\hline Total $\alpha$ & $9.8 \mathrm{E}-03$ & $2.9 \mathrm{E}-08$ \\
\hline Total B & $1.3 \mathrm{E}-02$ & $3.7 \mathrm{E}-08$ \\
\hline Volume & \multicolumn{2}{|c|}{$3.4 \mathrm{E}+08 \mathrm{~L}$} \\
\hline
\end{tabular}

ND - None detected.

Table 8-4c. Radionuclides in $\mathrm{UO}_{3}$ Plant Discharges (207-U) to 216-U-14 Ditch, 200 West Area (H102) in 1992.

\begin{tabular}{|c|c|c|}
\hline Radionuclide & $\begin{array}{c}\text { Release } \\
(\mathrm{Ci})\end{array}$ & $\begin{array}{c}\text { Average } \\
\text { Concentration } \\
(\mu \mathrm{Ci} / \mathrm{ml})\end{array}$ \\
\hline${ }^{3 \mathrm{H}}$ & $6.0 \mathrm{E}-0$ & $2.2 \mathrm{E}-06$ \\
\hline${ }^{90} \mathrm{Sr}$ & $3.6 \mathrm{E}-0$ & $1.3 \mathrm{E}-08$ \\
\hline${ }^{99} \mathrm{TC}$ & $5.9 \mathrm{E}-0$ & $2.1 \mathrm{E}-07$ \\
\hline${ }^{137} \mathrm{CS}$ & ND & $<4.6 \mathrm{E}-08$ \\
\hline$U$, Total & $4.5 \mathrm{E}-0$ & $1.6 \mathrm{E}-08$ \\
\hline${ }^{239},{ }^{240} \mathrm{Pu}$ & $\mathrm{ND}$ & $<2.6 \mathrm{E}-08$ \\
\hline${ }^{241} \mathrm{Am}$ & $\mathrm{ND}$ & $<2.9 \mathrm{E}-08$ \\
\hline Total $\alpha$ & $1.2 \mathrm{E}-0$ & $4.2 \mathrm{E}-08$ \\
\hline Total B & $4.5 \mathrm{E}-0$ & $1.6 \mathrm{E}-08$ \\
\hline Flow & $2.8 \mathrm{E}+08 \mathrm{~L}(7.3 \mathrm{E}+07 \mathrm{gal})$ \\
\hline ND & &
\end{tabular}

ND - None detected. 
Table 8-5. Radionuclides in Uranium-0xide Plant Process Condensate Discharges (U-17), to 216-U-17 Crib, 200 West Area, in 1992 (H126).

\begin{tabular}{|c|c|c|}
\hline Radionuclide & $\begin{array}{c}\text { Release } \\
(\mathrm{Ci})\end{array}$ & $\begin{array}{c}\text { Average Concentration } \\
(\mu \mathrm{Ci} / \mathrm{ml})\end{array}$ \\
\hline${ }^{3} \mathrm{H}$ & $5.2 \mathrm{E}-01$ & $5.3 \mathrm{E}-04$ \\
\hline${ }^{99} \mathrm{TC}$ & $4.1 \mathrm{E}-04$ & $4.1 \mathrm{E}-07$ \\
\hline$U$, Total & $1.2 \mathrm{E}-04$ & $1.2 \mathrm{E}-07$ \\
\hline${ }^{239,}{ }^{240} \mathrm{Pu}$ & ND & $<1.5 \mathrm{E}-08$ \\
\hline${ }^{241} \mathrm{Am}$ & ND & $<3.0 \mathrm{E}-08$ \\
\hline Total $\alpha$ & $1.4 \mathrm{E}-04$ & $1.4 \mathrm{E}-07$ \\
\hline Total B & $5.2 \mathrm{E}-04$ & $5.3 \mathrm{E}-07$ \\
\hline Flow & \multicolumn{2}{|c|}{$9.9 \mathrm{E}+05 \mathrm{~L}(2.6 \mathrm{E}+05 \mathrm{gal})$} \\
\hline
\end{tabular}

ND - None detected. 


\subsection{SAMPLE ANALYSIS}

\subsection{ANALYTICAL LABORATORY AND PROCEDURES}

Requirements for the development, issuance, and control of instructions and procedures within the Analytical Laboratories are covered by WHC-CM-5-4, Analytical Chemistry Services Laboratories Operating Instructions (WHC 1993D). This procedure is an administrative procedure which provides guidance on how to write, review, and control analytical procedures and other supporting procedures used within the analytical laboratories.

The analytical laboratories presently have over 1,000 procedures that define operations. These procedures, individually numbered and controlled, are divided into six categories as shown below:

1. LA Series - Analytical Procedures. These procedures cover a specific analysis or analysis type for each sample.

2. Lo Series - Operating Procedures. These procedures provide guidance for all laboratory operations supporting analytical techniques. This would include such operations as packaging, shipping, etc.

3. LE Series - Essential Materials Procedures. These procedures cover the analysis of supplies, chemicals, and metals using industry standard analyses such as American Society for Testing and Materials (ASTM) procedures.

4. LR Series - Reagent Procedures. These procedures provide guidance for the preparation, dilution and storage of standards and reagents used in specific Analytical Procedures (LA Series).

5. LC Series - Computer Operation Procedures. These procedures cover the use of database systems and computer operations associated with specific analysis techniques.

6. LQ Series. These procedures cover the techniques used for $Q C$ guidance, calibration and verification of analysis techniques and analytical systems.

Each Analytical Procedure (LA Series) covers a specific analysis for a variety of sample types. The procedures are individually numbered, issued, and controlled by the Procedure Control Group. Each procedure is a "controlled" document and contains the following information:

- Title

- Author

- Issued by

- Laboratory manager

- Release date

- Review date

- Document number

- Revision/Modification

- Page number. 
Each procedure contains the following generic sections as applicable to the specific analysis technique:



Additional requirements are defined in PUREX/UO 3 Plant Administration, WHC-CM-5-9 (WHC 1993e). These procedures define operations not covered by existing codes and standards and contain all necessary requirements for qualifying personnel, procedures, and/or equipment to conduct processes in a timely, competent manner. Analytical Laboratory operating instructions al so cover the preparation, documentation, and control of individual procedures.

Quality Assurance requirements for the Analytical Laboratory procedures are defined by the following documents:

- WHC-CM-4-2, Westinghouse Quality Assurance Manual (WHC 1993f)

- WHC-CM-5-9, PUREX $/ \mathrm{UO}_{3}$ Plant Administration (WHC 1993e)

The 222-S Laboratory on the Hanford Site has one program $p l a n$ and two project plans to address applicable quality requirements related to sample analysis. These plans are as follows:

- WHC-SD-CP-QAPP-003, Quality Assurance Program Plan for the Chemical Analyses of Environmental Samples (WHC 1990b).

- WHC-SD-QAPP-001, Analytical Chemistry Services Laboratories Quality Assurance Plan (WHC 1993f).

- WHC-SD-CP-QAPP-002, Quality Assurance Project Plan for the Chemical Analysis of Highly Radioactive Mixed Waste Samples in Support of Environmental Activities on the Hanford Site (WHC 1989b).

The Resources Conservation and Recovery Act of 1976 (RCRA) protocol for liquid effluent sampling, associated with the liquid effluent study, is not part of the FEMPs. The QA requirements for the sampling analysis pians (SAP) associated with the liquid effluent study are ident ified in the latest version of the WHC-SD-WM-QAPP-011, Liquid Effluent Sampling Quality Assurance Project Plan (WHC 1991b).

Details of the analytical laboratory and analytical procedures are discussed in the 222-S Laboratory FEMP. 
The analytical and laboratory procedure for the FEMP activities are identified in Quality Assurance Project Plan for Facility Effluent Monitoring Plan (WHC 1992b). General requirements for laboratory procedures, data analyses, and statistical treatment are addressed in the Quality Assurance Project Plan (QAPJP).

The following elements are contained in the 222-S Laboratory Analytical Procedures (identified in QAPJP, WHC-EP-0446, Table 8-1).

- Procedures preventing crosscontamination

- Documentation of Methods

- Gamma emitting radionuclides

- Calibration

- Handling of samples

- Analysis method and capabilities

- Gross alpha, beta, and gamma measurements

- Direct gamma-ray spectrometry

- Beta counters

- Alpha-energy analysis

- Radiochemical separation procedures

- Reporting of results

- Counter calibration

- Intercalibration of equipment and procedures

- Counter background

- Quality assurance

- Summary of data and statistical treatment requirements

- Variability of effluent and environmental data

- Summarization of data and testing for outliers

- Treatment of significant figures

- Parent-decay product relationships 
- Comparisons to regulatory or administrative control standards and control data

- Quality assurance

\subsection{SAMPLE AND DATA CHAIN OF CUSTOOY}

Sample identification is initiated by the operations group taking the sample. Sampling personnel use the chain of custody form and "log in" system to provide sample identification. Sample custody is transferred when the properly marked sample is received by the analytical laboratory.

Sample chain of custody within the Analytical Laboratory is covered by WHC-CM-5-4, Analytical Chemistry Services Laboratories Operating Instructions (WHC 1993d) and individual analytical laboratory procedures.

$\mathrm{UO}_{3}$-acility has a chain-of-custody procedure for Stack Record Air Samples. This procedure is WHC-IP-0718, Section 3.3.3, "Automated Bar Coding of Air Samples at Hanford (ABCASH)." 






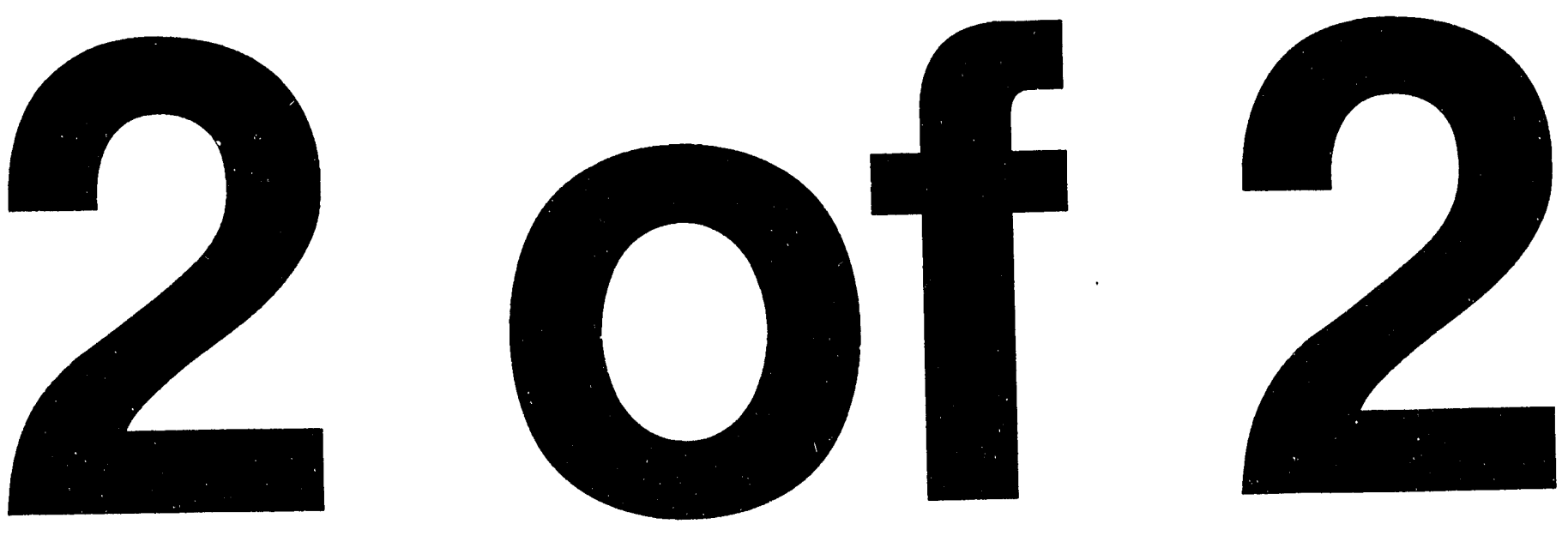


\subsection{NOTIFICATION AND REPORTING REQUIREMENTS}

Notification and reporting requirements are imposed by federal and state law as well as by DOE Orders. Because DOE and EPA documents are periodically updated, the current requirements should be obtained from the latest CFR, DOE order, etc. This section is to serve as a guideline for general notification and reporting requirements and as a reference to the sources where specific information may be found for federal, state and DOE requirements.

\subsection{OCCURRENCE CATEGORIZATION, NOTIFICATION, AND REPORTING}

Notifications and reporting of specific events related to environmental releases and/or events involving effluents and/or hazardous materials shall be made as per DOE Orders 5400.1 (DOE 1991a) and 5000.3B (1993b). Implementation of the Orders is accomplished via Management Requirements and Procedures Manual. Specific implementation, where required, is included in the appropriate Facility's "Occurrence Categorization, Notification, and Reporting" procedure. Implementation of environmental limits and requirements is found in the Environmental Compliance Manual, WHC-CM-7-5 (WHC 1993e).

\subsubsection{Occurrence Identification and Immediate Response}

Each employee shall identify events and conditions and shall promptly notify management of such occurrences.

a. Call 911 if immediate help such as fire, ambulance, or patrol is required.

b. Call 373-3800 (the Patrol Operations Center) if assistance other than fire, ambulance, or patrol is required.

c. After requesting necessary outside assistance, the employee shall notify his or her supervisor, who shall notify the facility manager, the building emergency director, and the Occurrence Notification Center (376-2900).

Operations personnel shall take appropriate immediate action to stabilize or return the facility/operation to a safe condition. Actions taken in response to non-routine releases, as evidenced by high sample results from liquid and gaseous effluent sampling, are documented in PUREX $/ \mathrm{UO}_{3}$ Plant Administration, WHC-CM-5-9 (WHC 1993e).

The oversight organizations shall notify their DOE Field office, Richland, counterparts of the event after receiving notifications from, and discussing the event with, the facility manager. 


\subsubsection{Occurrence Categorization}

Occurrences (environmental) shall be categorized as soon as practical using the specific criteria listed in Section 10.2 for radioactive and hazardous materials release. These categorizations should be made within 2 hours of identification. Occurrences shall be categorized by their seriousness; if categorization is not clear, the occurrence shall be initially categorized at the higher level being considered. The occurrence categorization shall then be either evaluated, maintained, or lowered as information becomes available.

\subsection{OCCURRENCE CATEGORIZATION}

The following criteria for categorization of occurrences are established in WHC-CM-1-3, Ident ifying and Resolving Unreviewed Safety Questions

(WHC 1989d), which implements the requirements contained in DOE Order $5000.3 B$ (DOE 1993b).

\subsubsection{Radioactive Releases}

\subsubsection{Emergency.}

- Any release of radionuclide material to controlled or uncontrolled areas in concentration which, if averaged over a 24-hour period, would exceed 5 times the respective reportable quantities specified for such materials in 40 CFR 302 (EPA 1991b). Note: This event must also meet the criteria for classified emergency in accordance with Emergency Plan, WHC-CM-4-1 (WHC 1989e), and/or facility specific emergency action levels.

\subsubsection{Unusual Occurrence.}

- Release of a radionuclide material that exceeds a federally permitted release by the amount of a CERCLA reportable quantity or, where no federally permitted release exists, the release exceeds the reportable quantity.

- Release of radionuclide material that violates environmental requirements in federal permits, federal regulations, or DOE standards.

- Release below Emergency levels which requires immediate (less than 4 hours) reporting to Federal regulatory authorities or triggers specific action levels for an outside agency.

\subsubsection{Off-Normal.}

- Any release of radionuclide material to controlled or uncontrolled areas that is not part of a normal monitored release and exceeds 50 percent of a CERCLA reportable quantity specified for such material in accordance with 40 CFR 302 (EPA 199lb). 
- Any controlled release of radionuclide material that occurs as a monitored part of normal operations which exceeds what historical data and/or analysis show is expected as a result of normal operations.

- Any monitored facility or site boundary where exposure of concentrations exceed what historical data and/or analys is show is expected as a result of normal operations.

- Any detection of a radionuclide in a sanitary or storm sewer, waste or process stream, or any holding points where such a material is not expected.

- Any controlled, uncontrolled, or accidental release which is not classified as an unusual occurrence but which will be reported in writing to state/local agencies in a format other than routine monthly or quarterly reports. Note: This does not include routine offsite distribution of Notification Reports.

\subsubsection{Release of Hazardous Substances/Regulated Pollutants/0il}

\subsubsection{Emergency.}

- Any actual or potential release of material to the environment that results in, or could result in, significant off-site consequences (e.g., need to relocate people, major wildlife kills, major wetland degradation, major aquifer contamination, need to secure downstream water supply intakes, etc.). Note: This event must also meet the criteria for classified emergency in accordance with WHC-CM-4-1 (WHC 1989e), and/or facility specific emergency action levels.

- Any release of hazardous substances or regulated pollutants in concentrations which exceed 5 times the respective reportable quantities specified for such materials in 40 CFR 302 EPA (1991b). Note: This event must also meet the criteria for classified emergency in accordance with WHC-CM-4-1 (WHC 1989e), and/or facility specific emergency action levels.

10.2.2.2 Unusual Occurrence.

- Release of a hazardous substance or regulated pollutant that exceeds a CERCLA reportable quantity per 40 CFR 302 (EPA 1991b) or exceeds a federally permitted release by a reportable quantity.

- Release of a hazardous substance, regulated pollutant, or oil that violates environmental requiremencs in Federal permits, Federal regulations, or DOE standards. 
- Release below emergency levels that requires immediate (less that 4 hours) reporting to Federal regulatory agencies or triggers specific levels for an outside federal agency.

- Any release of 100 gallons or more of oil.

\subsubsection{Off-Normal.}

- Release of a hazardous substance or regulated pollutant to controlled or uncontrolled areas that is not part of a normal, monitored release and exceeds 50 percent of a CERCLA reportable quantity as specified for such material in accordance with 40 CFR 302 (EPA 1991b).

- Any release of oil less than unusual occurrence levels but greater than 10 gallons.

- Any detection of a toxic or hazardous substance in a sanitary or storm sewer, waste or process stream, $r$ any holding points where such a material is not expected.

- Any controlled, uncontrolled, or accidental release which is not classified as an unusual occurrence but which will be reported in writing to state/local agencies in a format other than routine monthly or quarterly reports. Note: This does not include routine offsite distribution of notification reports.

- Any controlled release of hazardous/regulated material that occurs as a monitored part of normal operations which exceeds what historical data and/or analysis shows is expected as a result of normal operations.

- Any general environmental monitoring where concentration increases to a level which exceeds what historical data and/or anaiysis shows is expected as a result of normal operations.

\subsubsection{Discovery of Hazardous Material Contamination} Due to DOE Operations

\subsubsection{Emergency.}

- Discovery of contamination that results or could result in significant consequences (i.e. exceeding safe exposure limits to workers or public). Note: This event must al so meet the criteria for classified emergency in accordance with WHC-CM-4-1 (WHC 1989e) and/or facility specific emergency action levels.

- Discovery of on-site or off-site hazardous material contamination in concentrations that exceed 5 times the respective reportable quantities specified for such materials in 40 CFR 302 (EPA 1991b). Note: This event must also meet the criteria for classified emergency in accordance with WHC-CM-4-1 (WHC 1989e) and/or facility specific emergency action levels. 


\subsubsection{Unusual Occurrence.}

- Discovery of onsite or offsite contamination due to DOE operations which does not represent an immediate threat to the public, that exceeds a reportable quantity for such materials in accordance with 40 CFR 302 (EPA 1991b).

- Any discovery of groundwater contamination that is not part of an existing plume previously identified either in an annual report or in any CERCLA/RCRA activity or report.

\subsubsection{Off-Normal.}

- Discovery of onsite contamination attributable to DOE operations that exceeds 50 percent of a reportable quantity for such material in accordance with 40 CFR 302 (EPA 1991b).

\subsubsection{Agreement/Compliance Activities}

\subsubsection{Unusual Occurrence.}

- Any agreement, compliance, remediation, or permit-mandated activity for which formal notification has been received from the relevant regulatory agency that a site plan is not satisfactory, or that a site is considered to be in noncompliance with schedules or requirements. Note: Formal notification must be received by WHC in writing.

- Any occurrence under any agreement or compliance area that requires notification of an outside regulatory agency within 4 hours or less, or triggers an outside regulatory agency action level, or otherwise indicates specific interest/concern from such agencies. Note: This does not i.lclude notifications made for radionuclide/hazardous material releases that are less than 50 percent of the reportable quantity as specified in 40 CFR 302 (EPA 1991b).

\subsubsection{Off-Normal.}

- Any occurrence under any agreement or compliance area that will be reported in writing to outside agencies in a format other than routine monthly or quarterly reports. Note: This does not include routine offsite distribution of notification reports.

\subsubsection{Ecological Resources}

\subsubsection{Unusual Occurrence.}

- Any occurrence causing significant impact to any ecological resource for which the DOE is a trustee (i.e. destruction of a critical habitat, damage to an historical/archeological site, and damage to wetlands. 


\subsection{FEDERAL REQUIREMENTS}

\subsubsection{Resource Conservation and Recovery Act of 1976}

The RCRA requires biennial reports to be submitted to the regional administrator of EPA. The 40 CFR 262, Subpart D (EPA 1988a), sets forth the reporting requirements for generators nf hazardous waste that ship waste offsite, or store, treat, or dispose 0 , hazardous waste onsite.

Owners or operators of treatment, storage, or disposal (TSD) facilities must comply with the reporting requirements contained in 40 CFR 264, Subpart $E$ (EPA 1988b) and 40 CFR 265, Subpart E (EPA 1988c).

\subsubsection{Comprehensive Environmental Response, Compensation and Liabi'ity Act of 1980}

The 40 CFR 302 (EPA 1991C) contains reportable quantities and notification requirements for releases of hazardous substances as designated by CERCLA and the Clean Water Act.

\subsubsection{National Emission Standards for Hazardous Air Pollutants}

Compliance and reporting requirements for DOE facilities emitting radionuclides other than Radon are contained in 40 CFR 61, Subpart $H$ (EPA 1991a). The NESHAP requires that an annual report be submitted to EPA headquarters and the appropriate regional office.

\subsection{STATE REQUIREMENTS}

\subsubsection{Generator Reporting}

Generator reporting requirements are found in WAC 173-303-220

(WAC 1991a). The state requires that annual reports covering the preceding year be submitted by March 1 to Ecology.

\subsubsection{Facility Reporting}

Owners or operators of TSD facilities are also required to prepare and submit annual reports. These must be submitted by March 1 and cover facility activities for the previous year. The specific content requirements are specified in WAC 173-303-390 (WAC 1991a).

Effluents from the $\mathrm{UO}_{3} \mathrm{Plant}$ during the transition to shutdown do not contain hazardous or dangerous wastes; therefore, $\mathrm{UO}_{3}$ Plant operations are not subject to RCRA or the Washington State Dangerous Waste Regulations, WAC 173-303, (WAC 199la) reporting requirements. DOE and Westinghouse Hanford 
have to comply with the above federal and state reporting requirements if and when the facility operations change and discharges (either liquid or gaseous) from the $\mathrm{UO}_{3}$ Plant contain a hazardous or dangerous waste containment.

\subsection{U.S. DEPARTMENT OF ENERGY REQUIREMENTS}

\subsubsection{U.S. Department of Energy Order 5400.1, Chapter II General Environmental}

Protection Program - Notification and Reports

Consistent with the notification requirements contained in DOE Orders 5484.1 (DOE 1983), 5000.3B (DOE 1993b) and the DOE 5500 series, field organizations shall notify the Emergency Operations Center (EOC) of the significant nonroutine releases of any pollutant or hazardous substance.

A11 DOE facilities that conduct significant environmental protection programs shall prepare an Annual Site Environmental Report. Annual summary reports on environmental occurrences shall be included in the Annual Site Environmental Report. Suggested content and format for the Annual Site Environmental Report are contained in DOE Order 5400.1 (DOE 1991a).

The DOE Order 5400.1 also requires that a Radioactive Effluent and Onsite Discharge Data Report, covering the previous calendar year be submitted to the Waste Information Systems Branch, EG\&G Idaho, in Idaho Falls, Idaho 83415, by April 1. Unplanned releases of radioactive material in effluents, whether onsite or offsite, shall also be reported. The content and forms to be used for these reports are contained in DOE Order 5400.1, Chapter II.

\subsubsection{U.S. Department of Energy Order 5484.1 Environmental Protection, Safety and Health Protection Information Reporting Requirements}

Annual Radiation Exposure Reports for the preceding calendar year are required to be subinitted to the System Safety Development Center by March 31. Content and form requirements are in Chapter IV of this order.

The DOE Order 5484.1 also requires radiation exposures of individuals that exceed the specified limits in one calendar quarter to be reported in the form of a memorandum to the Operational and Environmental Safety Division. Radiation exposure limits are listed in Chapter II of this order.

Events that occur in the facility and adversely affect operations, personnel safety, or DOE requirements should receive a thorough investigation and an investigation report should be prepared. The DOE Order 5484.1 (DOE 1983) sets forth occurrences requiring investigation as well as the investigation requirements as determined by the severity of the occurrence, investigation report format, and content outlines. 
The RL Order 5484.1 contains the following requirements for the implementation of DOE Order 5484.1 at the Hanford Site. Contractors shall, at a minimum, make oral notification to the appropriate RL program division or office, to the Public Affairs Office (PAO), and to Safety and Quality Assurance (SQA) or the SQA duty officer as soon as it is apparent that an incident may meet the criteria of a Type A or Type B occurrence. A listing of occurrences requiring a Type $A$ or Type $B$ investigation is contained in Chapter I of DOE Order 5484.1.

Contractors are required to verbally notify responsible SQA environmental protection officials within 24 hours of becoming aware of any of the following occurrences:

- Violation of applicable federal, state or local pollution control standards and requirements.

- Any noncompliance with the terms and/or conditions of an existing National Pollutant Discharge El imination system (NPDES) permit, PSD permit, or any other environmental protection based permit or formal agreement with an applicable regulatory body.

- Any gaseous or liquid radiological effluent releases which exceed DOE requirements and/or contractor specific radiological release concentration guides. 


\subsection{INTERFACE WITH THE OPERATIONAL ENVIRONMENTAL MONITORING PROGRAM}

\subsection{DESCRIPTION}

The sitewide Environmental Monitoring PIan (EMP), as described in the FEMP Management Plan (WHC 1991g), consists of two distinct but related components; environmental surveillance conducted by PNL and effluent monitoring conducted by WHC. The responsibilities for these two portions of the EMP are delineated in a Memorandum of Understanding (MOU 1989). Environmental surveillance, conducted by PNL, consists of surveiliance of all environmental parameters to demonstrate compliance with regulations. Effluent monitoring includes both in-line and facility effluent monitoring as well as near-field (near-facility) operational environmental monitoring. Projected EDEs, reported in this FEMP, are the products of in-line effluent monitoring. Near-field monitoring is required by section 5.4, "Environmental Monitoring," Environmental Compliance Manual (WHC 1993), and procedures described in Operational Environmental Monitoring (WHC 1992a).

\subsection{PURPOSE}

The purpose of the Operational Environmental Monitoring Program (OEMP) is to provide facility-specific environmental monitoring to protect the environment adjacent to facilities under the responsibility of WHC and assure compliance with WHC requirements and local, state, and federal environmental regulations.

The objectives of the OEMP are to evaluate the following:

- Compliance with DOE, EPA, Ecology, WDOH, and internal WHC environmental radiation protection requirements and guides

- Performance of radioactive waste confinement systems

- Trends of radioactive materials in the environment at and adjacent to nuclear facilities and waste disposal sites.

Specifically, the OEMP is developed to:

- Monitor all inactive, existing, and new low-level waste (LLW) disposal sites to assess both radiological and nonradiological hazards (DOE Order 5820.2A).

- Determine the effectiveness of effluent treatment and controls in reducing effluents and emissions (DOE/EH-0173T, Page 1-1, Par. 1) (DOE/EV/1830-T5).

- Detect and quantify unplanned releases (DOE/EH-0173T, Page 1-1, Par. 2) (40 CFR 302) (WAC 173-303-145) (DOE 5000.3B) (DOE 5484.1). 
- Monitor fugitive emissions and diffuse sources from contaminated areas for compliance with NESHAP (40 CFR 61), (DOE/EH-0173T, $\mathrm{Pg}$. 3-4, 3.3.2), Toxic Air Emissions Inventory (40 CFR 265, Subparts $A A \& B 13)$, State Operating Permit Program (40 CFR 70), and Source Registration (WAC 246-247).

- Monitor all surplus facilities prior to decontaminating or decommissioning (DOE Order 5820.2A).

- Monitor new and existing sites, processes, and facilities for potential impacts and releases (DOE Order 5484.1 and DOE/EH-0173T).

- Monitor and assess radioactive contamination and potential exposure to employees and the public (DOE Orders 5400.1 \& 5400.5).

The purpose and justification for the OEMP is contained in WHC-CM-7-4, Operational Environmental Monitoring, WHC-CM-7-5, Environmental Compliance. The primary justification for the OEMP include the following:

- The OEMP provides a level of assurance to WHC that the effluent and contamination controls for the various facilities and waste sites are effective.

- The OEMP monitors a diversity of operations, activities, and programs managed by several different WHC organizations. Accordingly, the program direction and integration function performed by Environmental Engineering Studies (EES) is needed to assure program consistency, technical quality, and cost effectiveness.

- A secondary aspect of the OEMP is additional assurance beyond that provided by the Occupational Health and Safety Program that it is "OK" to work onsite and for visitors to safely tour the site.

\subsection{BASIS}

Near-field environmental surveillance is conducted to (1) monitor employee protection; (2) monitor environmental protection; and (3) ensure compliance with local, State, and Federal regulations. Compliance with parts of the following DOE orders, 40 CFRs, and WACs are addressed through this activity.

- DOE Order 5000.3B, Occurrence Reporting and Processing of Operational Information

- DOE Order 5400.1, General Environmental Protection Program

- DOE Order 5400.5, Radiation Protection of the Public and the Environment

- Order 5484.1, Protection, Safety, and Health Protection Information Reporting System

- Order 5820.2A, Radioactive Waste Mc lagement 
- DOE/EH-0173T, Environmental Regulatory Guide for Radiological Effluent Monitoring and Environmental Surveillance

- DOE/1830-T5, A Guide to Reducing Radiation Exposure to As Low As Reasonably Achievable (ALARA)

- 40 CFR 61, "National Emission Standards for Hazardous Air Pollutants"

- 40 CFR 70, "State Operating Permit Programs"

- 40 CFR 265, Subpart AA and B13, "Interim Status Standards for Owners and Operators of Hazardous Waste Treatment, Storage, and Disposal Facilities"

- 40 CFR 302, "Designation, Reportable Quantities, and Notification"

- WAC 173-303-145, "Dangerous Waste Regulations (Spills and Discharges)"

- WAC 246-247, "Radiation Protection--Air Emissions"

\subsection{MEDIA SAMPLED AND ANALYSES PERFORMED}

Procedure protocols for sampling, analysis, data handling, and reporting are specified in WHC (1993). Media include ambient air, surface water, groundwater, external radiation dose, soil, sediment, vegetation, and animals at or near active and inactive facilities and/or waste sites. Parameters monitored include the following, as needed: $\mathrm{pH}$, water temperature, radionuclides, radiation exposure, and hazardous constituents. Animals that are not contaminated, as determined by a field instrument survey, are released to a nonhazardous environment.

\subsection{LOCATIONS}

Samples are collected from known or suspected effluent pathways (e.g., downwind of potential releases, liquid streams, or proximal to release points). To avoid duplication, WHC relies on existing sample locations where PNL has previously established sample sites (e.g., air samplers in the 300 Area). There are 38 air samplers (4 in the 100 Area and 34 in the 200/600 Areas), 35 surface water sample sites (22 in the 100 Area and 13 in the 200/600 Areas), 110 groundwater monitoring wells (20 in the 100 Area, 89 in the 200/600 Areas, and 1 in the 300/400 Areas), 299 external radiation monitor points (182 survey points and 41 thermoluminescent dosimeter (TLD) sites in the 100 Area, 61 TLD sites in the 200/600 Areas, and 15 TLD sites in the $300 / 400$ Areas), 157 soil sample sites (32 in the 100 Area, 110 in the $200 / 600$ Areas, and 15 in the $300 / 400$ Areas), and 95 vegetation sample sites (40 in the 100 Area, 40 in the 200/600 Areas, and 15 in the 300/400 Areas). Animal samples are collected at or near facilities and/or waste sites. Specific locations of sample sites are found in WHC-CM-7-4. 
Surveys to detect surface radiological contamination, scheduled in WHC-SP-0098-5, are conducted near and on liquid waste disposal sites (e.g., cribs, trenches, drains, retention basin perimeters, pond perimeters, and ditch banks), solid waste disposal sites (e.g., burial grounds and trenches), unplanned release sites, tank farm perimeters, stabilized waste disposal sites, roads, and firebreaks in the Operations Areas. There are 391 sites in the Operations Areas (100 in the 100 Area, 273 in the $200 / 600$ Areas, and 18 in the 300/400 Areas) where radiological surveys are conducted.

\subsection{PROGRAM REVIEU}

The near-field (operational environmental) monitoring program will be reviewed at least annually to determine that the appropriate effluents are being monitored and that the monitor locations are in position to best determine potential releases.

\subsection{SAMPLER DESIGN}

Sampler design (e.g., air monitors) will be reviewed at least biannually to determine equipment efficiency and compliance with current EPA and industry (e.g., ANSI and American Society for Testing and Materials [ASTM]) standards.

\subsection{COMMUNICATION}

The operations and engineering contractor and the research and development contractor will compare and communicate results of their respective monitoring programs at least quarterly and as soon as possible under upset conditions.

\subsection{REPORTS}

Results of the near-field operational environmental monitoring program are published in Environmental Releases for Calendar Year 1992, WHC-EP-0527-2 (WHC 1993d), and WHC Operational Environmental Annual Report Calendar Year 1992, WHC-EP-0573-1 (WHC 1993). The radionuclide values in these reports are expressed in curies, or portions thereof, for each radionuclide per unit weight of sample (e.g., picocuries per gram) or in field instrument values (e.g., counts per minute). Values are reported in this manner, rather than $E D E$, which is calculated as the summation of the products of the dose equivalent received by specified tissues of the body and a tissue-specific weighting factor. 


\subsection{QUALITY ASSURANCE}

\subsection{PURPOSE}

The QAPJP (WHC 1992b) describes the QA requirements associated with implementing FEMPs. The plan identifies the FEMP activities and assigns the appropriate QA requirements defined by the WHC Quality Assurance Manual, WHC-CM-4-2 (WHC 1993e). The QAPJP shall be consistent with the requirements in DOE 5700.6C "Quality Assurance" (DOE 1991d). In addition, QA requirements in 40 CFR 61 (EPA 1990a), Appendix B, Method 114 shall be considered when performing monitoring calculations and establishing monitoring systems for airborne emissions.

\subsection{OBJECTIVE}

The plan objective was to improve a documented $Q A$ plan describing QA requirements for facilities implementing the FEMPs.

\subsection{REQUIREMENTS}

A QAPJP (WHC 1992b) has been developed to implement the overall QA program requirements defined by WHC-CM-4-2 (WHC 1993g) and 40 CFR 61, Method 114, Appendix B (EPA 1991a). The QAPjP applies specifically to the field activities, laboratory analyses, and continuous monitoring performed for all FEMPs by Westinghouse Hanford. Plans and procedures referenced in the QAPJP are available for regulatory review upon request by the direction of the Westinghouse Hanford Regulatory Support Manager. A QAPP for Radioactive Airborne Emissions Monitoring was prepared (WHC 1993h) to address the QA elements of 40 CFR 61 and was submitted to the EPA. 


\section{WHC-EP-0470-1}

This page intentionally left blank. 


\subsection{INTERNAL AND EXTERNAL PLAN REVIEN}

The DOE Order 5400.1, General Environmental Protection Program

(DOE 1991a), Chapter IV.4 requires the facility effluent monitoring plan be reviewed annually and updated every three years. The FEMP should be reviewed and updated as necessary after each major change or modification in the facility processes, facility structure, ventilation and liquid collection systems, monitoring equipment, or waste treatment, or for a significant change to the Safety Analysis Reports. In addition, EPA regulations require that records on the results of radioactive airborne emissions monitoring be maintained on-site for five years. Operations management shall maintain records of reports on measurements of stack particulates or other nonradioactive hazardous pollutant emissions for three years.

Facility operators will have to certify on a semiannual basis that no changes in operations that would require new testing have occurred. Although the report is based on the calendar year, the emission limits apply to any period of 12 consecutive months. Westinghouse Hanford Effluent and Emissions Monitoring prepares an annual effluent discharge report for each area on the Hanford Site to cover both airborne and liquid release pathways. In addition, a report on the air emissions and compliance to the NESHAP is prepared by Effluent and Emission Monitoring and submitted to EPA as well as to DOE Headquarters.

Facility management is required to obtain the Effluent and Emission Monitoring function's approval for all changes to the FEMPs, including those generated in the annual review and update. In addition, the FEMP shall be reviewed by $Q A$ and Regulatory Analysis.

Contractor management is responsible for assigning appropriate personnel to perform the reviews, assessments, and approvals as required, and for maintaining this documentation. The DOE may require additional reviews as necessary to ensure program integrity. 
WHC-EP-0470-1

This page intentionally left blank. 


\subsection{COMPLIANCE ASSESSHENT}

A comparison of monitoring/sampling (M/S) system capabilities to regulatory and other requirements was completed to determine which areas are not in compliance. This section summarizes that comparison.

\subsection{COMPLIANCE ASSESSMENT}

\subsubsection{Comparison of Instrument Specifications with Required Standards}

The existing air effluent $M / S$ system of near-isokinetic, continuous sampling with periodic analysis of the resultant samples fully complies with 40 CFR 61, Subpart H (EPA 1991a). Laboratory analysis, quality assurance, and chain-of-custody procedures are adequate to maintain sample accuracy and reliability.

Water effluent, composed of the plant waste water and process condensate, is sampled and analyzed periodically. This technique meets established standards for discharge to the 216-U-14 Ditch. Future discharge to an SALDS will be under a negotiated permit. Comparison to as-yet-to-be-defined discharge criteria, which are the result of the negotiation process, is not possible.

\subsubsection{Comparison of Instrunent Specifications with Monitoring Criteria}

The current air monitoring systems with their capability of continuous, near-isokinetic sampling followed by periodic analyses achieve full compliance with monitoring criteria. Water effluent monitoring criteria of flow, $\mathrm{pH}$, and chemical composition are also fully met by the existing $\mathrm{M} / \mathrm{S}$ system.

\subsubsection{Comparison of Instrument Specifications with Effluent Characteristics}

Existing monitoring equipment for both the air and water effluent streams has the capability to accurately characterize the stream's general parameters such as flow rate, loss of flow, temperature, $\mathrm{pH}$, etc. These general parameters also are appropriate to indicate changes in the effiuents. Laboratory analysis can be selected to characterize essentially any desired effluent parameter. 


\subsubsection{Comparison of Projected Effluent Characteristics with Historical Data}

Historical data used to project effluent characteristics throughout this FEMP were edited so that only data representing conditions during the transition to shutdown were used. Therefore, the projected characteristics are the same as the selected historical effluent data.

\subsubsection{Comparison of Effluent Monitoring Capabilities with Regulatory and Contractor Requirements}

Gaseous effluent monitoring capabilities meet both regulatory and Westinghouse Hanford requirements. At present, the only mitigating control on the $\mathrm{UO}_{3}$ Plant waste water discharge is flow-proportional sampling followed by laboratory analysis with the capability for manual diversion to an alternative retention basin. Therefore, the existing monitoring system is not adequate for detecting releases that exceed the discharge criteria.

\subsection{EXEMPTIONS}

No current or pending exemptions have been identified.

\subsection{SYSTEM UPGRADES REQUIRED FOR COMPLIANCE}

Terminal clean-out and facility stabilization activities are underway which will result in eliminating the waste water stream. After the stream is eliminated, no monitoring will be required. 


\subsection{SUMMARY AND CONCLUSIONS}

There currently are no gaseous or liquid effluents from the $\mathrm{UO}_{3} \mathrm{Plant}$ that require compliance monitoring or sampling. However, it is recommended that effluent streams be sampled, monitored, and reported at regular intervals to ensure continued compliance with all regulatory requirements.

Air samples from the stacks will be analyzed for total Alpha radioactivity, total Beta radioactivity, uranium, ${ }^{90} \mathrm{Sr},{ }^{241} \mathrm{Am}$, plutonium isotopes, and ${ }^{137} \mathrm{Cs}$. The sampling program for air effiuents will be reported annually as described in Section 10.1 of this document.

Liquid effluents will be monitored and sampled to show compliance with applicable regulations and appropriate discharge criteria as described in Section 7.2 of this document. 
WHC-EP-0470-1

This page intentionally left blank. 


\subsection{ATTACHMENTS}

\subsection{REFERENCES}

ANSI, 1969, Guidance to Sampling Airborne Radioactive Material in Nuclear Facilities, ANSI N13.1-1969, American National Standards Institute.

Beres, D. A., 1990, The Clean Air Act Assessment Package - 1988 (CAP-88). $A$ Dose and Risk Assessment Methodology for Radionuclide Emissions to Air, Volumes 1-3, U.S. Environmental Protection Agency, Washington, D.C.

Caymman, J.W., 1980, 200 Area Stack Sampler-Monitor Systems Upgrade: Generic Systems Applications, RHO-CD-1092, Rockwell Hanford Operations, Richland, Washington

Caymman, J.W., 1984, Fiscal Year 1985200 Area Stack Sampler/Monitor Systems Upgrade, SD-WM-CR-016, Rockwe11 Hanford Operations, Richland, Washington

Clean Water Act, as amended, Public Law 95-217, 92 Stat. 1566, 33 USC 1251.

Comprehensive Environmental Response, Compensation and Liability Act of 1980 , as amended, Public Law 96-510, 94 Stat. 2767, 42 USC 9601 et seq.

Crane, A. F., 1991, Functional Design Criteria for the 242A/PUREX Plant Condensate Treatment Facility, WHC-SD-CO18H-FDC-001, Westinghouse Hanford Company, Richland, Washington, June 3, 1991.

DOE, 1983, Environmental Protection, Safety and Health Protection Information Reporting Requirements, DOE Order 5484.1, U.S. Department of Energy, Washington D.C., September 26, 1983.

DOE, 1988a, Internal Dose Conversion Factors for Calculation of Dose to the Public, DOE/EH-0071, U.S. Department of Energy/Environmental Health, Washington, D.C., July 1988.

DOE, 1988b, Radioactive Waste Management, DOE Order 5820.2A, U.S. Department of Energy, Washington, D.C., September 26, 1988.

DOE, 1990a, Radiation Protection of the Public and the Environment, DOE Order 5400.5 , U.S. Department of Energy, Washington D.C., February 8, 1990.

DOE, 1991a, General Environmental Protection Program, DOE Order 5400.1, U.S. Department of Energy, Washington D.C.

DOE, 1991b, External Dose Conversion Factors for Calculation of Dose to the Public, DOE/EH-0070, U.S. Department of Energy/Environmental Health, Washington, D.C., July 1988.

DOE, 1991c, Environmental Regulatory Guide for Radiological Effluent Monitoring and Environmental Surveillance, DOE/EH-0173T, U.S. Department of Energy/Environmental Health, Washington, D.C. 
DOE, 1991d, Quality Assurance, DOE Order 5700.6B, U.S. Department of Energy, Washington D.C., September 23, 1986.

DOE, 1993a, Radionuclide Air Emissions Report for the Hanford Site Calendar Year 1992, DOE/RL-93-36, U.S. Department of Energy, Richland, Washington

DOE, 1993b, Occurrence Reporting and Processing of Operations Information, DOE Order 5000.3B, U.S. Department of Energy, Washington D.C.

EPA, 1980a, Prevention of Significant Deterioration Permit for Discharge of $\mathrm{NO}_{\mathrm{X}}$ from PUREX $/ \mathrm{UO}_{3}$ Plants, PSD-X80-14, U.S. Environmental Protection agêncy, Washingtơh, D.C.

EPA, 1988a, Standards Applicable to Generators of Hazardous Waste, Title 40, Code of Federal Regulations, Part 262, U.S. Environmental Protection Agency, Washington, D.C.

EPA, 1988b, Standards for Owners and Operators of Hazardous Waste Treatment Storage, and Disposal Facilities, Title 40, Code of Federal Regulations, Part 264, as amended, U.S. Environmental Protection Agency, Washington, D.C.

EPA, 1988c, Standards for Owners and Operators of Hazardous Waste Treatment, Storage, and Disposal Facilities, Title 40, Code of Federal Regulations, Part 265, as amended, U.S. Environmental Protection Agency, Washington, D.C.

EPA, 1989a, Identification and Listing of Hazardous Waste, Title 40 , Code of Federal Regulations, Part 261, U.S. Environmental Protection Agency, Washington, D.C.

EPA, 1990a, Quality Assurance Methods, Title 40, Code of Federal Regulations, Part 60, U.S. Environmental Protection Agency, Washington, D.C.

EPA, 1991a, National Emission Standards for Hazardous Air Pollutants, Title 40, Code of Federal Regulations Part 61, U.S. Environmental Protection Agency, Washington, D.C.

EPA, 1991b, Designation, Reportable Quantities and Notification, Title 40 , Code of Federal Regulations, Part 302, as amended, U.S. Environmental Protection Agency, Washington, D.C.

EPA, 1991c, Approval and Promulgation of Implementation Plans, 40 Code of Federal Regulations, Part 52, U.S. Environmental Protection Agency, Washington, D.C.

EPA, 1991d, National Interim Primary Drinking Regulations, 40 Code of Federal Regulations Part 141, U.S. Environmental Protection Agency, Washington, D.C.

EPA, 199le, Effluent Guidelines and Standards, 40 Code of Federal Regulations Part 401, U.S. Protection Agency, Washington D.C. 
Moore, R. E., C. F. Baes III, L. M. McDowel1-Boyer, A. P. Watson, F. O. Hoffman, J. C. Pleasant, and C. W. Miller, June, 1979, AIRDOS-EPA: A Computerized Methodology for Estimating Environmental Concentrations and Dose to Man from Airborne Releases of Radionuclides, ORNL-5532, Oak Ridge National Laboratory, Oak Ridge, Tennessee.

PNL, 1989, Memorandum of Understanding, Pacific Northwest Laboratory and Westinghouse Hanford Company, Richland, Washington.

RCRA, 1976, Resource Conservation and Recovery Act of 1976, as amended, Public Law 94-580, 90 Stat. 2795, 42 USC 6901, et seq.

RCW, 1945, Water Pollution Control Act of 1945, as amended, Revised Code of Washington 90.48 .

RHO, 1986a, Radioactivity in Gaseous Waste Discharged from the Separations Facilities during 1986, RHO-HS-SR-86-2 4QGASP, Rockwell Hanford Operations, Richland, Washington.

RHO, 1986b, Radioactive Liquid Wastes Discharged to Ground in 200 Areas during 1986, RHO-HS-SR-86-3 4QLIQP, Rockwell Hanford Operations, Richland, Washington.

Safe Drinking Water Act, as amended, Public Law 93-523, 42 USC 300f, et seq.

Slade, D. H., ed., July, 1968, Meteorology and Atomic Energy, U.S. Atomic Energy Commission/Division of Reactor Development and Technology.

WAC, 1987, Water Quality Standards for Groundwaters of the State of Washington, WAC-173-200, Washington Administrative Code, 01ympia, Washington.

WAC, 1991a, Dangerous Waste Regulations, Washington Administrative Code 173-303, Washington State Department of Ecology, Olympia, Washington.

WAC, 1991b, Radiation Protection Air Emissions, Washington Administrative Code, 246-480, Washington State Department of Ecology, 0lympia, Washington

WAC, 1991c, Washington State Ambient Air Quality Standard and Emission Limits for Radionuclides, Washington Administrative Code 173-480, Washington State Department of Ecology, Olympia, Washington.

WAC, 1991d, Washington Administrative Code 173-216, Washington State Department of Ecology, Olympia, Washington

WHC, 1982, Generic Stack Sampler/Monitor Flow Diagram, H-2-92486, Westinghouse Hanford Company, Richland, Washington.

WHC, 1987, Effluent Releases and Solid Waste Management Report for 1987: $200 / 600 / 1100$ Areas, WHC-EP-0141, Westinghouse Hanford Company, Richland, Washington. 
WHC, 1988, Westinghouse Hanford Company Environmental Surveill ance Annual Report 200/600 Areas Calendar Year 1987, WHC-EP-0145, R. E. Elder, G. W. Egert, A. R. Johnson, Westinghouse Hanford Company, Richland, Washington, April 1988.

WHC, 1989a, Effluent Monitoring Plan for $\mathrm{UO}_{3}$ Plant Gaseous Effluents, SD-CP-EMP-003, Rev. 1, West inghouse Hanford Company, Richland, Washington.

WHC, 1989b, Quality Assurance Progran Plan for the Analysis of Highly Radioactive Mixed Waste Samples in Support of Environmental Activities on the Hanford Site, Westinghouse Hanford Company, Richland, Washington.

WHC, 1989c, Westinghouse Hanford Company Effluent Discharges and Solid Waste Management Report for Calendar Year 1988: 200 Areas/600 Areas, WHC-EP-0141-1, Westinghouse Hanford Company, Richland, Washington.

WHC, 1989d, Identifying and Resolving Unreviewed Safety Questions, WHC-CM-1-3, West inghouse Hanford Company, Richland, Washington.

WHC, 1989e, Emergency Plan, WHC-CM-4-1, Westinghouse Hanford Company, Richland, Washington.

WHC, 1990a, Stream Specific Reports, WHC-EP-0342, Addenda 7 and 19, Westinghouse Hanford Company, Richland, Washington.

WHC, 1990b, Radiological Design, WHC-4-9, Westinghouse Hanford Company, Richland, Washington.

WHC, 1990c, Facility Effluent Monitoring Plan Determinations for the 200 Area Facilities, WHC-EP-0440, Westinghouse Hanford Company, Richland, Washington.

WHC, 1990d, Quality Assurance Project Plan for the Chemical Analysis of Environmental Samples, WHC-SD-CP-QAPP-0031, Westinghouse Hanford Company, Richland, Washington.

WHC, 1990e, Westinghouse Hanford Company Effluent Discharges and Solid Waste Management Report for Calendar Year 1989: 200 Areas/600 Areas, WHC-EP-0141-2, Westinghouse Hanford Company, Richland, Washington.

WHC, 1991a, IEFD Liquid Effluent System, H-2-97874, Westinghouse Hanford Company, Richland, Washington.

WHC, 1991b, Liquid Effluent Sampling Quality Assurance Project Plan, WHC-SD-WM-QAPP-011, Westinghouse, Hanford.

WHC, 1991C, Management Plan for Facility Effluent Monitoring Plan Activities, WHC-EP-0491, Westinghouse Hanford Company, Richland, Washington.

WHC, 1991d, $\mathrm{UO}_{3}$ Liquid Effluent Monitoring Plan, SD-CP-EMP-005, Rev. 1, Westingholuse Hanford Company, Richland, Washington. 
WHC, 199le, Facility Effluent Monitoring Plan for the 222-S Laboratory, WHC-EP-0480, Westinghouse Hanford Company, Richland, Washington, November 1991 .

WHC, 1992a, Operational Environmental Monitoring, as amended, WHC-CM-7-4, Westinghouse Hanford Company, Richland, Washington.

WHC, 1992b, Quality Assurance Project Plan for the Facility Effluent Monitoring Plan Activities, WHC-EP-0446-01, Westinghouse Hanford Company, Richland, Washington.

WHC, 1992C, Environmental Releases for Calendar Year 1990, WHC-EP-0527, Westinghouse Hanford Company, Richland, Washington.

WHC, 1992d, Environmental Releases for Calendar Year 1991, WHC-EP-0527-1, Westinghouse Hanford Company, Richland, Washington.

WHC, 1992e, Westinghouse Hanford Company Environmental Surveillance Annual Report 200/600 Area Calendar Year 1990, WHC-EP-0145, Westinghouse Hanford Company, Richland, Washington.

WHC, 1993a, Environmental Releases for Calendar Year 1992, WHC-EP-0527-2, Westinghouse Hanford Company, Richland, Washington.

WHC, 1993b, Environmeıtal Compliance Manual, WHC-CM-7-5, Rev. 2, Westinghouse Hanford Company, Richland, Washington.

WHC, 1993c, Environmental Releases for Calendar Year 1992, WHC-EP-0527-2, Westinghouse Hanford Company, Richland, Washington.

WHC, 1993d, Analytical Chemistry Services Laboratories Operating Instructions, WHC-CM-5-4, Westinghouse Hanford Company, Richland, Washington.

WHC, 1993e, PUREX/UO 3 Plant Administration, WHC-CM-5-9, Westinghouse Hanford Company, Richland, Washington, March, 1990.

WHC, 1993f, Analytical Chemistry Services Laboratories Quality Assurance Plan, SD-CP-QAPP-001, G. B. Svancara and S. S. Moss, Westinghouse Hanford Company, Richland, Washington.

WHC, 1993g, Quality Assurance Manual, WHC-CM-4-2, Westinghouse Hanford Company, Richland, Washington.

WHC, 1993h, Quality Assurance Plan for Radionuclide Airborne Emissions Monitoring, WHC-EP-0536, Westinghouse Hanford Company, Richland, Washington.

WHC, 1993i, Operational Environmental Monitoring, WHC-CM-7-4, Westinghouse Hanford Company, Richland, Washington. 